Portland State University

PDXScholar

Summer 8-13-2014

\title{
Investigating the Link Between Surface Water and Groundwater in the Tule Lake Subbasin, Oregon and California
}

Esther Maria Pischel

Portland State University

Follow this and additional works at: https://pdxscholar.library.pdx.edu/open_access_etds

Part of the Geology Commons, and the Water Resource Management Commons Let us know how access to this document benefits you.

\section{Recommended Citation}

Pischel, Esther Maria, "Investigating the Link Between Surface Water and Groundwater in the Tule Lake Subbasin, Oregon and California" (2014). Dissertations and Theses. Paper 1941.

https://doi.org/10.15760/etd.1940

This Thesis is brought to you for free and open access. It has been accepted for inclusion in Dissertations and Theses by an authorized administrator of PDXScholar. Please contact us if we can make this document more accessible: pdxscholar@pdx.edu. 
Investigating the Link Between Surface Water and Groundwater in the Tule Lake

Subbasin, Oregon and California

by

Esther Maria Pischel

A thesis in partial fulfillment of the requirements for the degree of

\author{
Master of Science \\ in \\ Geology
}

Thesis Committee:

Robert B. Perkins, Chair

Marshall W. Gannett

Michael L. Cummings

Portland State University

2014 


\begin{abstract}
Water allocation in the upper Klamath Basin of Oregon and California has been challenging. Irrigators have increasingly turned to groundwater to make up for surface water shortages because of shifts in allocation toward in-stream flows for Endangered Species Act listed fishes. The largest increase in groundwater pumping has been in and around the Bureau of Reclamation's Klamath Irrigation Project, which includes the Tule Lake subbasin in the southern part of the upper Klamath Basin. Previous groundwater flow model simulations indicate that water level declines from pumping may result in decreased flow to agricultural drains in the Tule Lake subbasin. Agricultural drains on the Klamath Project are an important source of water for downstream irrigators and for the Tule Lake and Lower Klamath Lake National Wildlife Refuges. To better assess the impact of increased pumping on drain flow and on the water balance of the groundwater system, flow data from agricultural drains were evaluated to investigate the changes that have taken place in groundwater discharge to drains since pumping volumes increased. Additionally, a fine-grid groundwater model of the Tule Lake subbasin was developed based on the existing regional flow model. The fine-grid model has sufficient vertical and horizontal resolution to simulate vertical head gradients, takes advantage of time-series data from 38 observation wells for model calibration, and allows agricultural drains to be more explicitly represented. Results of the drain flow analysis show that the groundwater discharge to agricultural drains has decreased by approximately 4000 hectare-meters from the 1997-2000 average discharge. Most of this decrease takes place in the northern and southeastern portions of the subbasin. Results of the groundwater model show that
\end{abstract}


the initial source of water to wells is groundwater storage. By 2006 , approximately $56 \%$ of the water from wells is sourced from agricultural drains. 


\section{Dedication}

This thesis is dedicated to my Mom and Dad. Thank you for lighting my path. 


\section{Acknowledgments}

I would like to acknowledge U.S. Bureau of Reclamation and the U.S. Fish and Wildlife Service for providing funding for this project.

I would also like to acknowledge Brad Kirby, Assistant to the Manager of Tulelake Irrigation District and Mark Stuntebeck, Manager of Klamath Irrigation District, for providing valuable data and insight during the course of this project.

Finally, I'd like to acknowledge those I've worked with in the Geology Department of Portland State University and the United States Geological Survey, particularly Ben Perkins, Michael Cummings, and Marshall Gannett. A fledgling geoscientist couldn't ask for better mentors. Thank you. 


\section{Table of Contents}

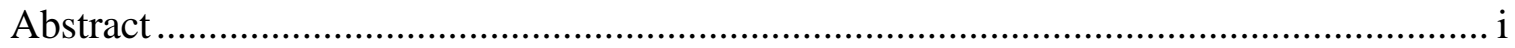

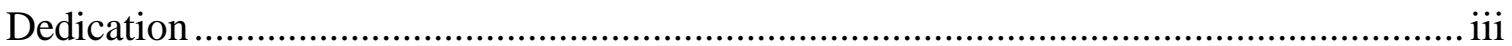

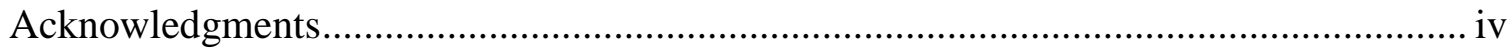

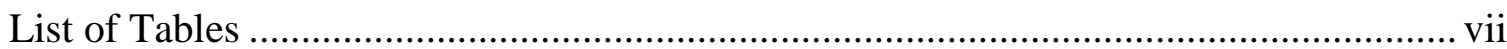

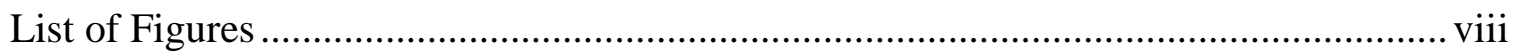

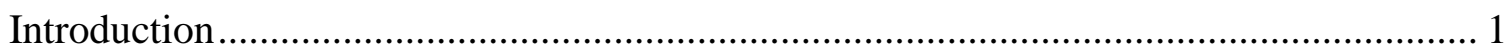

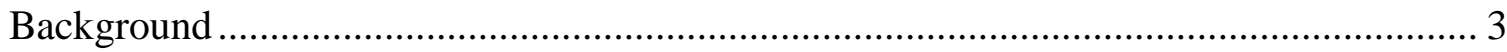

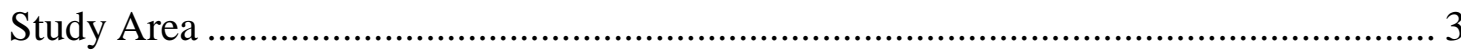

Increases in Groundwater Pumping ................................................................... 11

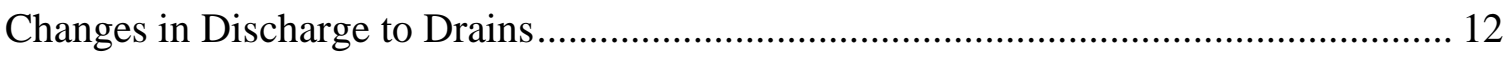

Sources of Water to Wells .............................................................................. 13

Changes in Hydraulic Head and Flow ................................................................... 14

USGS Regional Model .................................................................................... 16

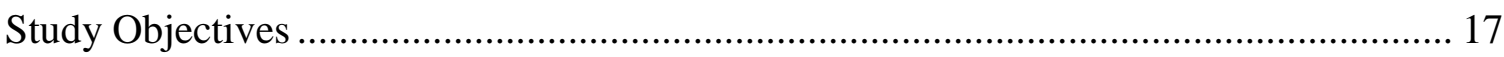

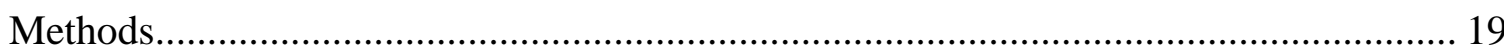

Objective 1: Hydrologic Budget for Drains ............................................................ 19

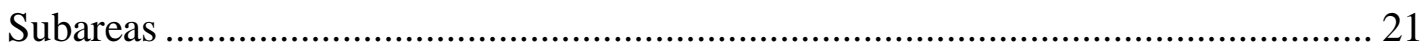

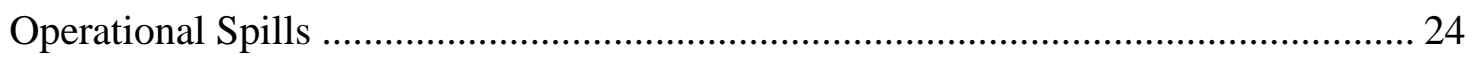

Objective 2: Groundwater Model ........................................................................ 25

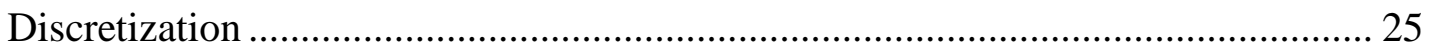

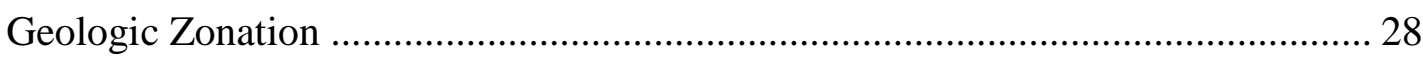

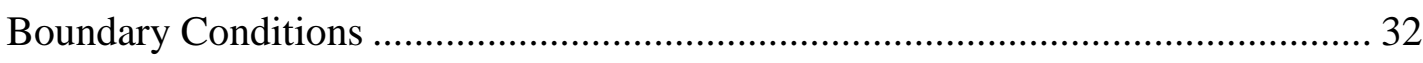

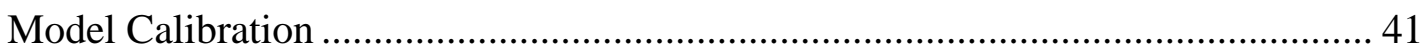

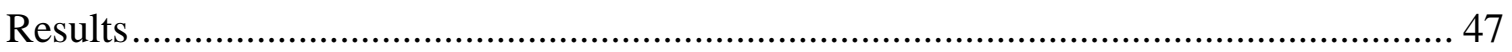

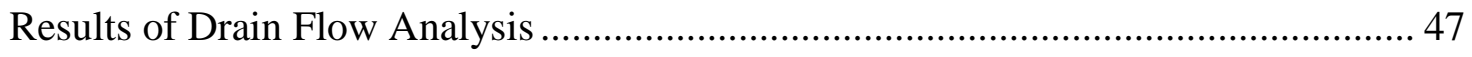

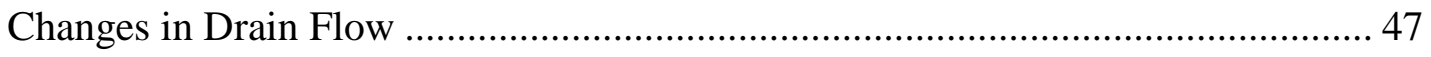

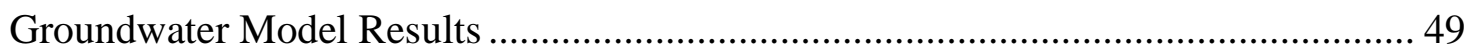

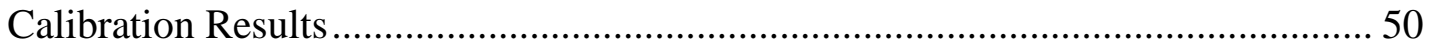

Simulated Hydrologic Budget and Sources of Water to Wells............................... 61

Influence of Interbasin Groundwater Flow ....................................................... 70

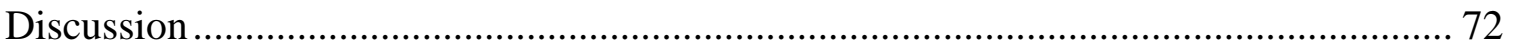

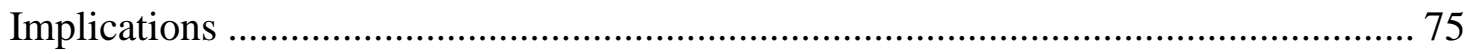




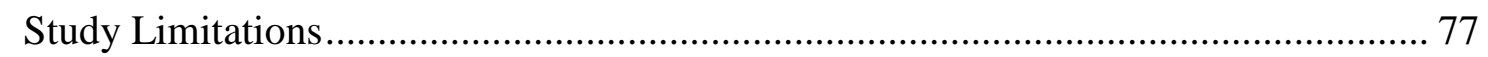

Uncertainty in Drain Flow Analysis ............................................................... 78

Uncertainty in Groundwater Model ................................................................... 78

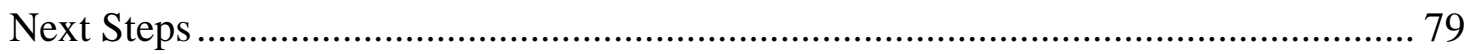

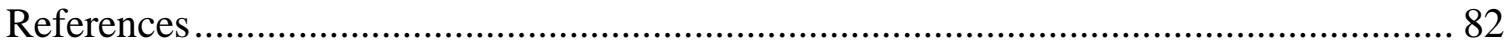

Appendix A: Simulated and Observed Hydraulic Head for All Observation Wells ........ 84

Appendix B: Supplemental Files ............................................................................ 104 


\section{List of Tables}

Table 1. Layer thicknesses for the Tule Lake subbasin model.......................................28

Table 2. Observation wells in the Tule Lake subbasin model........................................46

Table 3. Calibration parameters and their final values for the Tule Lake subbasin, Oregon

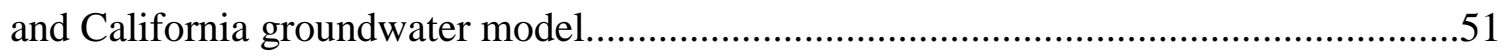

Table 4. Cumulative change in Tule Lake model volumetric budget.............................65 


\section{List of Figures}

Figure 1. Study area. Tule Lake subbasin is outlined by box. Water bodies, streams, and the canal and drain system are in blue. Major roads are denoted by black lines

Figure 2. Example of a typical sediment-filled subbasin in the upper Klamath Basin. Subbasins are typically filled with fine-grained sediment and floored with lavas with moderate to high permeability. It is from the lavas that large-scale pumping takes place (from Gannett et al, 2007).

Figure 3. Agricultural drain in the Tule Lake subbasin. Photo by Ben Perkins. 8

Figure 4. Schematic of inflows/outflows to Tule Lake subbasin, shown as the large box in this figure. The boundary between the Klamath Irrigation District (KID) and the Tulelake Irrigation District (TID) is shown in the northern portion of the subbasin as a dashed line. TLNWR = Tule Lake National Wildlife Refuge, and LKNWR = Lower Klamath National Wildlife Refuge. 10

Figure 5. D Pump pumpage in hectare-meters, from 1961 to 2011. Data point for 2001 has been removed because it was an anomalous year and does not represent average conditions.

Figure 6. Hydrographs of five wells within the same geographic location in the Tule Lake subbasin. Hydraulic heads have decreased more rapidly in deeper zones over the period of record, which has increased the vertical hydraulic gradient.

Figure 7. Example of a drain pump in the TID system. Shown here is Pump A............. 20

Figure 8. Subareas and drain pumps used in analysis of TID drain flow. ...................... 23

Figure 9. Tule Lake subbasin model boundaries and grid cell types............................. 27

Figure 10. Geologic zonation of the Tule Lake groundwater model. The Tule Lake sumps, shown in the index map in the lower right, are shown in the first layer as a spatial reference. Gray cells are inactive model cells; other colors represent the geology represented in the model. Qs: Quaternary sediments; Qv: Quaternary volcanics; Tsy: Tertiary sediments of younger basins; Tsv: Tertiary sediments and volcanics. The depth interval, in meters, is shown below each layer.

Figure 11. Cells with reduced recharge due to lower density of canals. Cells highlighted have a recharge value of $25 \%$ the original value.

Figure 12. Locations of observation wells for the Tule Lake subbasin model. Wells are

numbered with the identification number used in the model. 
Figure 13. Yearly volume pumped from pumps integrating the North TID/KID subarea, in hectare-meters. Reference line shows the average 1997-2000 pumping. Data for 2001 and 2010 were omitted because of the effects of severely-curtailed surface-water deliveries.

Figure 14. Yearly volume pumped from pumps integrating the Copic Bay subarea, in hectare-meters. Reference line shows average 1997-2000 pumping. Note the scale change between this and plots for the other subareas. Data for 2001 and 2010 were omitted because of the effects of severely-curtailed surface-water deliveries. 48

Figure 15. Yearly volume pumped from pumps integrating the Lease Lands subarea, in hectare-meters. Reference line shows average 1997-2000 pumping. Data for 2001 and 2010 were omitted because of the effects of severely-curtailed surface-water deliveries. 49

Figure 16. Weighted residuals vs. weighted simulated hydraulic head values 55

Figure 17 (A - I). Observed and simulated hydraulic head plots for a selection of model observation wells. Observed values are shown in solid red, and simulated values are

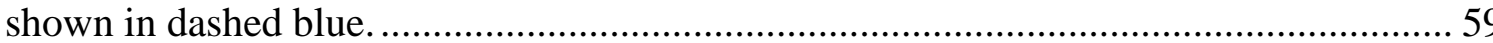

Figure 18. Water levels in USGS observation well 430837121473201, 28.00S/08.00E17DBC01.

Figure 19. Water levels in USGS Observation well 430055121401501, 29.00S/09.00E32DBA01

Figure 20. Instantaneous rates of budget components at the end of each stress period of the Tule Lake model.

Figure 21. Cumulative change in volume of selected budget components of the Tule Lake model.

Figure 22. Loss of discharge to drains, in hectare-meters per year, calculated as the difference between the discharge to drains in 2000 and discharge in subsequent years. Blue line is drain loss with 2001 and 2010 data included; red line is the drain loss plot with an averaged 2001 data point and no 2010 data point. 2001 and 2010 are anomalous years; spikes in drain loss those years reflect a marked decrease in recharge as well as increased pumping. The full, integrated effect of pumping in drain flow is shown more clearly in the slow rise of the red plot. The maximum loss in drain flow occurs in 2006, when the impact to drains is 1,852 hectare-meters, which is $57 \%$ of the average annual 2001-2006 supplemental pumping of 3215 hectare-meters per year.

Figure 23. Observed and simulated loss in flow to drains. Observed loss in flow to drains is calculated from the total drain loss from all 3 subareas of the drain flow analysis. To calculate drain flow loss, the observed drain flow in 2000 was taken to be the base, prepumping condition, and the drain flow for each subsequent year (up to 2010) was 
subtracted from the 2000 value. Note: in 2002 the drain flow loss is negative; this indicates that the 2002 drain flow was higher than it was in 2000.

Figure 24. Modeled spatial distribution of impacts to drains, in hectare-meters per year, calculated as the discharge to drains in 2006 (the year of maximum drain impact) subtracted from the discharge to drains in 2000. Since discharge to the drains represents a loss of water from the aquifer, the discharge volumes used in the calculation are negative. 
Introduction

The upper Klamath Basin, located in southern Oregon and northern California (Figure 1), is an area in which the allocation of water between agriculture and aquatic wildlife has been challenging for resource managers. In 2001, drought conditions produced a crisis-level water shortage. In response, nearly all of the available water in the Upper Klamath Basin was reallocated in order to maintain water levels in Upper Klamath Lake and flows in the Klamath River in order to protect the threatened Coho salmon and the endangered Lost River and shortnose suckers (National Research Council, 2004). In response to this reallocation of water, irrigators have increasingly turned to groundwater to make up for the shortages in surface water availability. In the past decade, many new wells have been drilled in the basin, resulting in a significant increase in groundwater pumping. The largest increase is in and around the Bureau of Reclamation's Klamath Irrigation Project (hereafter, "Project") which includes the Tule Lake subbasin, located in the southern portion of the Upper Klamath Basin (Gannett et al., 2007).

Groundwater pumping has resulted in water level declines in many wells of all depths in and around the centers of pumping. These declines reflect a change in the distribution of hydraulic head which affects directions and rates of groundwater flow. Results of U.S. Geological Survey (USGS) groundwater modeling efforts (Gannett et al., 2012), analysis of monitoring well data, and hydrologic budget information from the Bureau of Reclamation and irrigation districts that operate in the Tule Lake subbasin indicate that pumping-related head changes may be resulting in decreased flow to 
agricultural drains in parts of the Project area. The lowering of hydraulic heads in aquifers beneath basin-filling sediments may be inducing increased downward flow of shallow groundwater, diminishing lateral flow toward drains. Diminished shallow groundwater discharge to agricultural drains has potential implications for Project operations and for water supplies to the Tule Lake and Lower Klamath National Wildlife Refuges.

The purpose of this investigation is to develop a more quantitative understanding of the connection between volcanic aquifers and groundwater in overlying sedimentary deposits in and around the Tule Lake subbasin of the Upper Klamath Basin. As part of that goal, flow data from irrigation districts that serve the Tule Lake subbasin have been analyzed to understand changes that have taken place in the water balance of the subbasin. Additionally, to synthesize knowledge about the groundwater hydrology of the subbasin, a fine-grid numerical model of the Tule Lake subbasin has been developed to aid in the quantitative understanding of the connection between pumping and drain discharge, in order to understand the degree to which increased groundwater pumping may be affecting flow in drains. 


\section{Background}

Study Area

The Tule Lake subbasin is located in the southeast portion of the Upper Klamath Basin, and straddles the Oregon-California border (Figure 1). Prior to development, the Tule Lake subbasin contained a large lake with an area of up to 38,800 hectares $(96,000$ acres) fringed by extensive wetlands. In 1912 a canal and dam were constructed to divert the flow of the Lost River to the Klamath River, cutting off inflow to Tule Lake (LaRue, 1922). As a consequence, the lake has been mostly drained, and much of the Tule Lake subbasin is now under cultivation. 


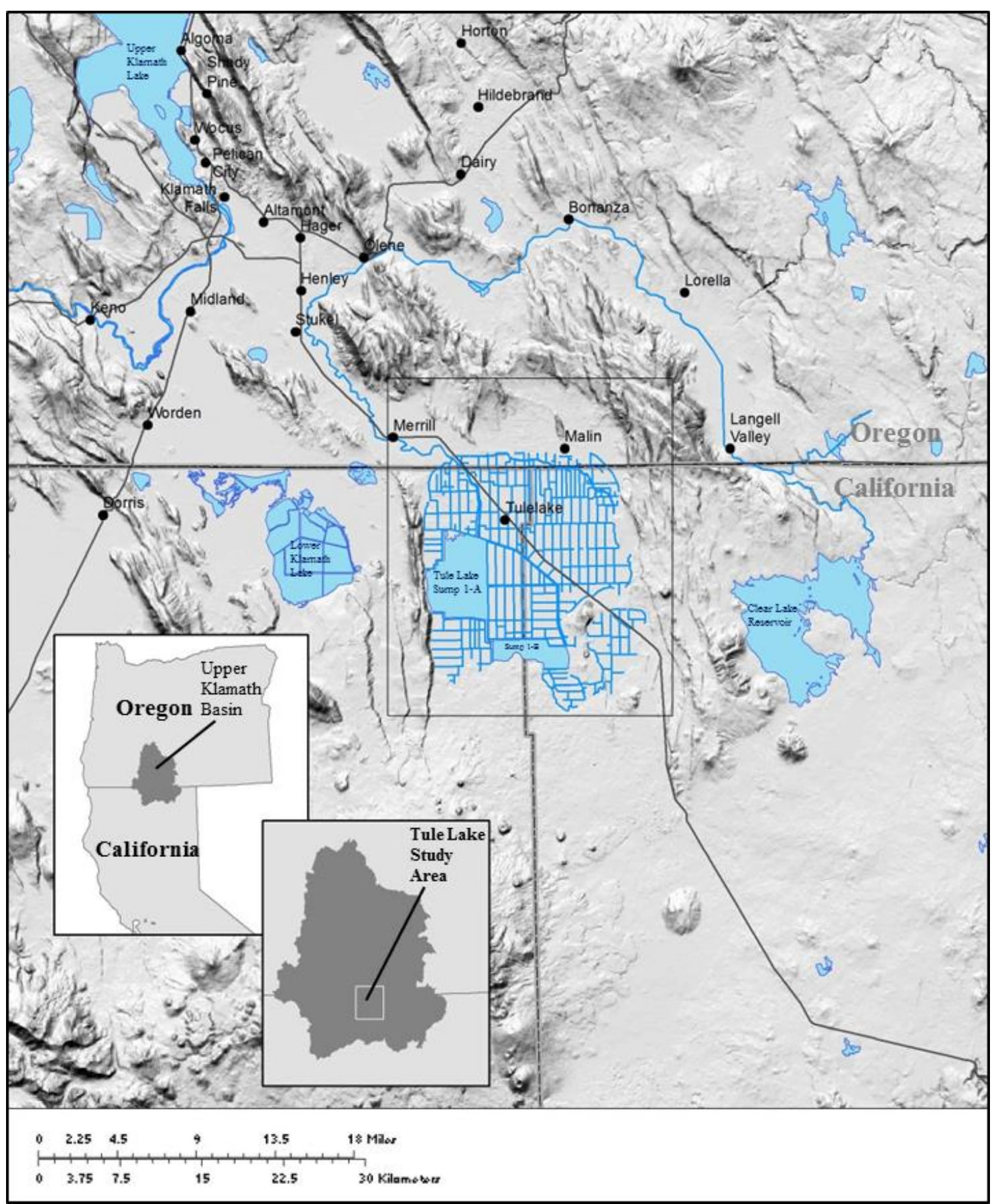

Figure 1. Study area. Tule Lake subbasin is outlined by box. Water bodies, streams, and the canal and drain system are in blue. Major roads are denoted by black lines 
The Tule Lake subbasin is a structural basin created by faulting of middle to late Tertiary basaltic and andesitic lava flows and vent deposits. Interspersed with the lava flows and vent deposits are fine-grained continental sedimentary deposits including bedded diatomite, mudstone, siltstone, and sandstone (Gannett et al., 2007). Collectively, these deposits form the most widely developed aquifer in the Tule Lake subbasin. Throughout this report these deposits will be collectively referred to as the volcanic aquifer. The structural basin has been filled with interbedded lacustrine sediment and volcanic tephra to depths locally exceeding 550 meters (1800 feet) (Adam et al., 1990). Groundwater is extracted from both the sediment and underlying volcanic aquifer. Wells installed in the sediment have modest yields because of low to moderate permeability, and produce water adequate for domestic and stock use. Wells in the underlying volcanic aquifer, which is highly permeable, generally produce large volumes of water adequate for irrigation. At the southern edge of the Tule Lake subbasin there are Quaternary andesitic and basaltic lavas erupted from Medicine Lake volcano. These deposits are generally highly permeable (Gannett et al., 2007). 


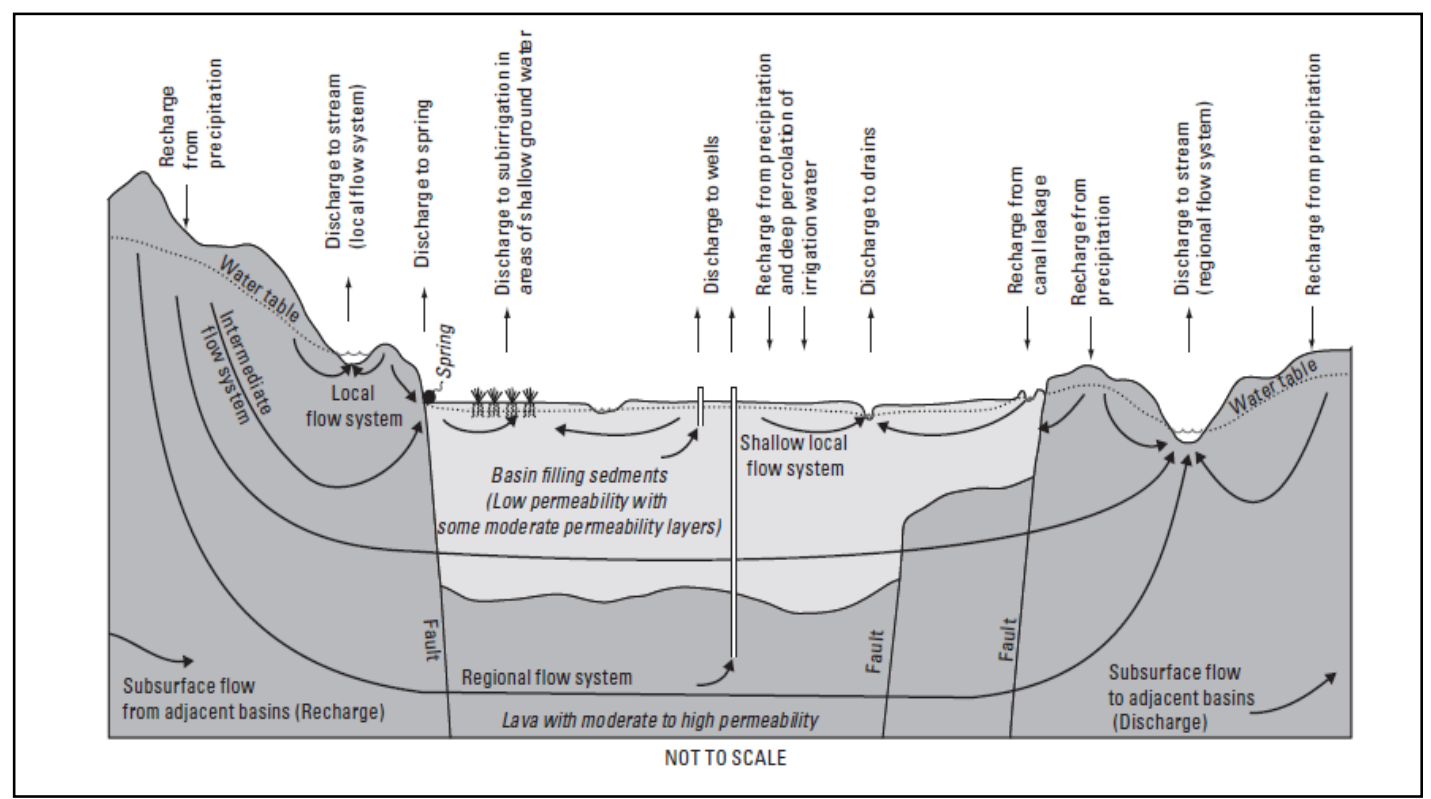

Figure 2. Example of a typical sediment-filled subbasin in the upper Klamath Basin. Subbasins are typically filled with fine-grained sediment and floored with lavas with moderate to high permeability. It is from the lavas that large-scale pumping takes place (from Gannett et al, 2007).

Much of the Tule Lake subbasin is now within the U.S. Bureau of Reclamation Klamath Project, which is irrigated with water primarily from Upper Klamath Lake.

Water diverted from Upper Klamath Lake is transferred through a series of canals and applied to crops in large areas of the lower Lost River drainage and Tule Lake subbasin. The Tule Lake subbasin includes the Klamath Irrigation District (KID) and Tulelake Irrigation District (TID). A certain amount of the diverted water is lost through canal leakage during transmission and through deep percolation in fields, recharging the shallow parts of the groundwater system. In general the land gently slopes toward the Tule Lake sumps, the ultimate collector of excess irrigation water in the subbasin.

In addition to supply canals, the Project area is crisscrossed by an array of agricultural drains. Agricultural drains are in place to accumulate excess water that has 
percolated to the shallow subsurface. If this water were not collected in the drains and pumped out, the subbasin would quickly become waterlogged and be unsuitable for farming. Drains in the Project area are generally large open ditches extending roughly 3 meters (10 feet) below land surface, and commonly extending laterally hundreds of meters (Figure 3).

In general, there are two pathways for water to enter the drain system: via the groundwater system or via some sort of surface flow. Shallow groundwater that may enter the drains begins either as precipitation, as irrigation water applied to crops, or as water that seeped from the canal system. Water applied to crops generally either returns to the atmosphere through evapotranspiration or percolates beneath the root zone and recharges the shallow parts of the groundwater system. Water from percolation or from canal leakage that makes it to the groundwater system either flows laterally and discharges to the network of agricultural drains that blanket the area, or vertically downward through basin-filling sediments to the underlying volcanic aquifer. The connection between the shallow and deep aquifers is evidenced by deep wells whose water levels respond to the initiation of irrigation season on the Project (Palmer et al., 2006; Gannett et al., 2007). Isotopic analysis of aquifers feeding deep irrigation wells in the Tule Lake subbasin also suggest a hydraulic connection between the shallow and deep aquifer (Palmer et al., 2006).Water applied to crops can also contribute water to the drain system via over-land flow or interflow. 


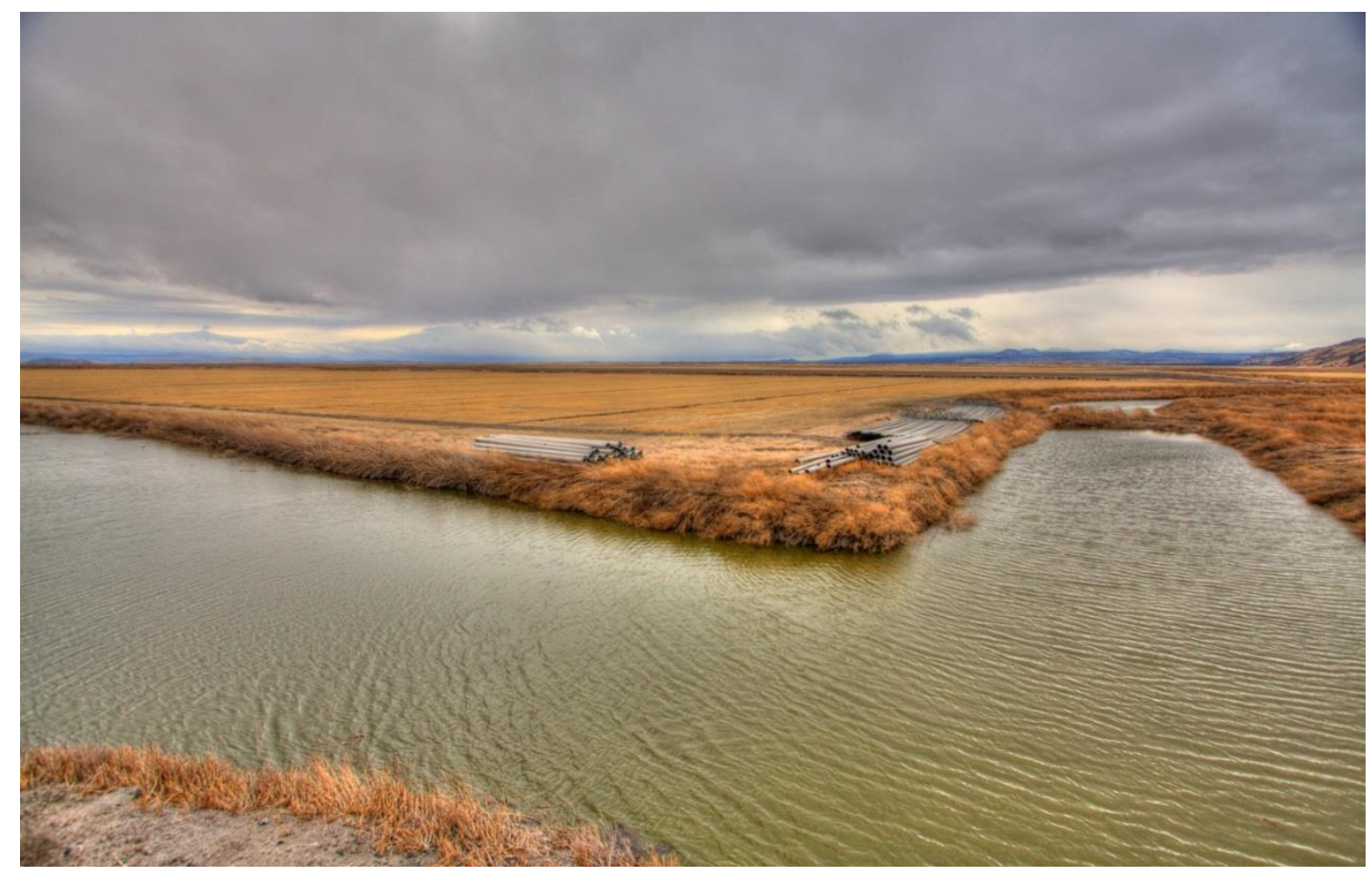

Figure 3. Agricultural drain in the Tule Lake subbasin. Photo by Ben Perkins.

Another source of water to agricultural drains is operational spill, which occurs in the transition between KID which irrigates the northern portion of the Tule Lake subbasin that lies within Oregon, and TID which irrigates within the remainder of the subbasin. KID must keep more water in its irrigation canals in order to provide a buffer for the unpredictable needs of water users and in order to supply users at the end of its system, since irrigation deliveries take up to 24 hours to reach those users. When there is extra water in the canal at the end of the system, it is necessary to spill it to the drain system for use by the downstream irrigation district, TID. This spill of excess irrigation water is termed “operational spill." KID spills its excess water to the TID's drain system at its northern edge. 
Water that flows into the drain system, whether it is groundwater or surface water, is either pumped back up into the distribution canal system, or flows to the Tule Lake sump system, the remnant of Tule Lake. The Tule Lake sumps are located in the southern and western parts of the basin. Since 1942, water from the sump has been pumped via Pumping Plant D (Plant D) through a tunnel in Sheepy Ridge west into the Lower Klamath Lake subbasin (Gannett et al., 2007). Large parts of TID rely on drain flows for their irrigation supply. In addition, water from drains that ends up in the Tule Lake sump is a critical part of the water supply for the Tule Lake and Lower Klamath Lake National Wildlife Refuges (Risley and Gannett, 2006). Consequently, a change in shallow groundwater discharge to agricultural drains has potential consequences for the irrigation project and for water management on the refuge system. 


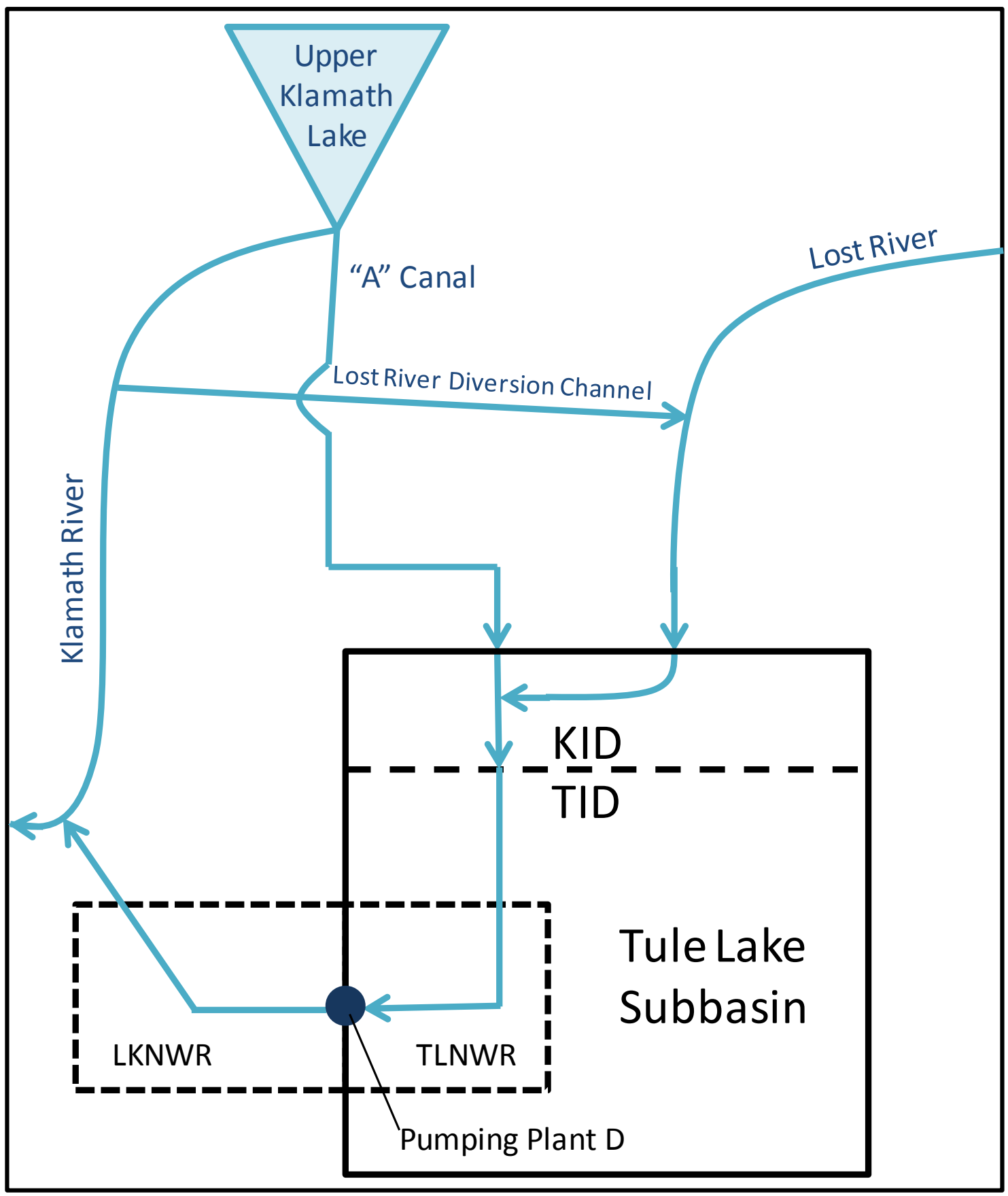

Figure 4. Schematic of inflows/outflows to Tule Lake subbasin, shown as the large box in this figure. The boundary between the Klamath Irrigation District (KID) and the Tulelake Irrigation District (TID) is shown in the northern portion of the subbasin as a dashed line. TLNWR = Tule Lake National Wildlife Refuge, and LKNWR = Lower Klamath National Wildlife Refuge. 
Increases in Groundwater Pumping

Since 2001, groundwater pumping has increased in the Upper Klamath Basin in response to changes in surface-water management and to a series of consecutive drierthan-average years. Much of this increase was related to government-funded supplemental pumping programs, including a pilot water bank mandated by the National Oceanic and Atmospheric Administration's 2002 Biologic Opinion, under which landowners were paid to pump groundwater either in lieu of surface-water deliveries or to supply additional water to canals. The reported supplemental pumping for the water bank in 2003 represented a $41 \%$ increase over the estimated pumping during 2000 in the upper Klamath Basin. Most of this increased pumping took place in the Lower Klamath Lake subbasin and lower Lost River drainage, which includes the Tule Lake subbasin. In 2004, supplemental pumping increased approximately $300 \%$ over the volume pumped in 2000 , and the 2006 pumpage represented a 56\% increase (Gannett et al., 2007 p. 41).

Supplemental groundwater pumping continued through 2007. There was no stated Project-sponsored supplemental groundwater pumping in 2008 and 2009, but drought conditions in 2010 resulted in supplemental pumping of over 12,300 hectare-meters (100,000 acre-feet). 


\section{Changes in Discharge to Drains}

TID keeps monthly records of total flows for a large number of diversions, pump stations, and canals on the Project. Of particular importance to the analysis of the change in drain flows is Pumping Plant D (Plant D), which pumps water from the Tule Lake sumps through Sheepy Ridge to the Lower Klamath Lake subbasin. Because the sumps are the ultimate collector of drain water from the Project, flow through Plant D is a reasonable proxy for net discharge to drains over much of the Tule Lake subbasin.

Records of water volumes moved through Plant D indicate that there has been a reduction in flow to agricultural drains on the Project since 2001 (Figure 5). Flow over the past decade has decreased by approximately 7,500 hectare-meters (approximately 60,000 acre-feet) in a fairly linear manner (from roughly 10,000 hectare-meters (approximately 81,000 acre-feet) in 2000 to 2500 hectare-meters (approximately 20,000 acre-feet) in 2011). The timing and volumes of the observed decline in drain flow from the Project are consistent with impacts from increased groundwater pumping. 


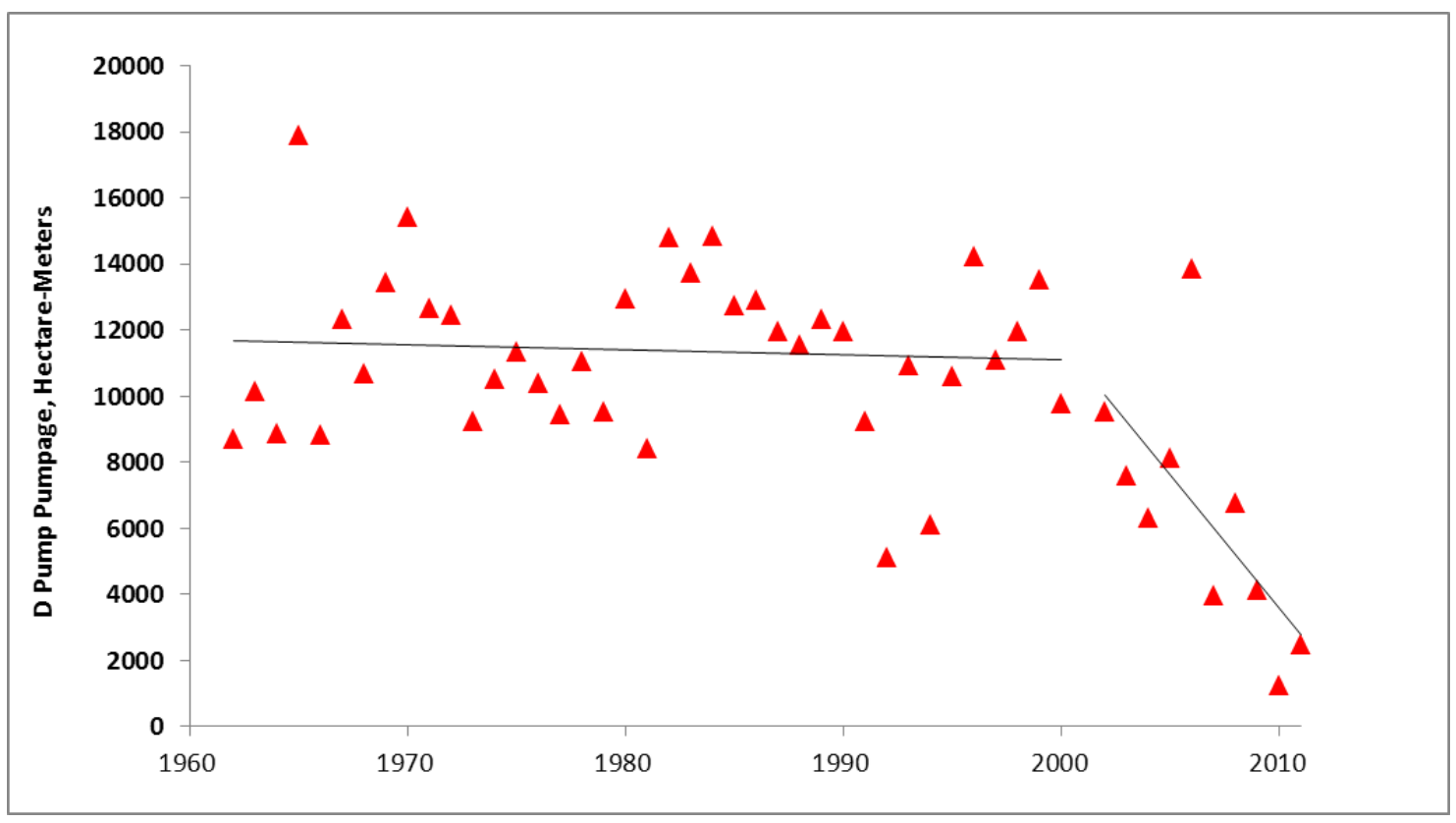

Figure 5. D Pump pumpage in hectare-meters, from 1961 to 2011. Data point for 2001 has been removed because it was an anomalous year and does not represent average conditions.

\section{Sources of Water to Wells}

It is well established that surface water features such as wetlands, streams, springs, and drains can be potential sources of water to wells (Barlow and Leake, 2012). As a well is pumped, most of the water initially supplied to the well is from aquifer storage. If pumping continues, a cone of depression forms in the aquifer around the well which over time can intercept groundwater that would otherwise flow to surface water features (Theis, 1940). Captured water from these surface features consists of either a reduction in the natural discharge of groundwater from the aquifer or an increase in the natural or artificial recharge rate to the aquifer (Theis, 1940; Barlow and Leake, 2012). The manifestation of these effects to surface water features depends on pumping rate, duration, and the geometry and hydraulic characteristics of the aquifer being pumped. 
Changes in Hydraulic Head and Flow

Groundwater pumping in the Klamath Project area over the past decade has removed groundwater from storage, resulting in changes in hydraulic head that are reflected in water-level declines in wells. Between 2001 and 2004, total declines of over 3 meters (10 feet) were documented in the volcanic aquifer over large areas of the Klamath Project, with declines exceeding 5 meters (15 feet) over much of the northern portion of the Tule Lake subbasin (Gannett et al., 2007). Recent analysis by the Oregon Water Resources Department document declines since 2001 of 3 to 6 meters (10 to 20 feet) over much of the area of the Klamath Valley and northern part of the Tule Lake subbasin, with declines of 6 to 9 meters (20 to 30 feet) in some areas (Gall, 2011). Hydrographs of water level trends in monitoring wells show that declines occur in all geologic units at all depths, but are largest in the volcanic aquifer underlying the area (Figure 6). 


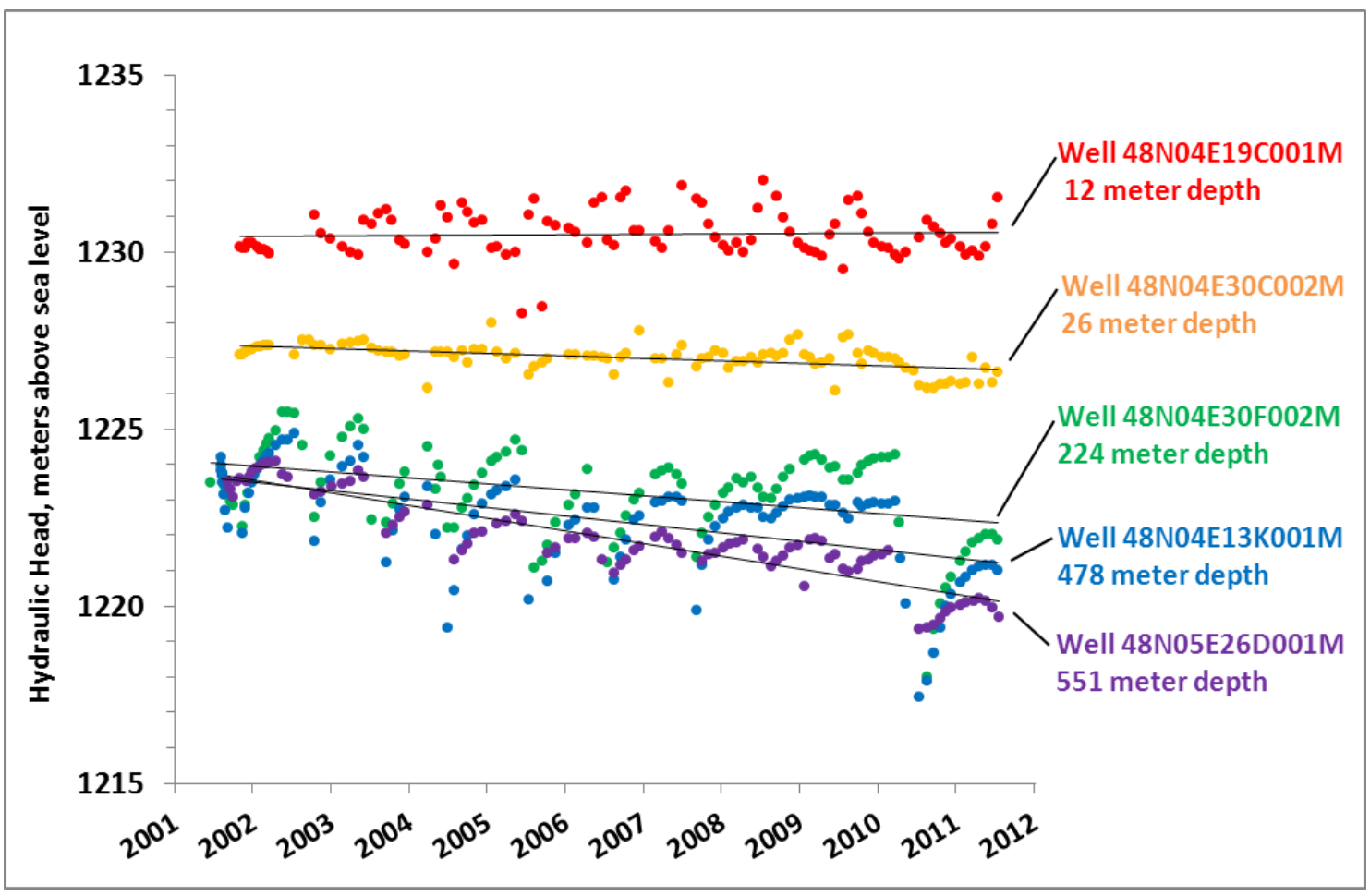

Figure 6. Hydrographs of five wells within the same geographic location in the Tule Lake subbasin. Hydraulic heads have decreased more rapidly in deeper zones over the period of record, which has increased the vertical hydraulic gradient.

Groundwater moves from regions of high hydraulic head to low hydraulic head according to Darcy's law (Freeze and Cherry, 1979). In the hydrogeologic regime of the Tule Lake subbasin, hydraulic heads have historically been lower in the deep basalt aquifer than in the shallow sedimentary aquifer, so there has historically been a component of downward vertical flow. As can be seen in Figure 6, hydraulic heads at depth dropped faster than heads in shallower parts of the system over the past decade. In other words, the downward vertical head gradient (the change in head over a depth interval) has increased, increasing the downward component of groundwater flow. Thus, it may be expected that the proportion of shallow groundwater flowing vertically to the deep aquifer rather than laterally discharging to drains has increased. Analysis of 
hydrologic data from the Klamath Project presented later in this thesis indicates that discharge to agricultural drains has diminished in concert with increases in groundwater pumping.

\section{USGS Regional Model}

The USGS developed a regional groundwater model for the upper Klamath Basin to simulate regional groundwater flow that can be used to help understand the resource and test management scenarios within the basin (Gannett et al., 2012). Simulations of pumping in the Tule Lake subbasin indicate that a substantial portion of the water pumped from the deep aquifer is ultimately captured from diminished discharge to drains. Simulation results are entirely consistent with everything presently known about the groundwater system, and with independent data on changes in water levels and drain discharge (as indicated by records from Plant D).

Due to the coarseness of the model grid, however, this USGS regional-scale flow model cannot simulate the details of the observed changes in vertical head gradients. For example, the model cannot accurately simulate the vertical hydraulic head gradients observed within the basin-filling sediment. The bulk of the sediment is represented as a single layer in the model. Because of this, much of the information from dozens of observation wells in the Tule Lake subbasin is not fully utilized for model calibration or used to evaluate model accuracy. This limits the model's utility in providing insights to the connection between deep and shallow parts of the groundwater system, and quantifying the relative contribution of all of the potential causes of decreased drain flow. 


\section{Study Objectives}

There is evidence to suggest that agricultural drains are affected by increased groundwater pumping. One line of evidence that suggests this is that the regional groundwater model shows that water pumped from the deep aquifer is ultimately captured from diminished discharge to drains. However, as discussed previously, the coarseness of the regional model's vertical discretization and inability to simulate observed vertical gradients makes these results uncertain. Another line of evidence that drains are impacted by increased groundwater pumping is that volumes of water pumped from Pumping Plant D have decreased sharply since groundwater pumping increased in 2001. It should be noted, though, that the D Plant integrates drain flow for the entire Tule Lake subbasin. This means that factors other than the decrease in the groundwater component of drains could be at play in the decrease seen at the D Plant. For example, decreased surface water inputs to drains due to increased irrigation efficiency could manifest as decreased volume pumped through the D Plant. Additionally, the management of the D Plant has changed since the mid-2000's when power prices rose dramatically. It has become prohibitively expensive to run the D Plant, so the decreases in volumes pumped may reflect a decision to use the water in the Tule Lake sumps elsewhere within the Tule Lake subbasin rather than pump it via the D Plant to Lower Klamath National Wildlife Refuge. 
The goal of this thesis is to understand the magnitude of changes to drain flow in the Tule Lake subbasin and the degree to which increased groundwater pumping is responsible for these changes. In order to understand the impact to drains due to increased groundwater pumping, this goal has been divided into two objectives:

1. Construct a quantitative hydrologic budget of the drains in order to understand how the groundwater component of drain flow has changed over time and space as groundwater pumping has increased.

2. Develop a fine-grid groundwater model of the Tule Lake subbasin to provide insight into the connection between groundwater and surface water in the subbasin. 
Methods

Objective 1: Hydrologic Budget for Drains

In order to fulfill the first sub-element of the project objective, flow data from KID and TID were analyzed. KID and TID manage the irrigation infrastructure, including drains, in the Oregon and California portions of the Tule Lake subbasin, respectively. The focus of this analysis was the change in volume pumped from drains over time as a proxy for flow into the drain system. The objective was to understand how the groundwater component of flow in agricultural drains has changed since groundwater pumping increased. TID infrastructure includes 24 pumps that lift water from agricultural drains back into the water delivery system (canals and laterals) for reuse, or into the Tule Lake sumps for storage and removal to Lower Klamath National Wildlife Refuge (via Pump D). TID maintains monthly records of the volumes pumped from these drain pumps, which are located throughout the TID system (Figure 7). In order to analyze these data, monthly timeseries for years 1997-2012 were summed to create yearly volumes for pumps that remove water from specific areas. 


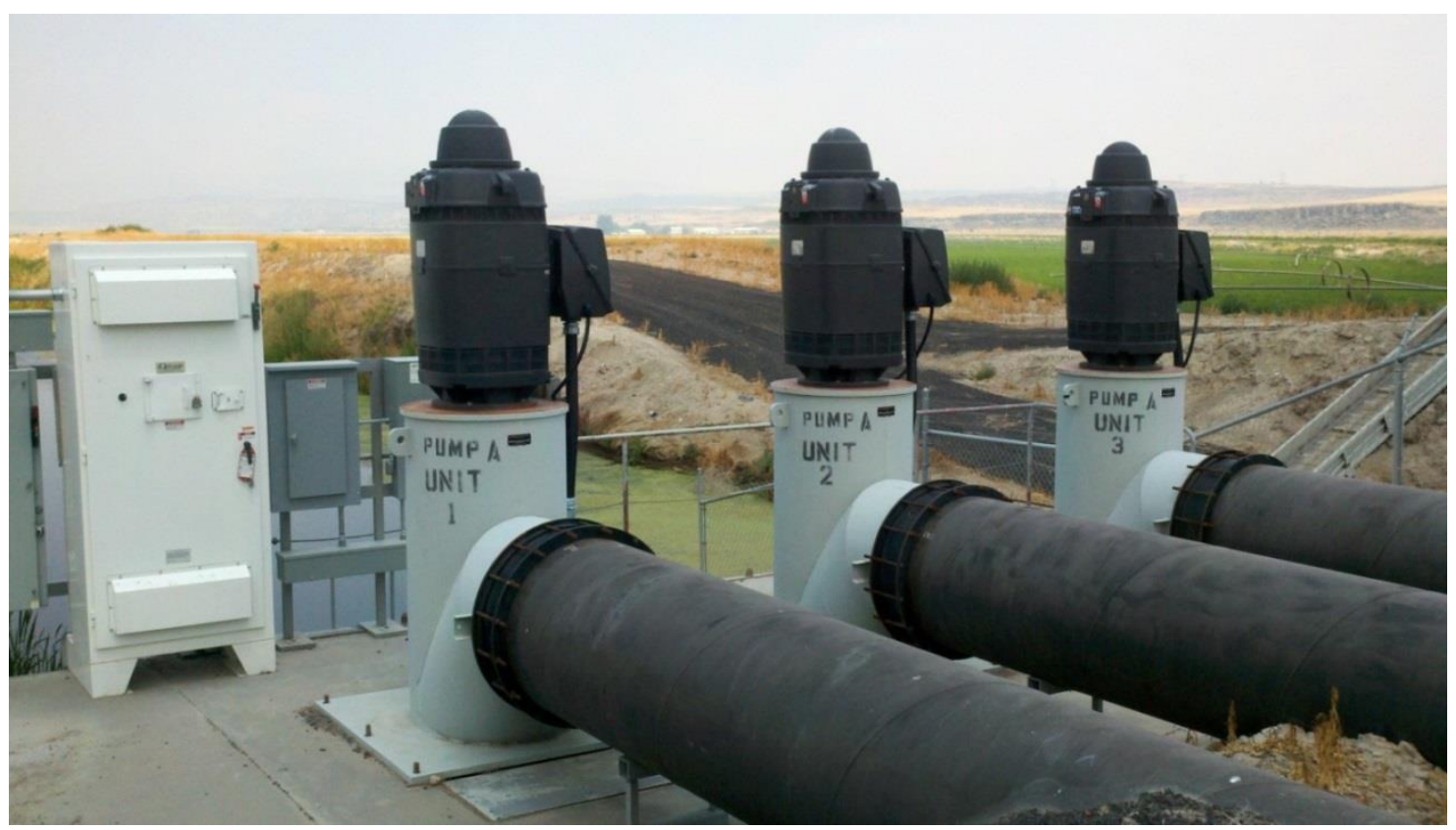

Figure 7. Example of a drain pump in the TID system. Shown here is Pump A.

When evaluating drain pump data to estimate net groundwater discharge, care must be taken to avoid "double counting." Every drain pump's yearly volume could be summed to give the total volume pumped each year for the entire irrigation district.

However, this would introduce a potential issue with possible double counting of water. Drain water to be reused is pumped into a canal or lateral where it is then diverted and applied to crops. Of this reused water, an unknown proportion is lost to evapotranspiration and an unknown proportion is returned to the shallow groundwater through deep percolation where it may become drain flow again. If all of the drain pumps are summed for the entire irrigation district, the water that is recycled and enters the drain system again is being counted more than once. To avoid such double counting of drain water, the irrigation districts were split into three distinct subareas for which terminal sets of pumps could be identified that discharge water outside the subarea. Yearly net 
volumes were calculated for these "terminal" drain pumps and then summed to provide an estimate of total pumped volume per year for the entire irrigation district. The subareas delineated for this analysis are described below.

\section{Subareas}

Subareas were selected based on terminal pumps that integrate flow for the entirety of each area selected. Each pump chosen had the characteristic that it was at the end of the drain system for that particular subarea and pumped into a part of the TID infrastructure that does not recycle water back into the same subarea. This way the double counting of water was avoided or minimized. The three subareas are described briefly in the following paragraphs.

\section{North TID/KID}

North TID/KID is the largest of the subareas (Figure 8). It extends from the north part of the Tule Lake Subbasin south to the edges of the Copic Bay subarea and east to the Lease Lands subarea. It covers the northern extent of the basin-fill sediment and is bound at its northern edge by the Tertiary sediments and volcanics that comprise the deep volcanic aquifer, by a small portion of Quaternary basaltic and andesitic lavas at its southern extent, and by fault blocks typical of the Basin and Range to the east and west. Pumping wells occur in this subarea primarily to the north and east. The drain pumping plants that integrate this area are 3, 4, 5, 6, 12, 27 and A. These plants pump drain water into major canals that supply water to other subareas; this water is not reused in the North TID/KID subarea. 


\section{Copic Bay}

Copic Bay is located in the southeast corner of the study area (Figure 8). It is bisected by a landform known locally as "The Peninsula" which is composed of Quaternary hydrovolcanic deposits. Copic Bay is bounded to the east by a fault block and to the south by Quaternary volcanics from Medicine Lake Volcano. Groundwater pumping takes place throughout this subarea. Pump B is located at the end of the Copic Bay system and integrates most of the drain flow. Pump B discharges into Sump 1-B, and the water is not recycled within the Copic Bay subarea.

\section{Lease Lands}

There are 8903 hectares $(22,000$ acres $)$ of federal land within the Tule Lake NWR that are leased to farmers. These lands are referred to as the Lease Lands (Figure 8). The Lease Lands are located directly south and east of Sump 1-A and north of Sump 1-B, and contain the lowest elevations in the subbasin. The pumps that integrate this region are Pumps 9, 10, 10A, 11, and C, which pump directly into sumps 1-A and 1-B. The water pumped from the drains into the sumps is not reused within the subarea, reducing the chance that drain water will be double accounted. Unlike the North TID/KID and Copic Bay subareas, little to no groundwater pumping takes place in the Lease Lands. 


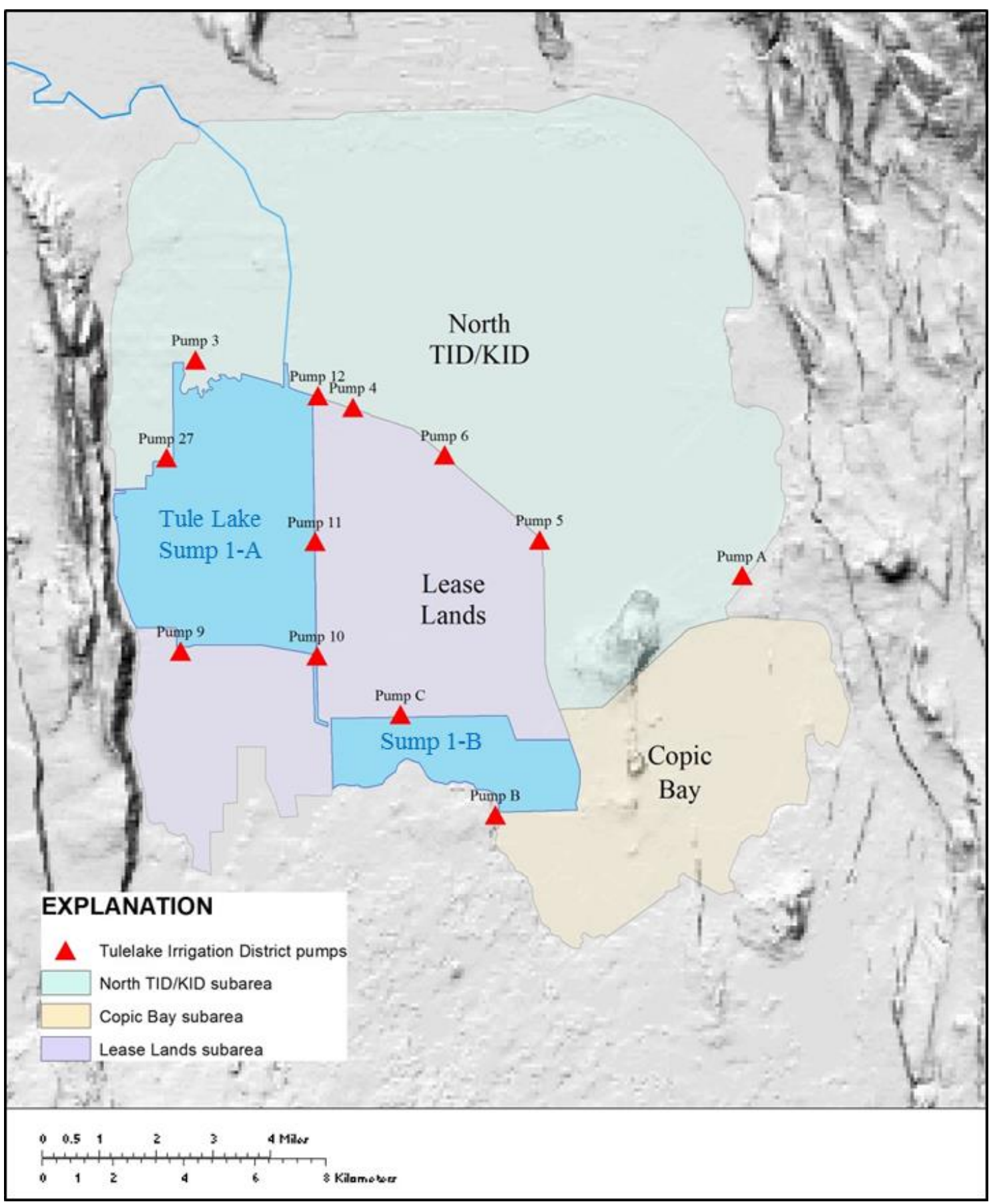

Figure 8. Subareas and drain pumps used in analysis of TID drain flow. 
Operational Spills

In order to understand the changes that have taken place in drain flow due to changes in the groundwater system, it is necessary to subtract out the component of the drain flow that is from surface water. One quantifiable source of surface water to drains is operational spill from KID. Operational spill, as mentioned previously, is the excess irrigation water at the end of the KID's canal system that is spilled to TID's drains. Subtraction of the operational spill component of drain flow is necessary because changes in surface water deliveries to drains could mask changes occurring in the groundwater component of flow. KID keeps monthly records of volumes spilled from the D Canal system, which is at the tail end of the irrigation district and which spills to TID's drains. The monthly KID operational spill data were summed to create yearly spill volumes. These volumes were then subtracted from the total yearly TID drain pump data. It should be noted that the operational spill volumes recorded by the KID are not precise and include visual estimates of flow. However, they are the best information available to understand the approximate magnitude of spills to TID drains. Another quantifiable source of additional water to drains is backspill from canals to keep water levels in drains high enough at certain drain pumps for them to work effectively. This occurs at one drain pump used in this analysis: Pump A. TID maintains records for the volumes spilled to Pump A to keep it operational, and following similar protocol as with the other data in this analysis, the monthly volumes were summed into yearly figures and subtracted from the total drain pumpage. Operational spill from KID and TID backspill to Pump A are two sources of surface water that can be reasonably estimated. There are other potential 
sources of surface water to drains that cannot be as easily quantified, such as direct runoff from fields (over-land flow).

\section{Objective 2: Groundwater Model}

A fine-grid groundwater model was constructed, synthesizing hydrologic and geologic data for the subbasin. Like the regional model, the Tule Lake model was built using the U.S. Geological Survey MODFLOW 2000 modeling code. Subbasin geometry and starting values for certain parameters were taken from the regional model.

Calibration of the model was done using 38 time series observations from wells in the study area. The model was calibrated using the trial-and-error method as well as with inverse methods in which hydrogeologic parameters were estimated using observed head values. The calibration was also constrained by observed drain flows and independent estimates of recharge.

\section{Discretization}

Numerical modeling requires that the model domain be divided into discrete regions or cells; the numerical approximation of the groundwater flow equation is then solved for each of these cells given various inputs, which will be described further in this section. As discussed previously, the present USGS regional-scale flow model (Gannett et al., 2012) cannot simulate the details of the observed changes in vertical head gradients due to the coarseness of the model grid. To address the limitations of the regional model, the Tule Lake subbasin was discretized at a finer scale in the horizontal and vertical dimensions so that data from pumping and observation wells at all depths could be utilized to understand effects due to increased groundwater pumping. Finer horizontal 
discretization also allows for finer resolution in features such as drains and in hydrogeologic zonation.

Cells in the Tule Lake model have a lateral dimension of 381 meters by 381 meters (exactly $1 / 4$ the area of cells in the regional model), which captures the resolution of important features such as drains while limiting the number of model cells for efficiency of model computation. The model domain is 84 rows north to south and 67 columns east to west (Figure 9) with a total of 5628 model cells, and in the vertical dimension there are 12 layers of varying thickness (Table 1). Thicknesses range from approximately 8 to 213 meters ( 25 to 700 feet) and are based on the availability of observation well data. Transient models also require that time be discretized into specific increments. MODFLOW requires two types of time increments: stress periods and time steps. A stress period is a time interval over which specified boundary fluxes, such as recharge and pumping, remain constant. Stress periods are divided into time steps, which enable the model user to better evaluate timing of the hydrologic response to changes in stresses and also improve numeric stability. The Tule Lake model has been constructed to simulate quarterly stress periods from water year 2000 through 2010 preceded by a single steady-state stress period. (Water years begin on October 1 and end on September 30. For example, the 2000 water year starts October 1, 1999 and ends September 30, 2000.) The steady state stress period is in place in order to establish initial conditions for the transient simulation. The set of equations in this groundwater flow model were solved using the Preconditioned Conjugate-Gradient (PCG) solver package (Hill, 1990). 


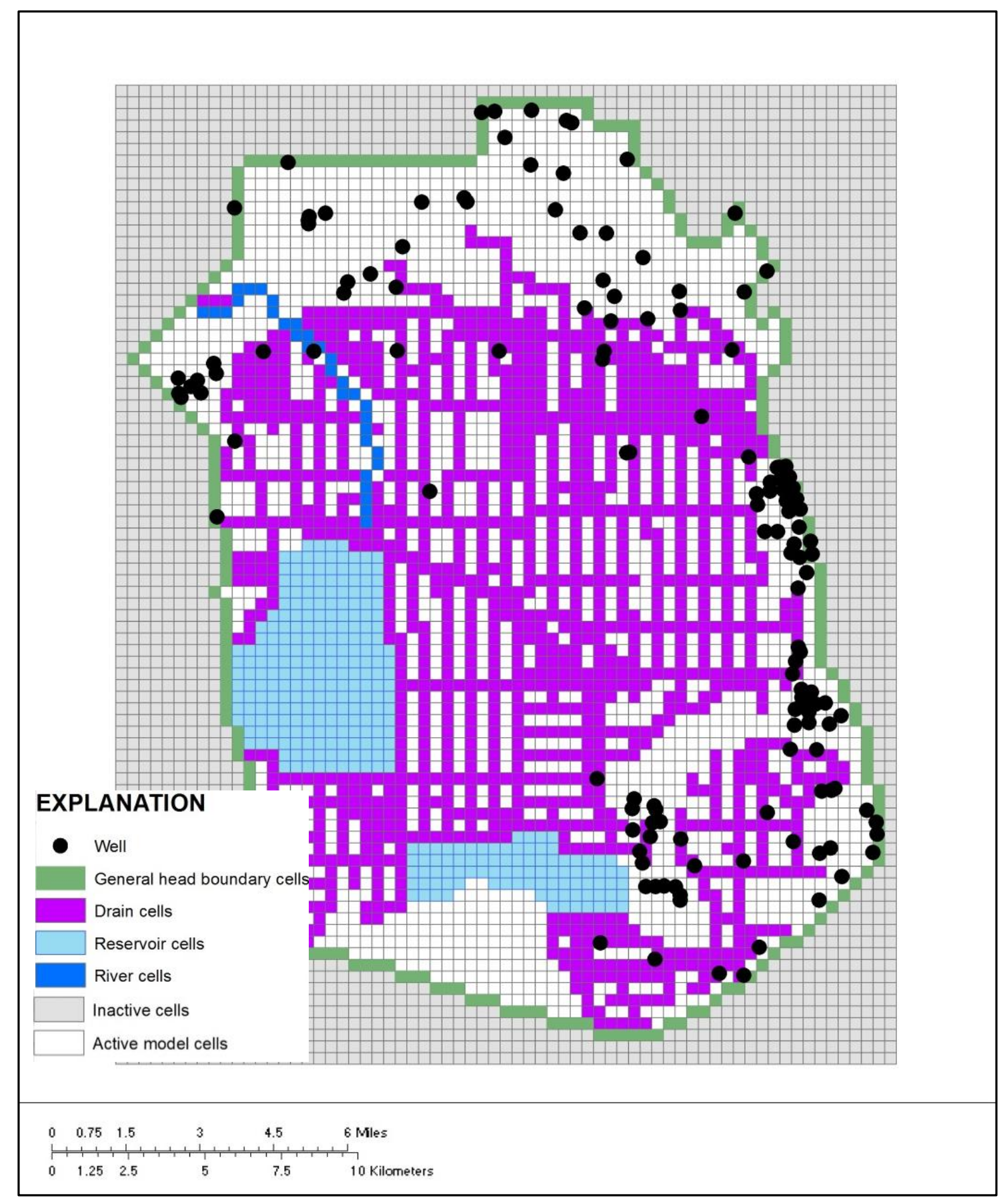

Figure 9. Tule Lake subbasin model boundaries and grid cell types 
Table 1. Layer thicknesses for the Tule Lake subbasin model.

\begin{tabular}{cccc}
\hline Layer & Thickness $(\mathrm{m})$ & Layer & Thickness $(\mathrm{m})$ \\
\hline 1 & 7.6 & 7 & 61.0 \\
2 & 7.6 & 8 & 61.0 \\
3 & 15.2 & 9 & 91.4 \\
4 & 15.2 & 10 & 121.9 \\
5 & 15.2 & 11 & 152.4 \\
6 & 30.5 & 12 & 213.4 \\
\hline
\end{tabular}

Geologic Zonation

The geologic zonation of the Tule Lake subbasin model is based on the hydrogeology of the upper Klamath Basin presented in Gannett et al. (2007) and is specified in the model using the Layer Property Flow (LPF) package. The nomenclature used for modeled hydrogeologic units in the Klamath regional model has been retained for the work presented here. The youngest geologic units in the Tule Lake subbasin are Quaternary sediments (Qs) and Quaternary volcanics (Qv). Quaternary sediments are fine-grained lacustrine sediments and have low permeability (Gannett et al., 2007). Quaternary sediments are the topmost portion of the basin-fill sediment and are only modeled in layer 1. Quaternary volcanics consist of basaltic and andesitic lavas from Medicine Lake Volcano and are present in the southern portion of the study area. The Quaternary volcanics were determined to be 46 meters thick based on well log descriptions, and as such, do not extend below the 4th layer of the model. The older geologic units are Tertiary sediments of younger basins (Tsy) and Tertiary sediments and volcanics (Tsv). The Tsy unit is composed of fine-grained lacustrine sediment and makes up the remainder of the basin-fill sediment. Underlying the basin-fill sediment and outcropping on the fringes of the subbasin are Tertiary sediments and volcanics (Tsv). 
The Tsv unit is composed of middle to late Tertiary basaltic and andesitic lava flows and vent deposits interspersed with fine-grained continental sedimentary deposits (Gannett et al., 2007) and is the major aquifer for the Tule Lake subbasin. The spatial distribution of these units is shown in Figure 10. 


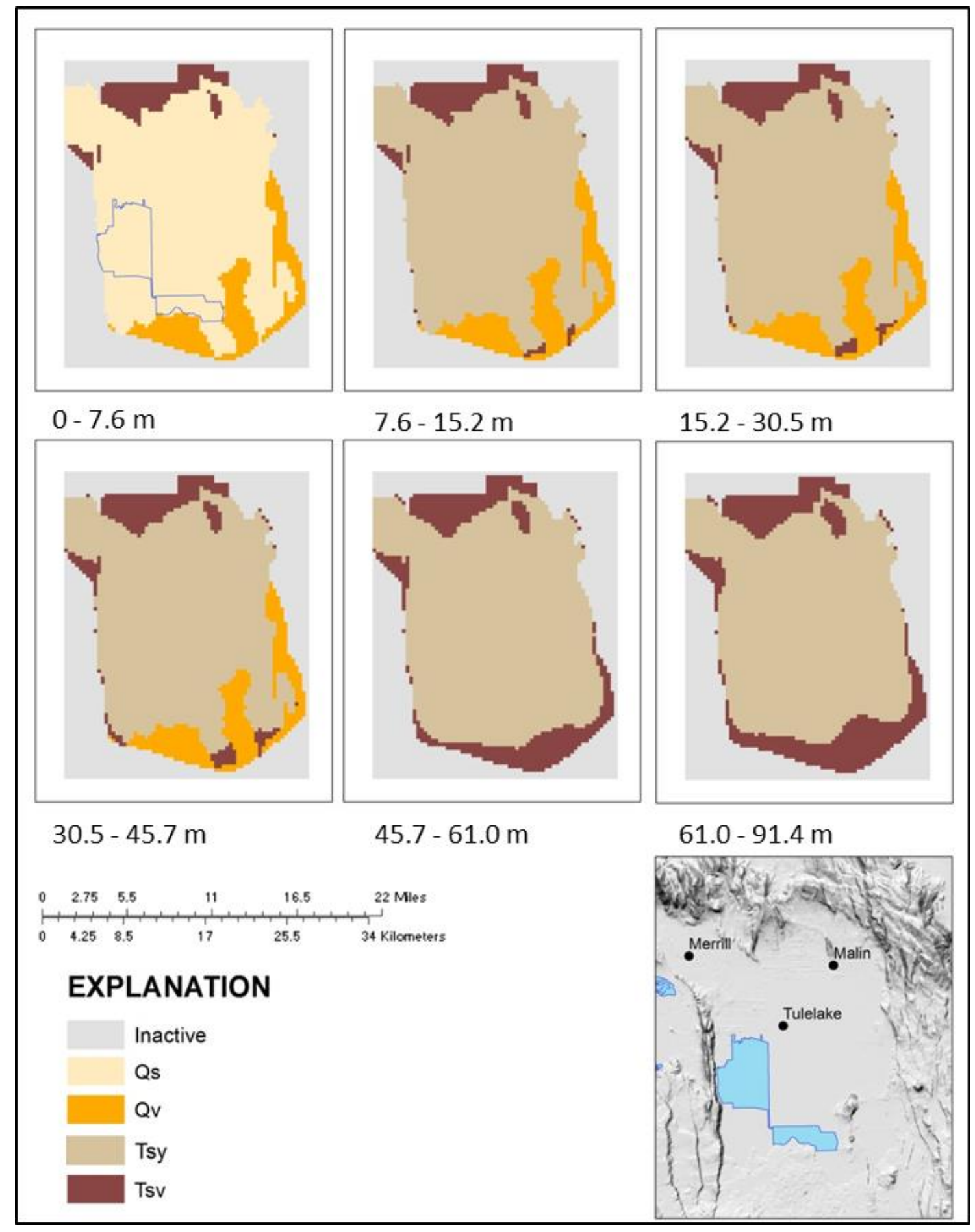




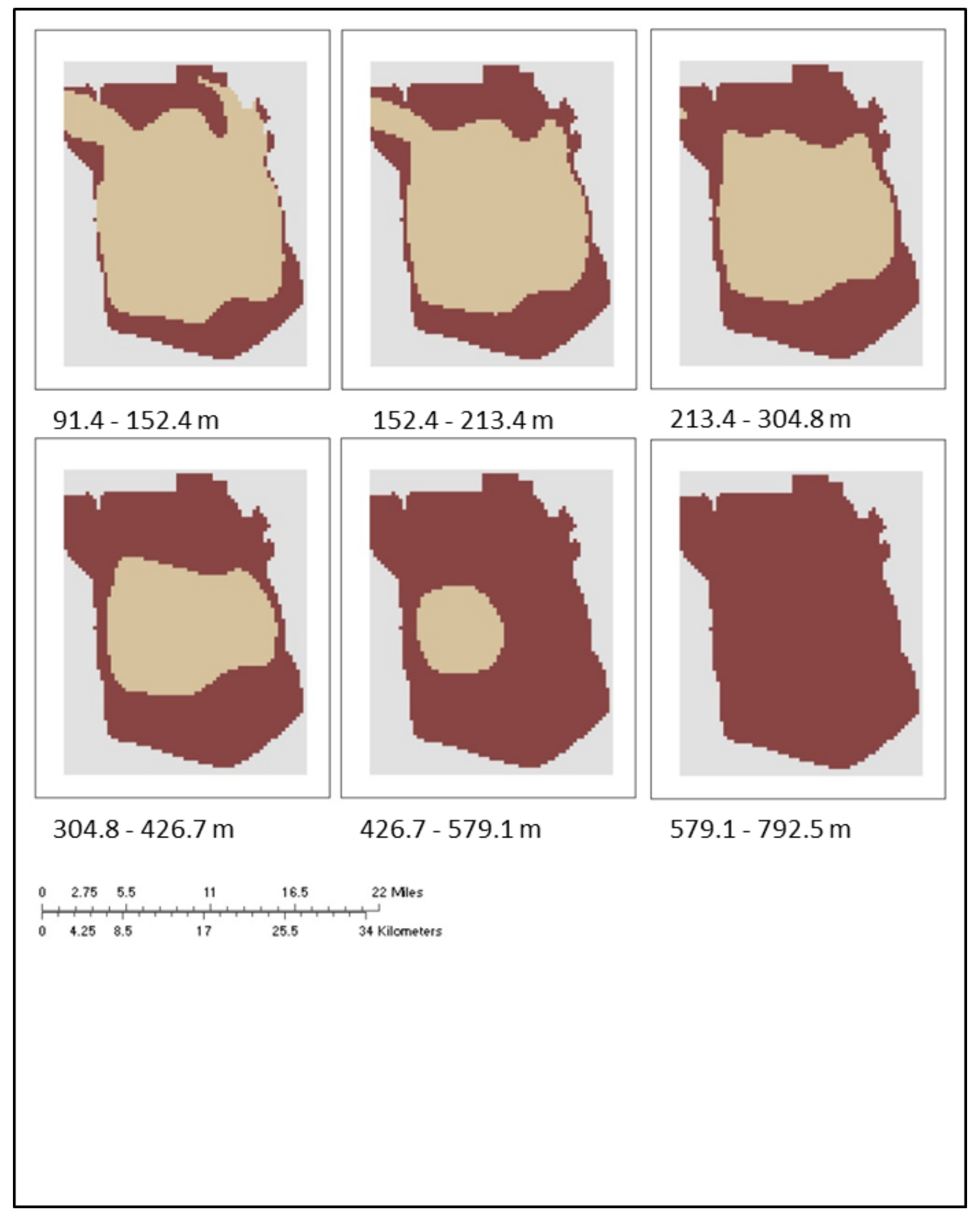

Figure 10. Geologic zonation of the Tule Lake groundwater model. The Tule Lake sumps, shown in the index map in the lower right, are shown in the first layer as a spatial reference. Gray cells are inactive model cells; other colors represent the geology represented in the model. Qs: Quaternary sediments; Qv: Quaternary volcanics; Tsy: Tertiary sediments of younger basins; Tsv: Tertiary sediments and volcanics. The depth interval, in meters, is shown below each layer. 


\section{Boundary Conditions}

Boundary conditions determine heads or flows along the boundaries of a model (Anderson and Woessner, 1992). They describe the way in which water is allowed to move into or out of the groundwater system. Groundwater movement to or from a river is an example of a boundary condition. The boundary conditions present in the Tule Lake model are shown in Figure 9 and described in the following paragraphs.

\section{Specified Flux Boundaries}

Specified flux boundaries are those boundaries for which a specified flow of groundwater into or out of the model occurs. These specified flows can vary in time and space. Specified flux boundaries in this model are recharge and pumping wells.

\section{Recharge}

Recharge is the volume of infiltrated water that crosses the water table and becomes part of the groundwater flow system (Anderson and Woessner, 1992). The primary source of recharge in the Tule Lake subbasin is deep percolation of applied irrigation water and canal leakage. Precipitation is also a source of recharge but comparatively small. The volume of recharge from precipitation was taken from the upper Klamath Basin regional model. It was calculated via the Precipitation-Runoff Modeling System (PRMS), a watershed-based surface water model. Recharge from deep percolation and canal leakage was also taken from the regional model. Recharge from deep percolation and canal leakage was estimated using a water balance calculated for the Klamath Project by the Irrigation Training and Research Center (ITRC) (Burt and Freeman, 2003). A value of $0.3 \mathrm{~m} / \mathrm{yr}$ (1 ft/yr) was applied to the Tule Lake subbasin, 
which is entirely within the Project. For details regarding calculation of recharge volumes for the regional model, refer to Gannett et al. (2012). In the ITRC recharge estimation, groundwater recharge on the Project was calculated from the residual of hydrologic inputs minus outputs. The hydrologic outputs include evapotranspiration (ET). Since ET is already accounted for in the recharge calculation, it is not explicitly modeled using the EVT package.

Given that irrigation is a predominant form of recharge in the Tule Lake subbasin, factors that affect irrigation will affect the volume of recharge. There were refinements to recharge in the Tule Lake subbasin model based on two factors relating to irrigation: the low density of canals in the northern portion of the study area and curtailed Project diversions in the dry years 2001 and 2010. The low density of canals in the northern portion of the study area (Figure 11) mean that less recharge can be expected due to transmission losses and irrigation in that area. Observation wells in that area showed persistently high simulated hydraulic head before recharge was scaled back; recharge was scaled back in that area until simulated hydraulic head in those wells dropped to a level consistent with observed heads. The final value of recharge in the northern portion of the study area was $25 \%$ the original value. 
The other refinement in recharge in the Tule Lake model was related to curtailed irrigation diversions in 2001 and 2010. In all years except 2001 and 2010, the $0.3 \mathrm{~m} / \mathrm{yr}$ recharge rate was used. Since the Project received considerably less surface water for irrigation during the dry years of 2001 and 2010, it can be expected that recharge from deep percolation of applied irrigation water and canal leakage will be reduced in the same proportion as the reduced diversions. To account for decreased diversions, recharge was scaled back to $32 \%$ of the original recharge volume in 2001 and to $55 \%$ of the original recharge volume in 2010 to match the scaling-back of irrigation diversions those years. 


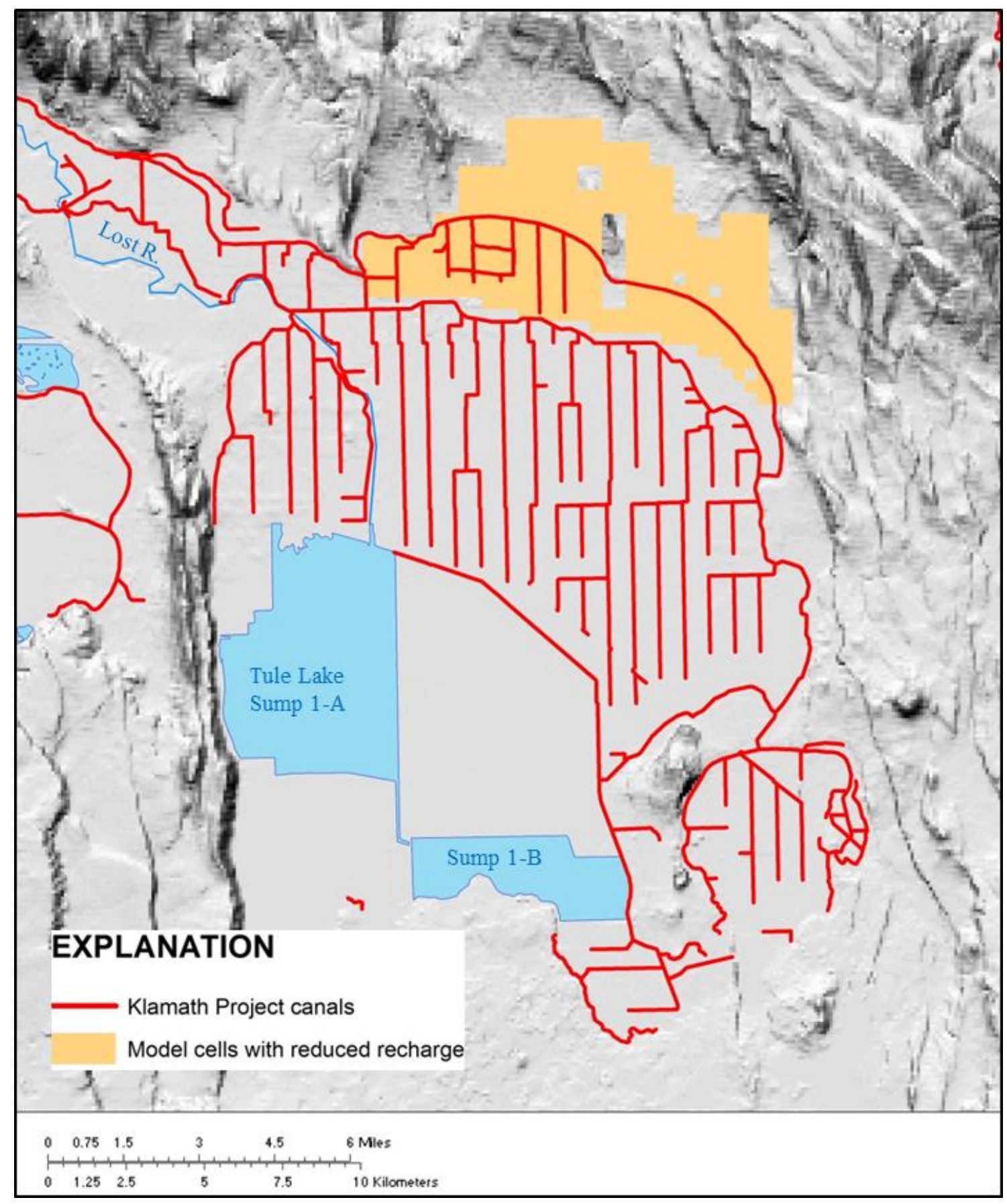

Figure 11. Cells with reduced recharge due to lower density of canals. Cells highlighted have a recharge value of $25 \%$ the original value. 


\section{Pumping Wells}

Pumping wells are also considered specified-flux boundaries. Within the Tule Lake subbasin there are two types of groundwater pumping: background and supplemental. Background pumping comprises pumping that goes on year-round by water users whose primary source of water is groundwater. Supplemental pumping is pumping that occurs when surface water is not available. Water bank pumping, in which water users were paid to pump water in lieu of surface water deliveries, is an example of supplemental pumping.

Background pumping rates used in the Tule Lake subbasin model are the same used in the regional model; estimates are based on land use surveys, analysis of satellite imagery, and water rights information. Within the Tule Lake subbasin, this averages 983 hectare-meters per year. Supplemental pumping volumes are based on information from Bureau of Reclamation, Oregon Water Resources Department (OWRD), and the Klamath Water and Power Authority (KWAPA). Supplemental pumping in the model averages 2896 hectare-meters per year. The pumping data were provided in differing formats depending on the year and the agency. For years 2001-2004, the pumping data were given as an annual total for individual wells or groups of wells. For 2005 through 2007, the data were given as the aggregate total of pumping for all supplemental wells. The quarterly pumping volume used in the model for each well in 2005-2007 was obtained by apportioning pumping volumes based on the relative apportionment for wells in 2004 (2004 data were provided for single wells). There was no paid water bank pumping in 2008 and 2009, and in 2010 data were provided well-by-well by OWRD and KWAPA. 
Some input values for supplemental pumping were modified from reported values to adjust for possible under- or over-estimation of pumping rates. For example, there was no stated water bank pumping in 2008 and 2009. However, hydrograph data of wells during those years show some impact due to pumping. Additionally, pumping rates in 2001-2004 were adjusted to reflect new information on actual pumping capacities of wells and to better match observed relative drawdowns in hydrograph data.

The average rate of pumping is defined for each stress period in cells that contain a pumping well. Pumping is simulated in MODFLOW-2000 using the WEL package.

\section{Head-Dependent Flux Boundaries}

Streams, lakes, and drains are examples of head-dependent flux boundaries. Evapotranspiration is generally regarded as a head-dependent flux boundary. However, ET was accounted for outside of the model and so is reflected as net recharge due to deep percolation of applied irrigation water. The rate of groundwater flow to or from these features depends on the difference between the head in the cell and the head of the feature (such as the stream, lake, or drain). Head-dependent flux boundaries are discussed in the following sections.

Rivers

The Lost River is the only river in the study area. The spatial extent of the river within the model domain was determined using digital geographic (GIS) data, and river width and stage were determined using 1:24,000 USGS topographic maps. The Lost River is modeled using MODFLOW's RIV package. Water from a RIV boundary can 
move to or from the groundwater system depending on the head difference between the river and the cell in which it is modeled. The rate of flow is proportional to the riverbed conductance. The initial riverbed conductance was calculated based on estimates of aquifer properties from the regional model and then adjusted during calibration.

Lakes

The Tule Lake sumps are modeled as reservoirs in the model, since they are artificially controlled. As such, they are modeled using MODFLOW's RES package. The spatial extent of each sump was determined using a USGS 1:24,000 topographic map. Stage measurements of the Tule Lake sumps were not available during the simulation period, so the water level in each sump was fixed at a long-term average value of 1229 meters (4033 ft.) (Gannett et al., 2007). Water moves to or from the sumps in proportion to the head difference between the sumps and the cells in which they are modeled and the conductance of the reservoir bottom. The initial RES conductance was calculated based on estimates of aquifer properties from the regional model and then adjusted during calibration.

Drains

Agricultural drains are modeled using MODFLOW's DRN package. The spatial distribution of drains in the study area was delineated using GIS data provided by Bureau of Reclamation. The depth of the drains was set to 3 meters (10 feet) based on field observations and the USGS model calibration, and the drain width was set to a constant 3 meters. Drain stage was set at 3 meters below land elevation, with a minimum stage of 1227 meters (4025 feet). Like other head-dependent flux boundaries discussed so far, the 
flux of water to the drain is dependent on the head difference between the drain and the cell in which it is modeled and the conductance of the drain bottom. Unlike other headdependent flux boundaries, flux in drain cells is unidirectional, that is, flow can only occur from the groundwater system to the drain (as opposed to a RIV cell, for example, in which flow can move from the groundwater system to the river, or from the river to the groundwater system). This accurately models what occurs in reality, because drains are designed to provide an outlet for shallow groundwater to be carried away, and do not function as a source of groundwater to the aquifer as a river can. The initial drain conductance was calculated based on estimates of aquifer properties from the regional model and then adjusted during calibration.

\section{Interbasin Groundwater Flow}

The final type of head-dependent flux boundary present in the model is that which simulates interbasin groundwater flow. There is known flow from the groundwater system of the Tule Lake subbasin to the south to the Pit River basin (Gannett et al., 2007). Maps of hydraulic head show a southward gradient, suggesting groundwater flow in that direction. Anecdotal evidence also leads to this conclusion; prior to the subbasin being drained in the early 1900 's, eyewitness reports indicated that water flowed into the permeable basalts to the south. The fact that Tule Lake was a freshwater lake and not saline also indicates that the lake "in the past had an outlet" (LaRue, 1922). The degree to which interbasin groundwater flow occurs into or out of the Tule Lake subbasin at other points is not well known. What is known, however, is that the Tertiary volcanic aquifer and basin-filling sediment within the subbasin are permeable, and that these may extend 
beneath the fault-block ridges that separate the Tule Lake subbasin from the basins to the north, east, and west, allowing groundwater to flow between subbasins. General head boundary cells, therefore, are located all around the edge of the model domain. General head boundary (GHB) cells allow the transmission of groundwater to or from the subbasin.

General head boundaries behave in a similar manner as the river or reservoir boundaries. Take the river boundary, for example. The river can be thought of as an outside source (or sink) of water to the model. The hydraulic head of the outside source (the river) is specified, and the difference between the head in the source and the head in the cell dictate whether water will flow from the source to the groundwater system or vice versa. Similarly, an outside source of water is defined for each general head boundary cell. The hydraulic head in the outside source is specified, and the inflow or outflow of water to the model is dependent on the head difference between the outside source of water and the head in the general head boundary cell. Like all other head dependent boundaries, the flux of water is also proportional to a GHB conductance, which can be thought of as the conductance between the cell and the outside source of water. Hydraulic head values for the outside source are specified; these values are taken from subsurface head contour maps derived from well measurements at the edge of the active model domain. The initial GHB conductance was calculated based on estimates of aquifer properties from the regional model then adjusted during model calibration. 


\section{Model Calibration}

Calibration is a process in which model outputs (simulated values) are compared with measured quantities such as hydraulic head or flow (observed values) to ensure that the model is doing an adequate job of simulating actual conditions. To calibrate a model, the model's structure and input parameter values are adjusted until an acceptable fit between the simulated and observed values is attained. Model fit will be discussed later in this thesis.

Model parameters are inputs such as system geometry and properties, initial and boundary conditions, and stresses that can be changed so that the model output matches related measured values (Hill and Tiedeman, 2007). Parameters in the Tule Lake model include hydraulic conductivity, vertical anisotropy, and specific storage of various geology types represented in the model. For a full list of parameters in this model, refer to Table 3 in the Model Results section.

The measured values that are used for model calibration in the Tule Lake model are hydraulic head values from 38 observation wells located throughout the subbasin (Figure 12). In addition to observation wells, the changes in summed drain pumpage from the three Tule Lake subareas used in the drain flow analysis were used to constrain calibration. Due to the uncertainty in the drain flow observations, they were used in the trial-and-error calibration only, as described below. 
Two methods were employed to calibrate the model. The first is called the forward case, or the trial-and-error method. The trial-and-error method involves adjusting model structure and model parameters by hand to achieve an acceptable match between simulated and observed hydraulic head values. This is an iterative approach in which the structure and/or parameters are hand-adjusted, then the model results analyzed. The second calibration method is called parameter estimation. Parameter estimation is also referred to as the inverse case. Rather than solving for hydraulic head given a set of fixed parameters, the parameter estimation process adjusts the parameters until simulated hydraulic heads match observed heads within a predetermined tolerance. Unlike the trialand-error method, parameter estimation is an automated process that is carried out using MODFLOWP, the parameter estimation program associated with MODFLOW-2000. Both calibration methods were used in conjunction with one another to achieve acceptable model results. 


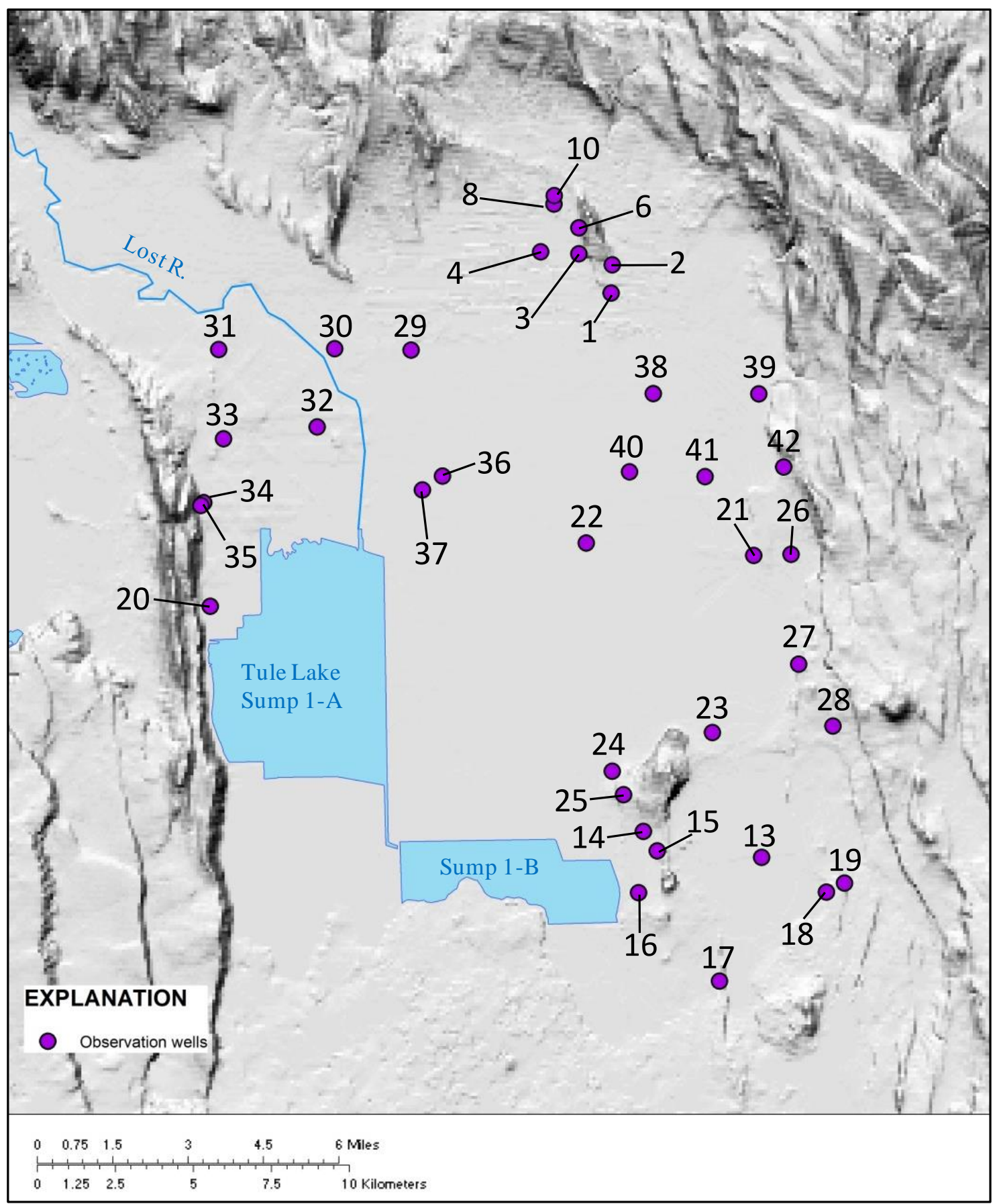

Figure 12. Locations of observation wells for the Tule Lake subbasin model. Wells are numbered with the identification number used in the model. 
MODFLOW 2000 employs a weighted least-squares objective function, S(b), to quantitatively compare observed and simulated values:

$$
S(b)=\sum_{i=1}^{N} \omega_{i}\left[y_{i}-y_{i}^{\prime}(b)\right]^{2}
$$

where,

$\mathrm{b}$ is a vector containing values of each of the parameters being estimated;

$\mathrm{N}$ is the number of observations;

$\mathrm{y}_{\mathrm{i}}$ is the ith observation being matched by the regression;

$y^{\prime}{ }_{i}(b)$ is the simulated value which corresponds to the ith observation (a function of $b$ );

$\omega_{\mathrm{i}}$ is the weight for the ith observation (Hill, 1998).

The solution of the least-squares objective function can be compared between model simulations as a way to test which model fits the data more closely, as is done in the trial-and-error method. The objective function is also used in MODFLOWP, the parameter-estimation routine of MODFLOW 2000. MODFLOWP uses non-linear regression to determine optimal parameter values to minimize the solution of the objective function, also called the sum of squared errors. The purpose of regression is to calculate values of defined parameters that minimize the objective function (Hill, 1998).

The function $\mathrm{S}(\mathrm{b})$ is a weighted least-squares objective function, which means that a weight is applied to the squared residual before the sum of squared errors are 
computed for all observations. A weight is a coefficient applied to a squared residual that reduces its effect on the overall objective function. Weights are applied to observations that have greater uncertainty or that represent stresses not simulated in the model; it also ensures that all residuals have the same units so that they can be compared, if both hydraulic head and flow observations are used in parameter estimation. In the case of the Tule Lake model, only hydraulic head values are used in parameter estimation. The equation for observation weights is

$$
\text { Observation Weight }=\frac{1}{\left(S T A T I S T I C^{2} \times E V H\right)}
$$

where,

Statistic is the scaled standard deviation of the observation, and

EVH is the input variance multiplier for hydraulic head observations (Hill et al., 2000).

In this model, there are well head observations that are weighted so as to remove any influence they have over the parameter estimation regression. These wells either have data that do not span the entire model simulation (as is the case for observation wells 4 , 10, and 25), or their hydraulic head levels reflect a stress not simulated in the model. Remaining observations were weighted equally (Table 2).

The objective function is a useful tool for assessing model fit, but is limited with regards to understanding error and bias in the model. To understand error and bias in the model, the randomness and normality of model residuals must be assessed. An 
explanation of what randomness and normality in model residuals means for the quality of a model and metrics that describe these attributes in the model presented here will be given in the Groundwater Model Results section.

Table 2. Observation wells in the Tule Lake subbasin model.

\begin{tabular}{|c|c|c|c|c|c|}
\hline $\begin{array}{l}\text { Observation } \\
\text { Well No. }\end{array}$ & $\begin{array}{l}\text { Model } \\
\text { Layer }\end{array}$ & Geology & Statistic & EVH & Weight \\
\hline 1 & 7 & Tsv & 0.3 & 1 & 11 \\
\hline 2 & 5 & Tsv & 0.3 & 1 & 11 \\
\hline 3 & 3 & Tsv & 305 & 1 & $1.1 \mathrm{E}-05$ \\
\hline 4 & 7 & Tsy & 305 & 1 & $1.1 \mathrm{E}-05$ \\
\hline 6 & 9 & Tsv & 0.3 & 1 & 11 \\
\hline 8 & 7 & Tsv & 0.3 & 1 & 11 \\
\hline 10 & 5 & Tsv & 305 & 1 & $1.1 \mathrm{E}-05$ \\
\hline 13 & 3 & Tsy & 305 & 1 & $1.1 \mathrm{E}-05$ \\
\hline 14 & 4 & Qv & 0.3 & 1 & 11 \\
\hline 15 & 5 & Tsy & 0.3 & 1 & 11 \\
\hline 16 & 5 & Tsy & 0.3 & 1 & 11 \\
\hline 17 & 5 & Tsv & 0.3 & 1 & 11 \\
\hline 18 & 3 & Qv & 0.3 & 1 & 11 \\
\hline 19 & 5 & Tsv & 0.3 & 1 & 11 \\
\hline 20 & 10 & Tsv & 305 & 1 & $1.1 \mathrm{E}-05$ \\
\hline 21 & 3 & Tsy & 0.3 & 1 & 11 \\
\hline 22 & 3 & Tsy & 0.3 & 1 & 11 \\
\hline 23 & 3 & Tsy & 0.3 & 1 & 11 \\
\hline 24 & 2 & Tsy & 0.3 & 1 & 11 \\
\hline 25 & 3 & Qv & 305 & 1 & $1.1 \mathrm{E}-05$ \\
\hline 26 & 11 & Tsv & 0.3 & 1 & 11 \\
\hline 27 & 6 & Tsy & 305 & 1 & $1.1 \mathrm{E}-05$ \\
\hline 28 & 8 & Tsv & 0.3 & 1 & 11 \\
\hline 29 & 4 & Tsy & 305 & 1 & $1.1 \mathrm{E}-05$ \\
\hline 30 & 4 & Tsy & 0.3 & 1 & 11 \\
\hline 31 & 5 & Tsy & 305 & 1 & $1.1 \mathrm{E}-05$ \\
\hline 32 & 4 & Tsy & 0.3 & 1 & 11 \\
\hline 33 & 4 & Tsy & 0.3 & 1 & 11 \\
\hline 34 & 2 & Tsy & 0.3 & 1 & 11 \\
\hline 35 & 7 & Tsv & 0.3 & 1 & 11 \\
\hline 36 & 6 & Tsy & 0.3 & 1 & 11 \\
\hline 37 & 12 & Tsv & 0.3 & 1 & 11 \\
\hline 38 & 3 & Tsy & 305 & 1 & $1.1 \mathrm{E}-05$ \\
\hline 39 & 4 & Tsy & 305 & 1 & $1.1 \mathrm{E}-05$ \\
\hline 40 & 3 & Tsy & 305 & 1 & $1.1 \mathrm{E}-05$ \\
\hline 41 & 2 & Tsy & 305 & 1 & $1.1 \mathrm{E}-05$ \\
\hline 42 & 8 & Tsv & 0.3 & 1 & 11 \\
\hline
\end{tabular}




\section{Results}

\section{Results of Drain Flow Analysis}

To better understand changes that have taken place in groundwater discharge to drains, an analysis was performed on spill and drain pump data provided by KID and TID. As discussed previously in the Methods section, known surface water contributions to drains were subtracted from the total drain volumes. These include monthly spill volumes from KID and backspill from canals to drains to keep pumps (specifically Pump A) operational. This way, changes in surface water contributions to the drains are removed as much as possible and do not mask changes taking place in the groundwater contribution to drains. Additionally, in order to avoid double counting of water pumped from drains, the TID drain system was split into three distinct subareas and the accounting for each area was limited to pumps that, to the extent possible, integrate flow at terminal ends of the drain system and discharge to other subareas. Pumps that potentially recycle drain water for irrigation within the same subarea were not included to avoid double accounting. The results of this analysis are presented below.

\section{Changes in Drain Flow}

To calculate changes in drain flow since 2000, the 2012 drain pumpage was compared with the 1997-2000 average pumpage. The greatest change in drain pumpage occurred in the North TID/KID subarea, where the 2012 flows were about 2,750 hectaremeters less than the 1997-2000 average after a fairly linear decline (Figure 13). 


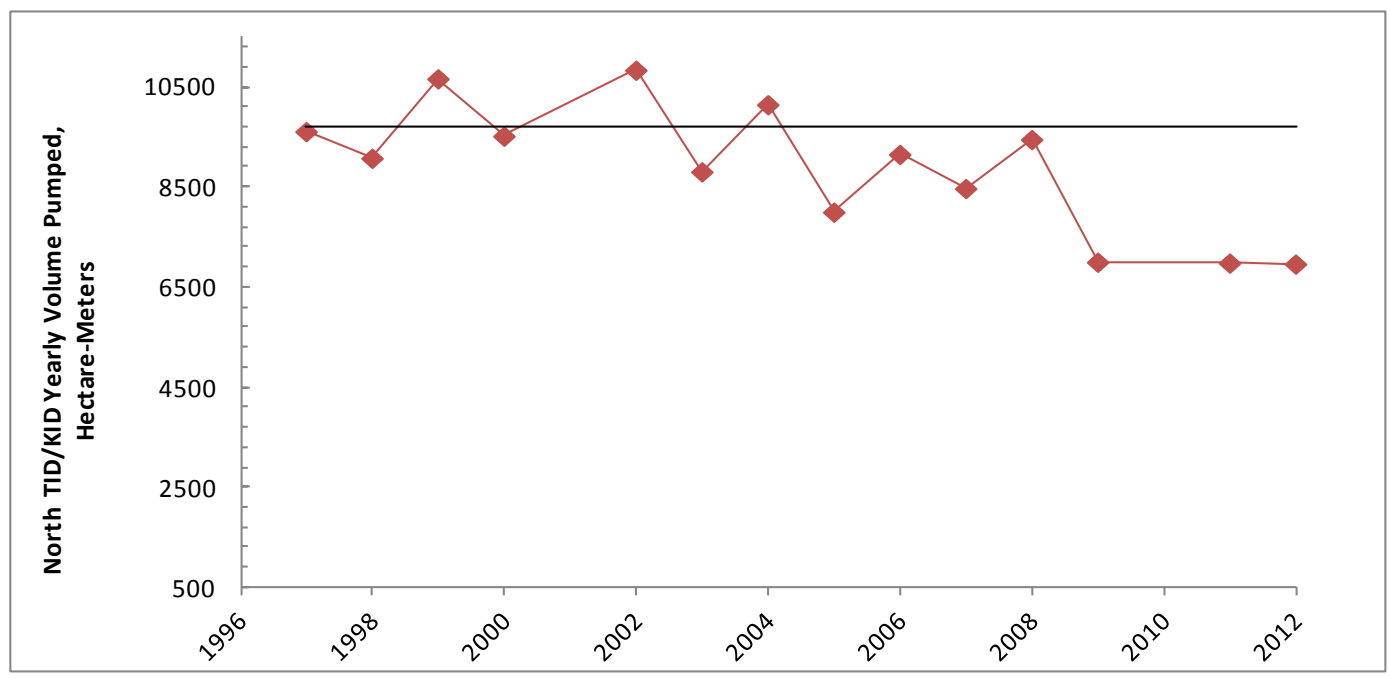

Figure 13. Yearly volume pumped from pumps integrating the North TID/KID subarea, in hectare-meters. Reference line shows the average 1997-2000 pumping. Data for 2001 and 2010 were omitted because of the effects of severely-curtailed surface-water deliveries.

The subarea with the next greatest change in drain pumpage is the Copic Bay subarea, where 2010 drain flows are about 900 hectare-meters less than the 1997-2000 average after a fairly linear decline (Figure 14).

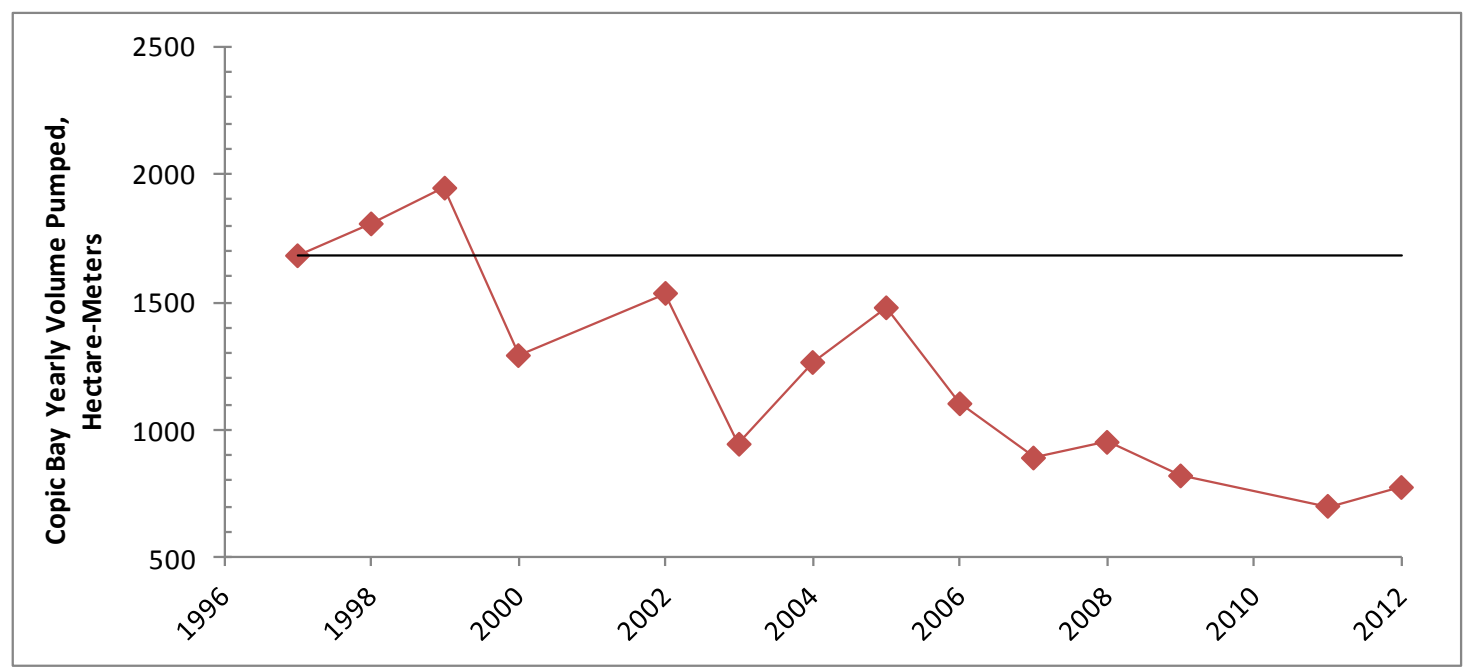

Figure 14. Yearly volume pumped from pumps integrating the Copic Bay subarea, in hectare-meters. Reference line shows average 1997-2000 pumping. Note the scale change between this and plots for the other subareas. Data for 2001 and 2010 were omitted because of the effects of severely-curtailed surfacewater deliveries. 
Lastly, in the Lease Lands subarea of the difference between the 1997-2000 average drain flows and the 2012 values is a loss of approximately 350 hectare-meters (Figure 15). Unlike the North TID/KID and Copic Bay subareas, there is not a clearlydiscernible long-term trend to the drain pumpage in this subarea. On a long-term average basis, the change in Lease Land drain pumpage has been minor. The combined drain flows from the three subareas in 2012 is approximately 4,000 hectare-meters less than the 1997-2000 average.

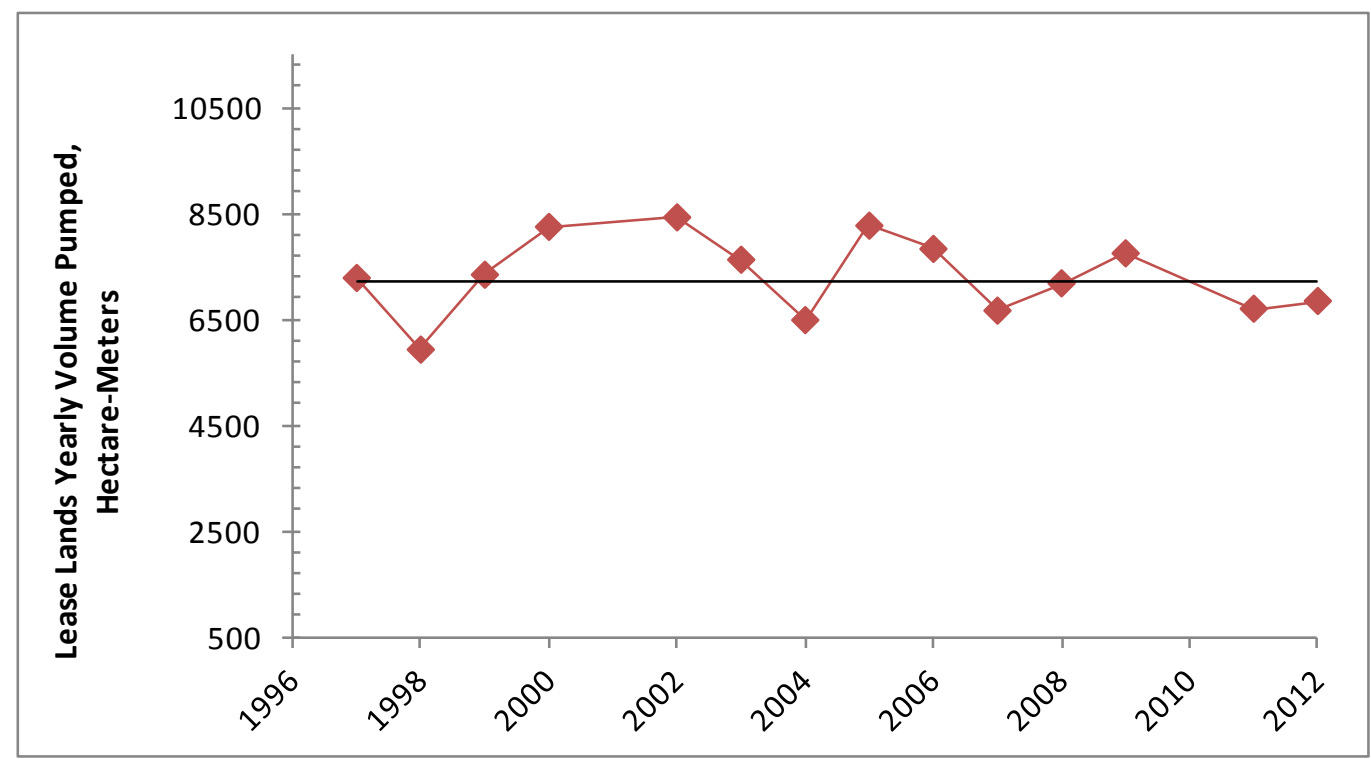

Figure 15. Yearly volume pumped from pumps integrating the Lease Lands subarea, in hectare-meters. Reference line shows average 1997-2000 pumping. Data for 2001 and 2010 were omitted because of the effects of severely-curtailed surface-water deliveries.

Groundwater Model Results

A groundwater model of the Tule Lake subbasin was constructed in order to gain understanding of the sources of water to wells in the subbasin and to test the hypothesis that increased groundwater flow is causing decreased flow to agricultural drains given 
subbasin geometry, boundaries, and hydrogeologic characteristics. In the following section, results of the groundwater model will be presented.

\section{Calibration Results}

The goal of model calibration is to determine the model structure and parameters that together create a model that best simulates reality. Parameter estimation was employed in the construction of this model to determine the optimal parameter values to simulate observed hydraulic heads. The final parameter values are given in Table 3.

Comparing these parameters with the final parameters from the regional model, there are many similarities, and some differences, which will be discussed here. The greatest differences between the parameters in the regional model versus the Tule Lake model are the vertical anisotropy values for the Quaternary sediment (VANI_QS), the hydraulic conductivity and vertical anisotropy of the Tertiary sediments of younger basins (HK_TSY, VANI_TSY), and the specific storage of the upper and lower portions of the Tertiary sediments and volcanics (the volcanic aquifer) (SS_TSVU, SS_TSVL). 


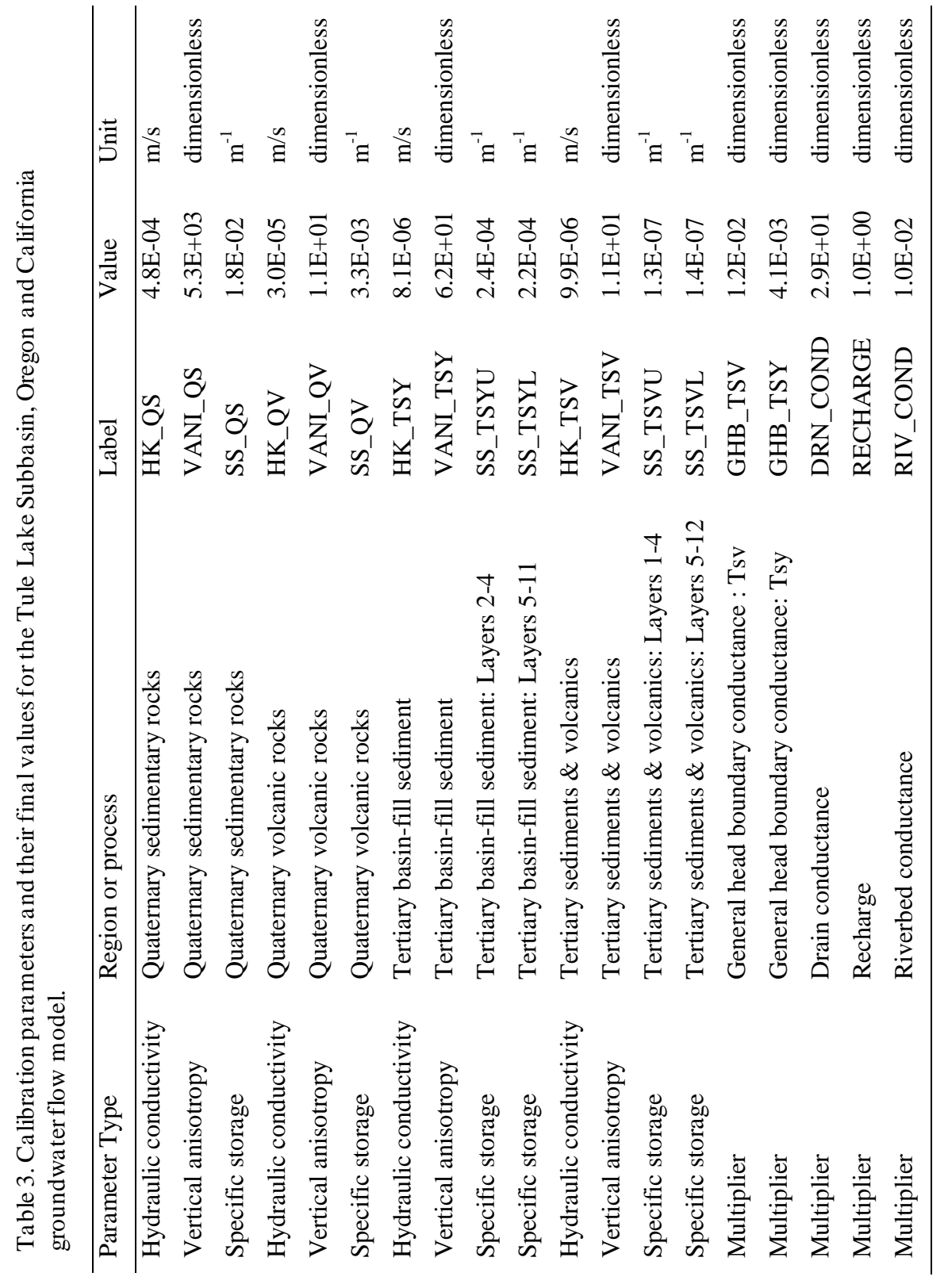


The vertical anisotropy parameter indicates the ease with which water can move vertically versus horizontally through a particular geologic zone; it is the ratio of the horizontal hydraulic conductivity to the vertical hydraulic conductivity. The greater the value, the more groundwater will preferentially flow horizontally. There is a 2 order of magnitude difference between the vertical anisotropy values within the Quaternary sediments for the regional and Tule Lake models $\left(1.76 \times 10^{1}\right.$ vs $5.29 \times 10^{3}$, respectively). This indicates that within the Quaternary sediments of the Tule Lake model, water is much less likely to flow vertically than in the regional model. The high value of vertical anisotropy is likely due to the character of the Quaternary sediments, which are fine-grained lake sediments. Lake sediments are typically laminated, which means that water is more likely to flow horizontally through them, rather than vertically. The higher value of vertical anisotropy in the Tule model versus the regional model makes sense because the less that water can flow down, the more water will be kept in that layer. Since Qs is in the top 25 feet of the model, the high vertical anisotropy helps to establish the observed downward vertical head gradient within the Tule Lake subbasin (higher heads in the shallow part of the aquifer, lower heads down deep). The regional model was not discretized to take advantage of data establishing the near-surface vertical gradient and was not as sensitive to the parameter.

The HK parameter, which is the lateral hydraulic conductivity, indicates how easily water is transmitted horizontally through a particular geology type. There is no explicit vertical hydraulic conductivity parameter in MODFLOW 2000; rather, the relationship between the horizontal and vertical hydraulic conductivity is defined through 
the VANI parameter (VANI = HK/Vertical hydraulic conductivity). The values for the hydraulic conductivity and vertical anisotropy of the Tertiary sediments of younger basins (HK_TSY, VANI_TSY) for the regional and Tule Lake models are different by one order of magnitude $\left(8.84 \times 10^{-5}\right.$ and $8.14 \times 10^{-6} \mathrm{~m} / \mathrm{s}$, respectively for HK_TSY, and $2.50 \times 10^{2}$ and $6.21 \times 10^{1}$, respectively, for VANI_TSY). Although the values are different, the ratio between them stays nearly the same. This means that the vertical hydraulic conductivity within the Tsy aquifer remains the same between the two models.

The specific storage parameter describes the volume of water that an aquifer releases from storage per unit decline in hydraulic head in the aquifer, per unit volume of an aquifer. There is a 2 order of magnitude difference between the specific storage value of the Tertiary sediments and volcanics of the regional model (SS_TSV3: $5.25 \times 10^{-5} \mathrm{~m}^{-}$ ${ }^{1}$ ), and the specific storage of the same unit (both upper and lower portions) in the Tule Lake model (SS_TSVU: $1.29 \times 10^{-7}$ and SS_TSVL: $1.38 \times 10^{-7} \mathrm{~m}^{-1}$ ). The storativity of the aquifer in each layer is derived from the specific storage by multiplying it by the layer thickness. In this way it is difficult to compare specific storage values between models, since the layer thicknesses can vary greatly between models; this is certainly the case between the Tule Lake and Klamath regional model. It is more useful to investigate the storativities themselves. When the storativity of the portion of each layer that is composed of Tsv is calculated, values range from $1 \times 10^{-6}$ to $3 \times 10^{-5}$. This is a reasonable range for storativities in a confined aquifer (Freeze and Cherry, 1979). 
Model Fit

The fit between simulated values that the model produces and observed values can be determined using various methods, including the graphical inspection of observed and simulated head plots, which is discussed later in this section. In addition to graphical methods, there are statistical methods that can be used to determine if there are systematic errors in the model. These methods are described below.

As discussed previously, the least-squares objective function (Eq. 1) used in the MODFLOW parameter-estimation process is a useful tool for assessing model fit, but is limited with regards to understanding error and bias in the model. To understand error and bias in the model, it is useful to evaluate the patterns of model residuals (the difference between observed and simulated values - in this model, hydraulic head values). It is desirable for model residuals to be random and normally distributed. One way to evaluate residuals is a plot of weighted residuals versus weighted simulated values (Figure 16) (Hill, 1998). 


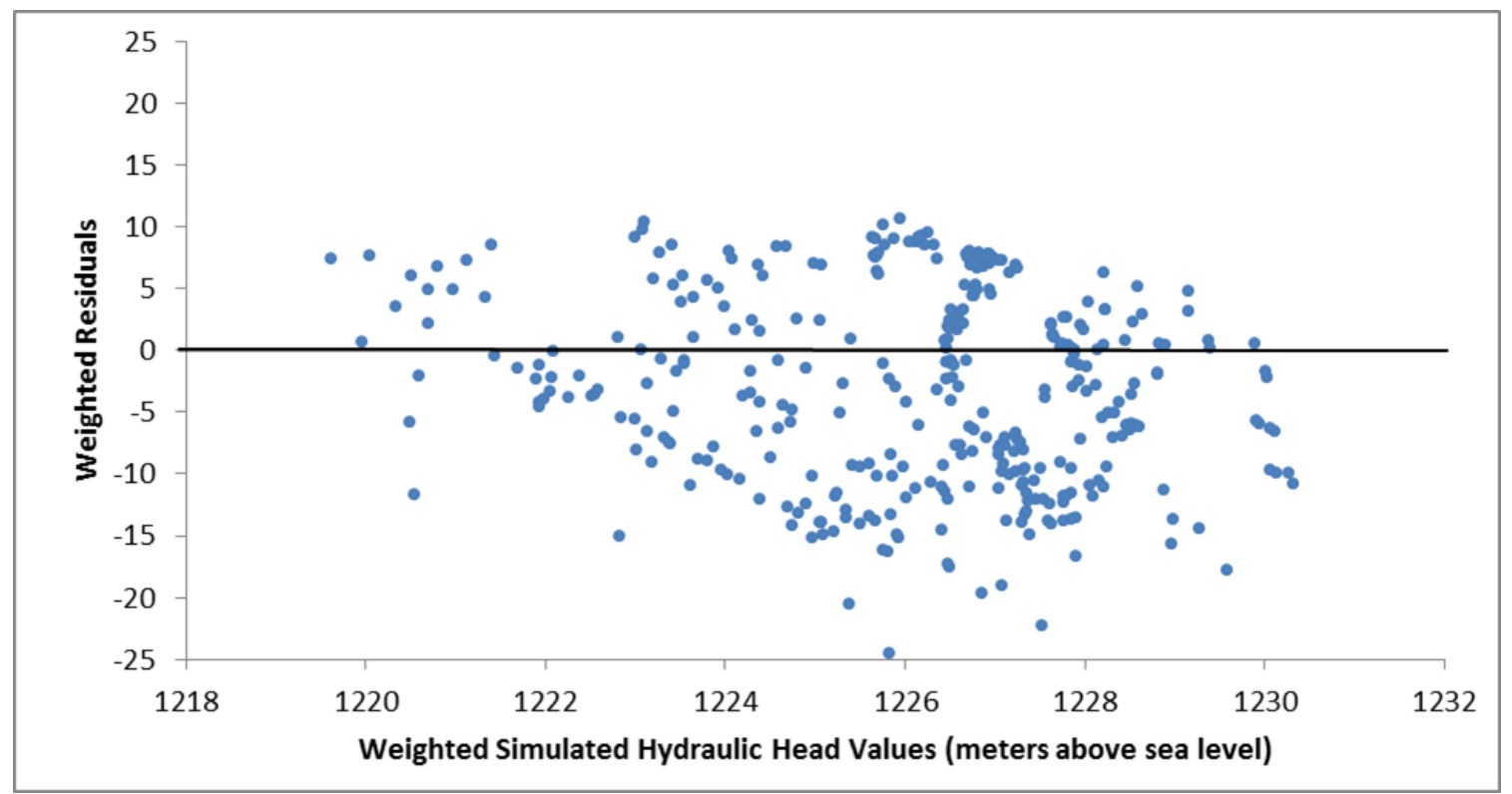

Figure 16. Weighted residuals vs. weighted simulated hydraulic head values.

Ideally, there should be no correlation between weighted simulated equivalents and weighted residuals. As can be seen in Figure 16, the data are generally spread evenly above and below zero with a slight negative bias. A negative bias indicates that simulated head values tend to be too high. This bias may be an artifact of model discretization. It may also be an artifact of the fact that in this model, the climate signal was not modeled. This could lead to simulated values that are higher than what they are in reality.

Another way to understand model fit is to evaluate the calculated error variance, standard error, and fitted standard error of the regression. These statistics provide means of assessing the average magnitude of model residuals (Hill, 1998). The calculated error variance, $\mathrm{s}^{2}$, is calculated as

$$
s^{2}=\frac{S(b)}{(N-N P)}
$$


where,

$\mathrm{S}(\mathrm{b})$ is the objective function value calculated using equation (1);

$\mathrm{N}$ is the number of observations;

NP is the number of estimated parameters (Hill, 1998).

The standard error of the regression, s, is the square root of the calculated error variance. The smaller these values are, the closer the fit is to observed data. For the Tule Lake model, the calculated error variance, $\mathrm{s}^{2}$, is 71.4 . The standard error of the regression, $\mathrm{s}$, is 8.5. Once calculated, the standard error of the regression can be used to calculate the fitted standard error of the regression. This statistic is a more intuitive means of understanding the average magnitude of residuals (Hill, 1998). The fitted standard error of the regression is the product of the standard error of the regression and the statistic used in determining the weights. In the Tule Lake model, the statistic used to calculate weights was 0.3 meters $(1 \mathrm{ft})$. The resulting fitted standard error is 2.6 meters $(8.5 \mathrm{feet})$. This means that over the entire active model domain, the average difference between observed and simulated hydraulic head is 2.6 meters ( 8.5 feet).

Graphical Comparison of Observed and Simulated Heads

A goal in model calibration is to find an acceptable fit between hydraulic head values simulated by the model and field measured (observed) heads. A selection of head plots for the observation wells are shown below (all observed and simulated head plots can be seen in Appendix A). The observed values are shown with a red line, and the simulated values are shown with the blue dashed line. Focus was placed on calibrating to 
springtime values of observed hydraulic head in order to match long-term trends in the data. Many short-term fluctuations in the observed heads reflect stresses which could not be accurately simulated in the model because of incomplete information on the geographic location and timing of pumping stresses (this is discussed further later in this section).

In nearly all of the observation wells (Figure $17 \mathrm{~A}-\mathrm{I}$ ), the long-term decreasing trend in hydraulic head is captured by the model. In many of the plots, there is groundwater recovery seen after 2007 . The recovery is likely due, at least in part, to underestimates in pumping in 2008 and 2009. In those years there was no supplemental groundwater purchased by Reclamation or KWAPA. However, it can be seen in observed head data that there is a pumping signal during the irrigation seasons of 2008 and 2009 that indicates that groundwater pumping still took place. Pumping stresses not included in the model that exist in reality will result in the recovery of simulated groundwater levels not seen in observed data.

There is also a probable climate signal not accounted for in the model. To simplify the model, average recharge was assumed, except in 2001 and 2010 when, in fact, a drying trend was observed in the Upper Klamath Basin. There may be less recharge to the groundwater system over time, causing (at least in part) the declines seen in water levels in wells in the Tule Lake subbasin. Hydrographs of wells that are in the Klamath Basin but outside of areas affected by groundwater pumping show declines over time (Figure 18 and Figure 19). Figure 17, B-F exhibit simulated post-2006 hydraulic head recovery. 


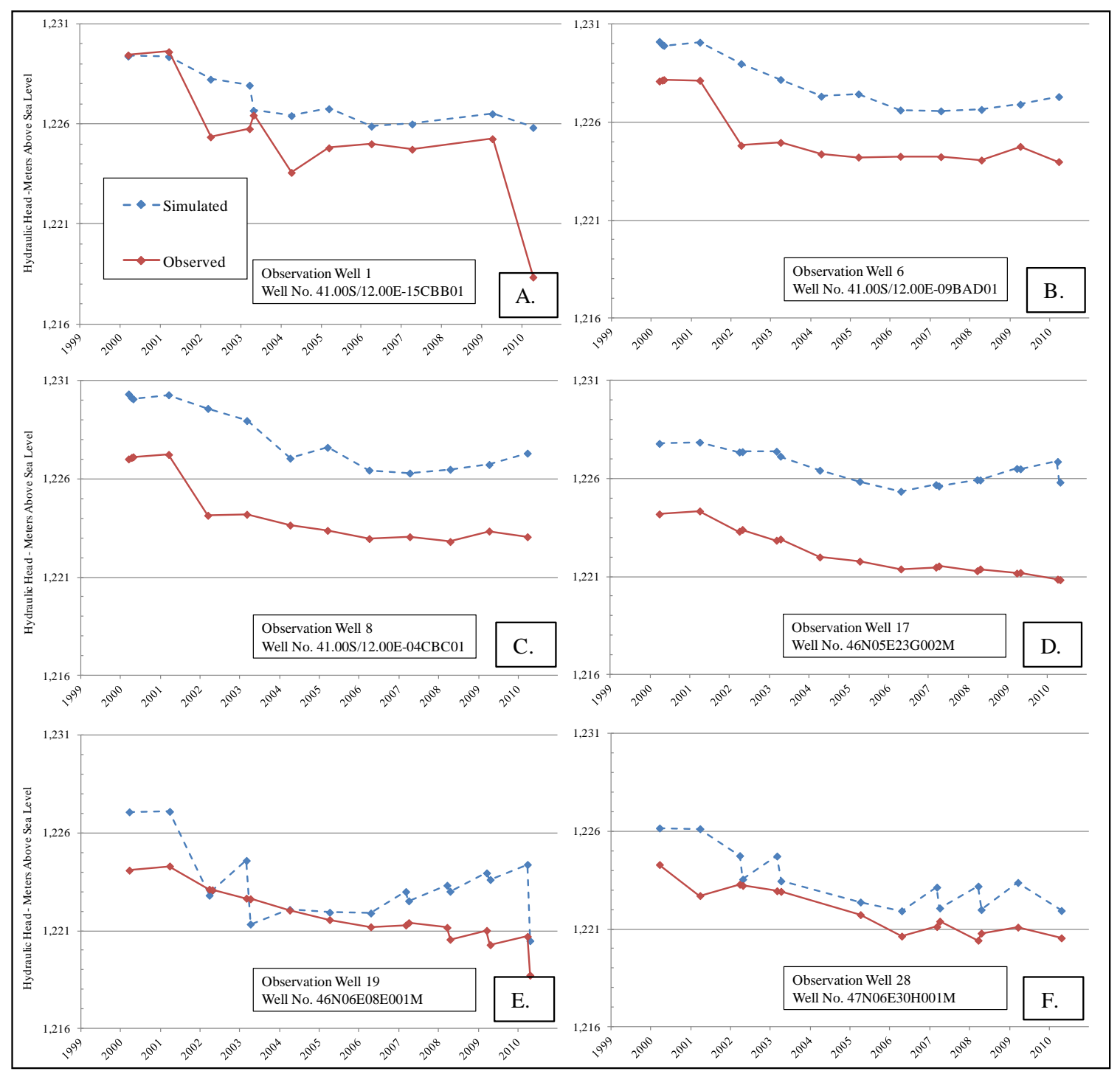




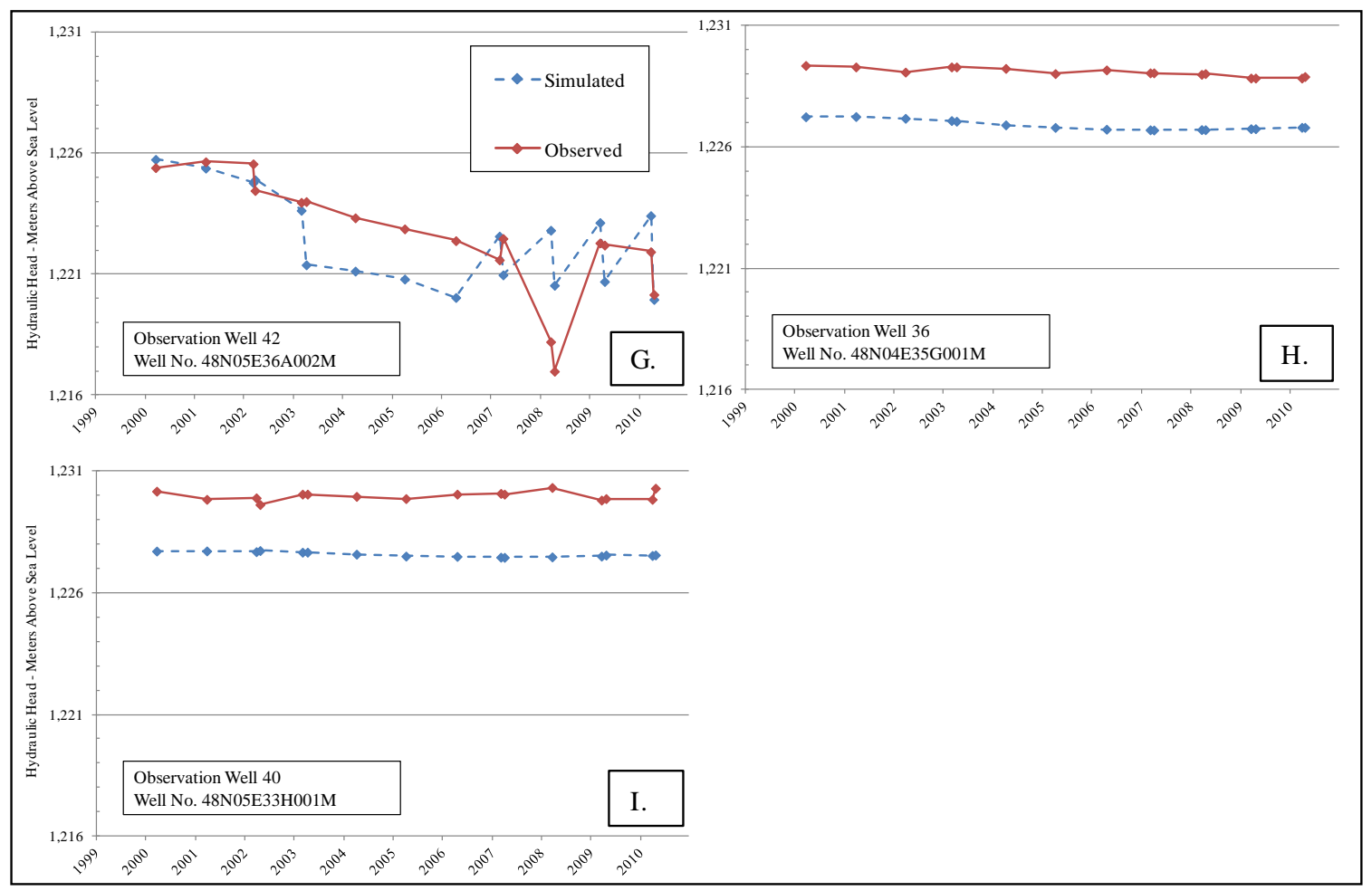

Figure 17 (A - I). Observed and simulated hydraulic head plots for a selection of model observation wells. Observed values are shown in solid red, and simulated values are shown in dashed blue. 


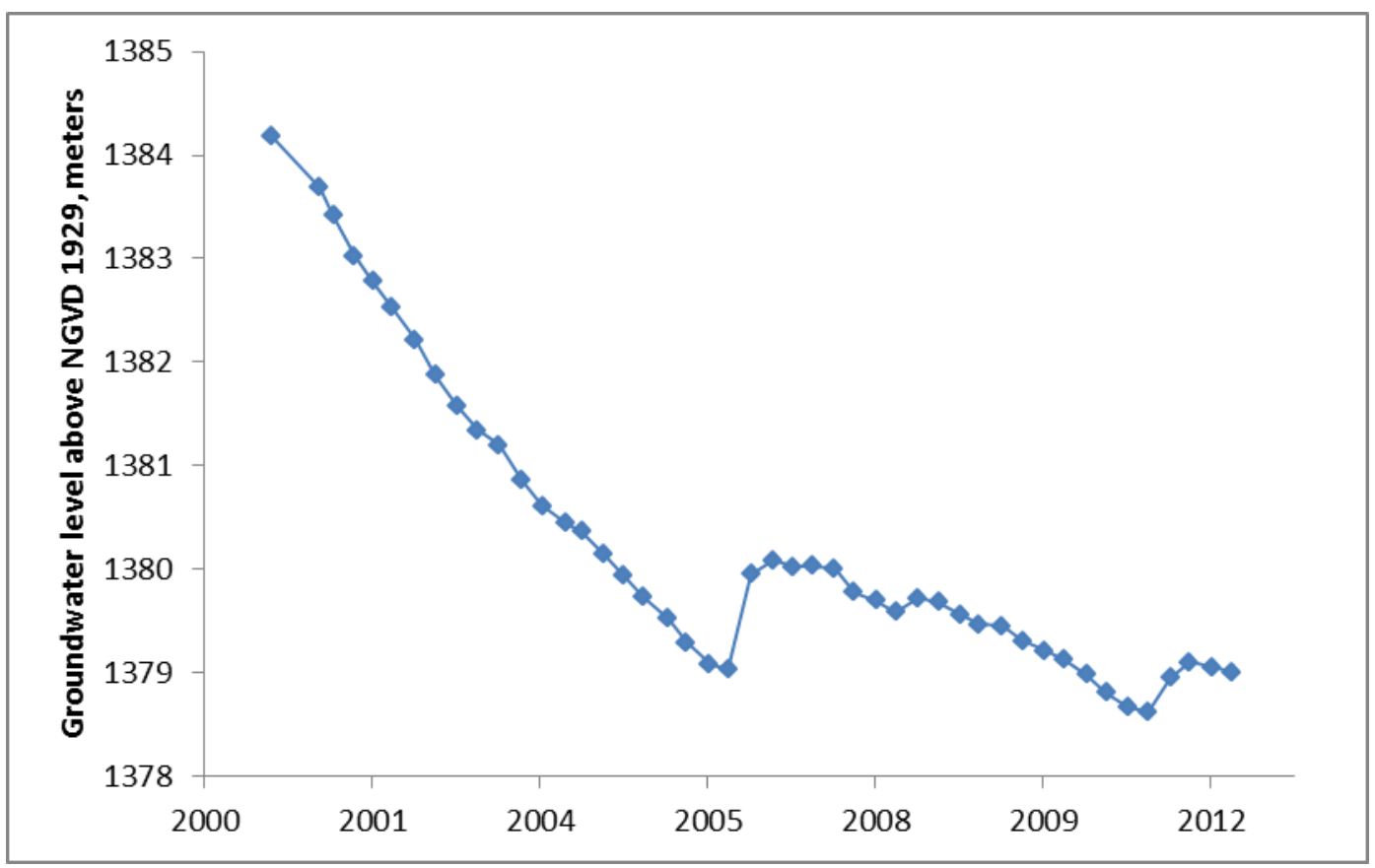

Figure 18. Water levels in USGS observation well 430837121473201, 28.00S/08.00E-17DBC01.

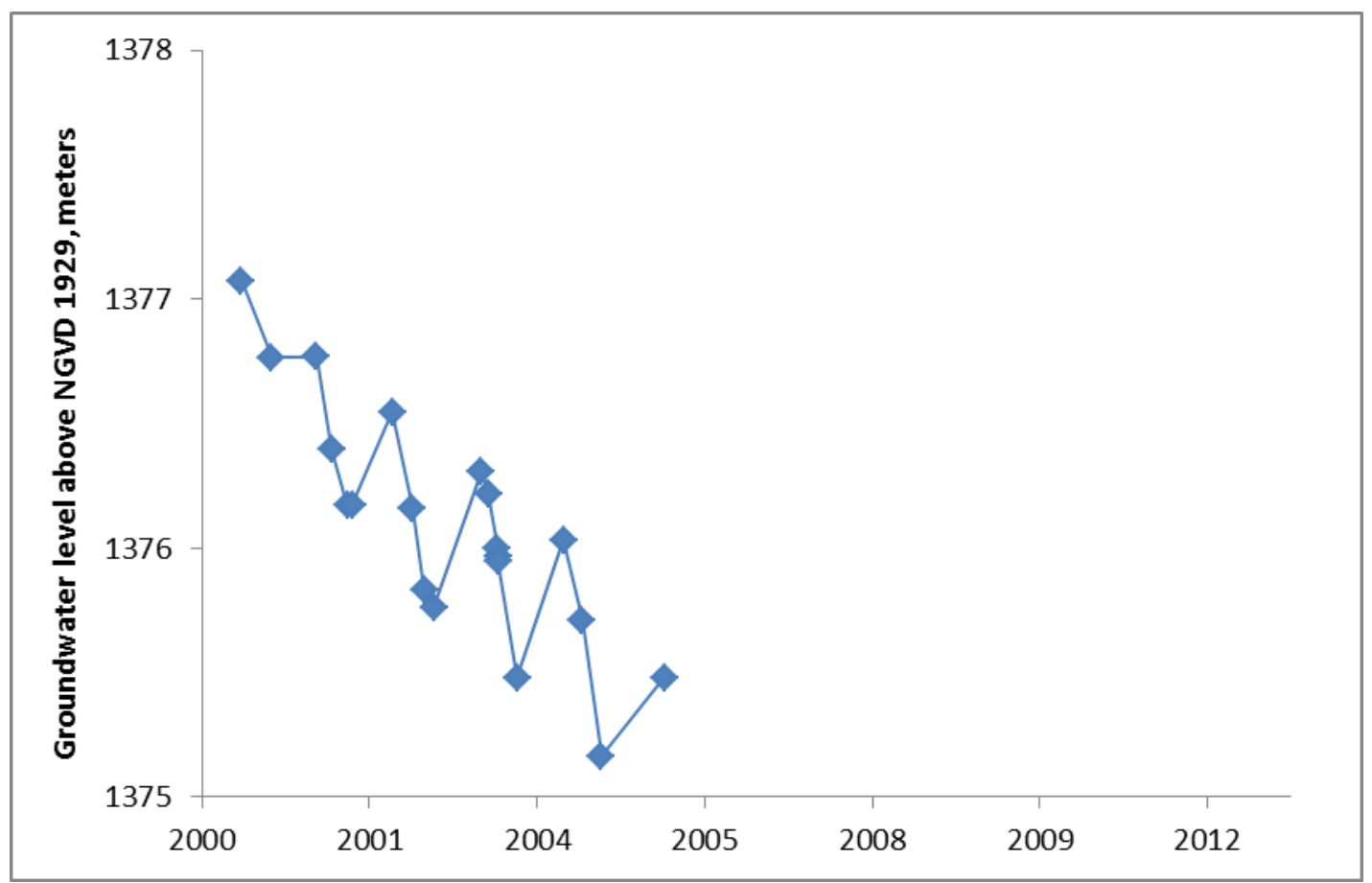

Figure 19. Water levels in USGS Observation well 430055121401501, 29.00S/09.00E-32DBA01 
In some wells there is a difference between the observed and simulated heads in the timing of drawdown and recovery. This likely has to do with uncertainty in the pumping data. The pumping rates for wells were provided during certain years as either an annual total for all wells or as totals for individual wells or groups of wells. The seasonal distribution of pumping is generally not known. This introduces error into the timing and spatial distribution of pumping. Simulated observation wells reflect the effects of this estimated pumping, for which the exact timing and rate of pumping are not known. Another potential cause of the difference in observed and simulated drawdowns and recovery is localized canal recharge. Recharge from irrigation in the model is distributed evenly over the irrigation district. In reality there are irrigation canals that provide localized recharge to the groundwater system. Shallow wells located near leaky canals will show a signal from this recharge in their hydrographs. This is a stress that is not included in the model.

\section{Simulated Hydrologic Budget and Sources of Water to Wells}

The overarching goal of this investigation is to quantify the changes that have occurred to agricultural drains due to groundwater pumping. A groundwater model is a useful tool in answering this question because it synthesizes a variety of data so that changes in a groundwater system can be quantified given a basin's particular geology, geometry, and pumping regime. In particular, a groundwater model can be used to quantify the changes in groundwater flow to model boundaries such as groundwater storage, drains, rivers, lakes, and margins between basins. 
Groundwater flux to and from the model boundaries is described by the hydrologic budget of the model. The hydrologic budget is a summary of all inflows and outflows to a model and provides key insights into the sources of water to wells. In MODFLOW, this is termed the volumetric budget (McDonald and Harbaugh, 1988). A volumetric budget is created for each stress period of the model simulation. Average volumes for each year of the simulation were calculated as a weighted average based on quarterly stress period.

The interplay of budget components are illustrated in Figure 20, which shows instantaneous rates of groundwater movement at the end of each stress period from elements of the volumetric budget for the Tule Lake model. It is interesting to note the way that groundwater storage changes through time. Storage as it is represented in the plot can be thought of as "net" storage, and indicates if storage is a source of water to wells or if it is a sink for groundwater. When storage is positive in the plot, it indicates that storage is a source of water to wells, and that there is not enough recharge to raise hydraulic heads in the aquifer, leading to groundwater level declines. When storage is negative, it indicates that water is entering storage and that hydraulic head in the aquifer is rising. This becomes more intuitive upon inspection of the plot. It can be seen that when groundwater pumping is at its greatest, the storage term is also the most positive, meaning it is a source of water to wells. It makes sense that during times of large withdrawals of groundwater, storage would be a relatively large source of water. In 2001 this is the case, and in the first few years of supplemental pumping, storage is positive, indicating it is a source of water to wells. Over time this changes, until 2008-2009 when 
storage becomes a sink for groundwater. There are likely two reasons for this change. One is that groundwater pumping, over time, decreased until 2009. The other reason is that, over time, groundwater pumping had effects on surface water features. As discussed previously, as pumping occurred and continued through time, a cone of depression formed around each well being pumped that intercepted groundwater that would otherwise flow to surface water features (Theis, 1940). Figure 20 shows the change from storage being a dominant source of water to wells (a large positive storage value) to other model boundaries being the major source. In the Tule Lake subbasin, other boundaries include drains, the Lost River, the Tule lake sumps, and interbasin flow boundaries.

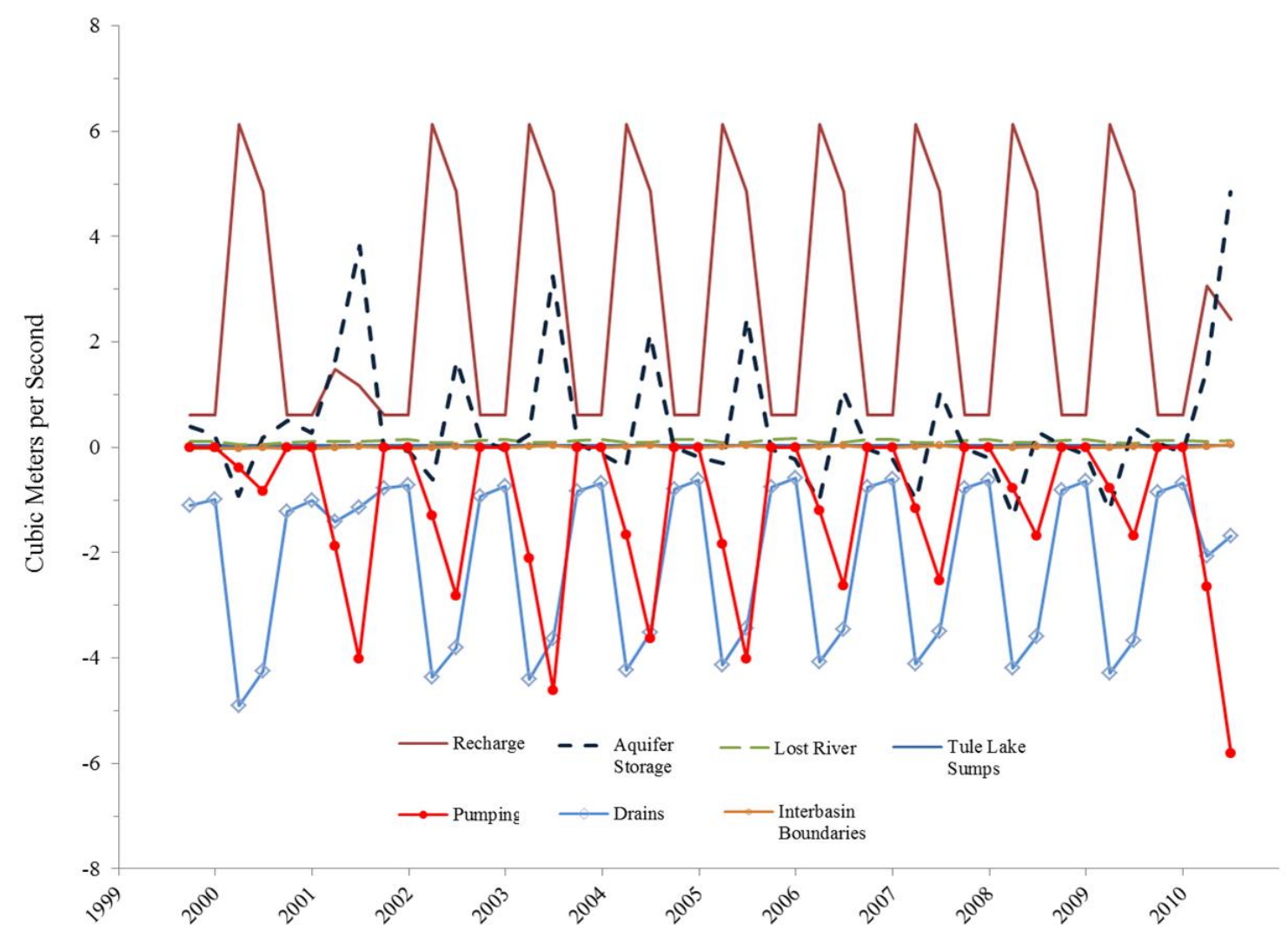

Figure 20. Instantaneous rates of budget components at the end of each stress period of the Tule Lake model. 
The question then is, which boundaries are being impacted by pumping and to what degree? To answer that question, the cumulative volumes of annual change in each component of the water budget can be compared (Figure 21). As a reference, the cumulative well pumpage over the model simulation is shown. It appears that over time, the boundaries that are the most impacted by groundwater pumping are agricultural drains and storage. The Lost River, interbasin flow boundaries, and Tule Lake sumps contribute a comparatively small portion of water to wells over the model simulation.

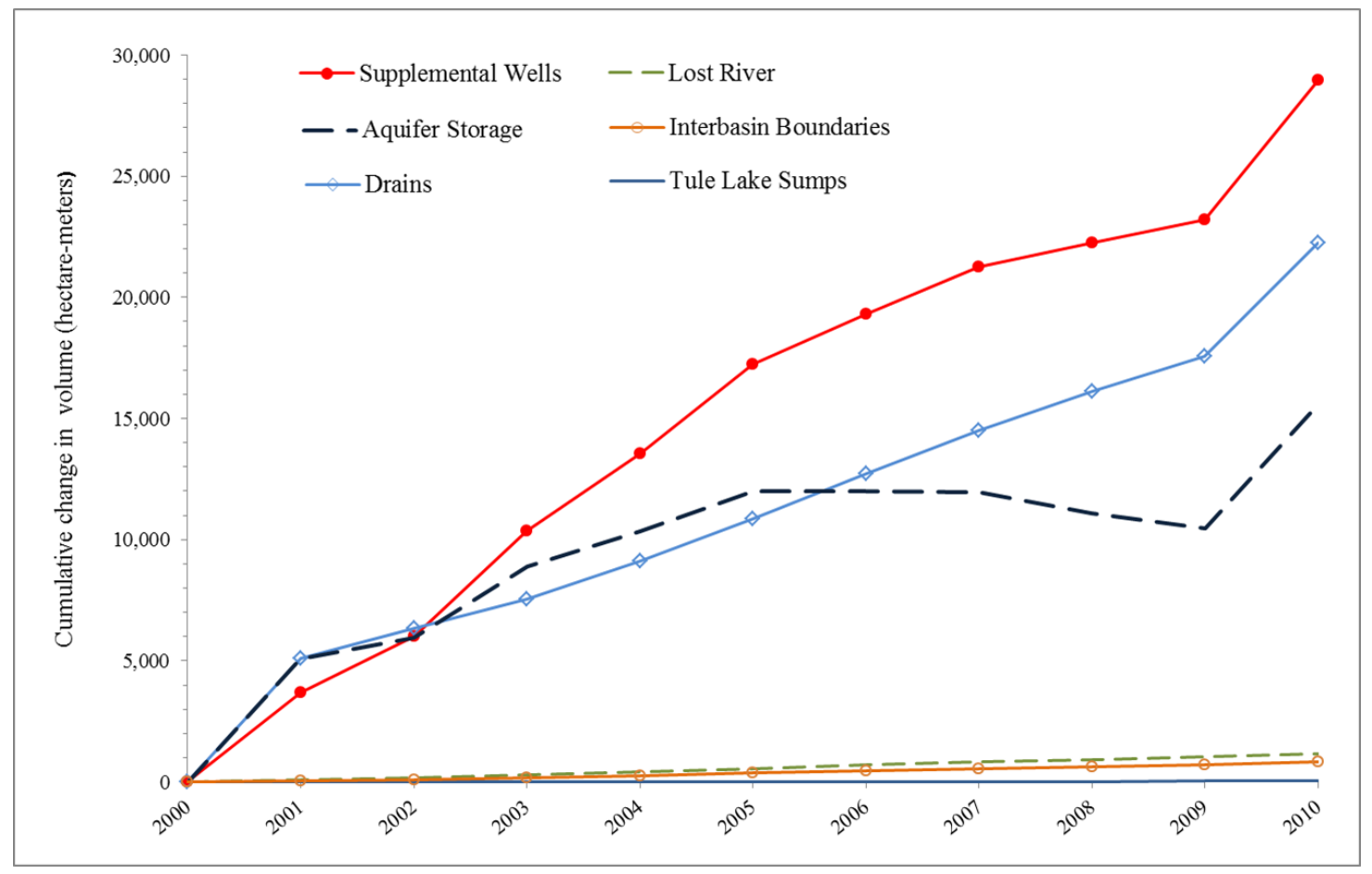

Figure 21. Cumulative change in volume of selected budget components of the Tule Lake model.

If pumpage were the only stress to the model, the cumulative change in each boundary and changes in storage would add up to the total pumpage. As can be seen in Table 4, this is not the case; the impact due to boundaries is approximately 10,878 hectare-meters higher than the total cumulative volume pumped from wells. This is due 
to changes in recharge. For nearly the entire model simulation, recharge is kept constant. It is reduced in 2001 and 2010 to account for decreased recharge due to reduced irrigation diversions. The reduction in recharge acts as a stress to the groundwater system and affects every boundary, in addition to the pumping stress. In 2001 the reduction in modeled recharge was 6604 hectare-meters, and in 2010 it was 4345 hectare-meters, for a total reduction of 10,949 hectare-meters. Once this change in recharge is factored in, the model budget balances to within about 0.2 percent.

Table 4. Cumulative change in Tule Lake model volumetric budget.

\begin{tabular}{ccc}
\hline \multirow{2}{*}{ Budget Element } & $\begin{array}{c}\text { Cumulative Change } \\
\text { in Element }(\mathrm{h}-\mathrm{m} / \mathrm{yr})\end{array}$ & Totals \\
\hline Supplemental Pumping & 28960 & 28960 \\
\cline { 2 - 3 } Aquifer Storage & 15543 & \\
Drains & 22262 & \\
Lost River & 1168 & 39838 \\
Interbasin Boundaries & 838 & \\
Tule Lake Sumps & 28 & \\
\cline { 2 - 3 } & \multicolumn{2}{c}{ Difference } \\
\hline
\end{tabular}

Groundwater pumping causes the greatest impact to agricultural drains. To understand the absolute impact to drains and the percentage of pumping supplied by drains, the loss in drain flow over time can be plotted. The maximum loss in drain flow from pre-2001 drain flow occurs in 2006, with a loss of 1,852 hectare-meters per year. This is approximately 56\% of the average 2001-2006 supplemental pumping of 3,215 hectare-meters per year. In other words, by 2006 approximately 56\% of the water coming from wells was water that would have flowed to drains if pumping were not occurring. It is important to note that the losses to drain flow in 2001 and 2010 are anomalous. Drain 
losses those years reflect both increases in pumping and loss of recharge due to decreased irrigation deliveries and precipitation. The effects of pumping take time to propagate to boundaries (Barlow and Leake, 2012). A more accurate representation of the integrated effect of pumping on drain flow over time is a plot with 2001 and 2010 data points either averaged or removed, as presented in red in Figure 22.

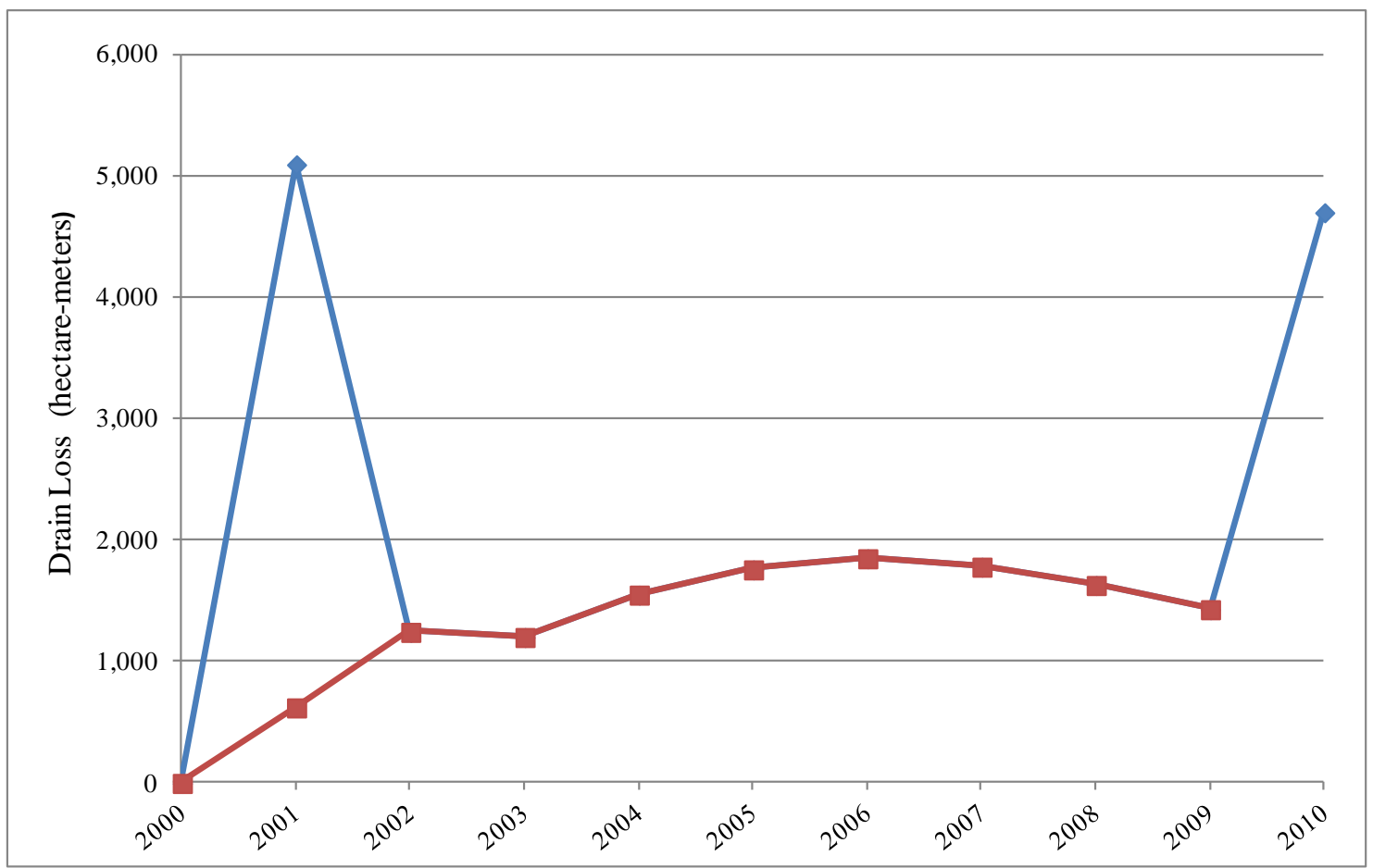

Figure 22. Loss of discharge to drains, in hectare-meters per year, calculated as the difference between the discharge to drains in 2000 and discharge in subsequent years. Blue line is drain loss with 2001 and 2010 data included; red line is the drain loss plot with an averaged 2001 data point and no 2010 data point. 2001 and 2010 are anomalous years; spikes in drain loss those years reflect a marked decrease in recharge as well as increased pumping. The full, integrated effect of pumping in drain flow is shown more clearly in the slow rise of the red plot. The maximum loss in drain flow occurs in 2006, when the impact to drains is 1,852 hectare-meters, which is 57\% of the average annual 2001-2006 supplemental pumping of 3215 hectare-meters per year.

Like the simulated and observed hydraulic heads, the simulated and observed loss in drain flow can also be compared (Figure 23). The observed loss in drain flow is calculated from the summed loss in drain flow for the North KID/TID, Lease Lands, and 
Copic Bay subareas of the Tule Lake subbasin. To calculate drain flow loss, the observed drain flow in 2000 was taken to be the base, pre-pumping condition, and the drain flow for each subsequent year (up to 2010) was subtracted from the 2000 value. This is the same way that drain loss was calculated for the simulated drain flow data. The plot shows that the drain losses in 2001 and 2010 were significantly greater than what are modeled. However, there is a similar magnitude to the overall, gradual change in drain flow, which is more indicative of the effects of pumping. Modeled drain flows show a maximum impact in 2006 of 1,852 hectare-meters per year. Observed drain loss reaches a maximum of 3,031 hectare-meters per year in 2007. The difference between observed and simulated drain flow loss may be attributable to the influence of factors other than pumping affecting drain flows, or uncertainty in the drain data analysis. There may still be some double counting of water that could explain the higher values. Also, the only quantifiable source of surface water available for this analysis was the spill from KID. The difference in timing of maximum impact to drains could be due to the effect of a decline in recharge due to a climate signal not simulated in the model, or it may have to do with error in the timing and/or magnitude of modeled pumping.

Based on a comparison of the observed and simulated drain flow losses, and taking into account the uncertainty in both the model and the drain flow analysis, it appears that a loss of drain flow in the thousands of hectare-meters per year occurs within the first 6-7 years of supplemental groundwater pumping. 


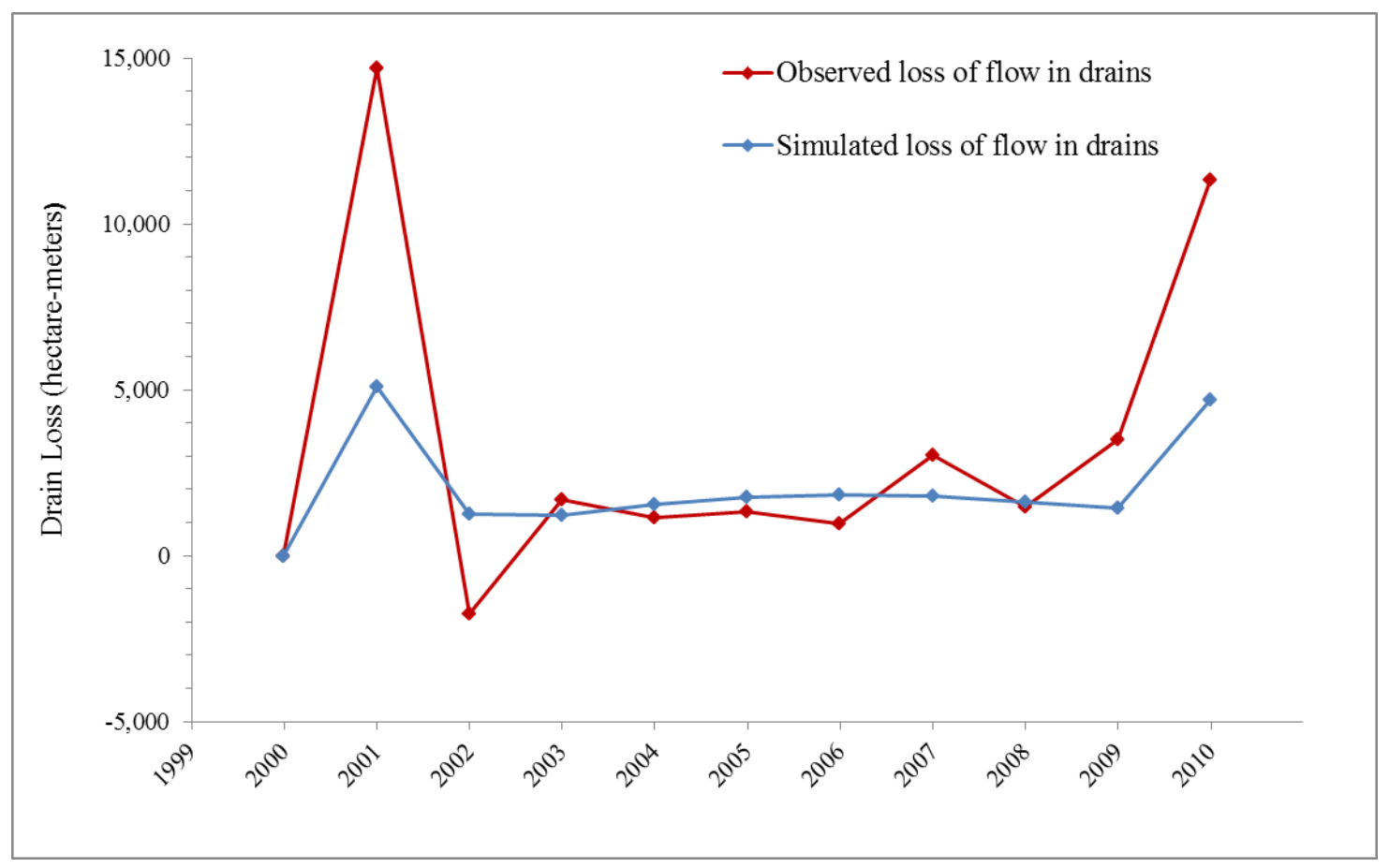

Figure 23. Observed and simulated loss in flow to drains. Observed loss in flow to drains is calculated from the total drain loss from all 3 subareas of the drain flow analysis. To calculate drain flow loss, the observed drain flow in 2000 was taken to be the base, pre-pumping condition, and the drain flow for each subsequent year (up to 2010) was subtracted from the 2000 value. Note: in 2002 the drain flow loss is negative; this indicates that the 2002 drain flow was higher than it was in 2000.

The maximum modeled impact to drains can be plotted spatially (Figure 24).

Darker colors in the figure represent a greater decrease in the amount of groundwater that discharges to drains. The greatest decrease in discharge to drains occurs in the north and southeast portions of the study area. This is consistent with the results of the KID/TID drain analysis, in which a majority of the impact to drains was observed in the northern and southeastern subareas within the study area. Also included in this plot are the modeled pumping wells. There is a noticeable correspondence between drain impacts and areas where groundwater is pumped. 


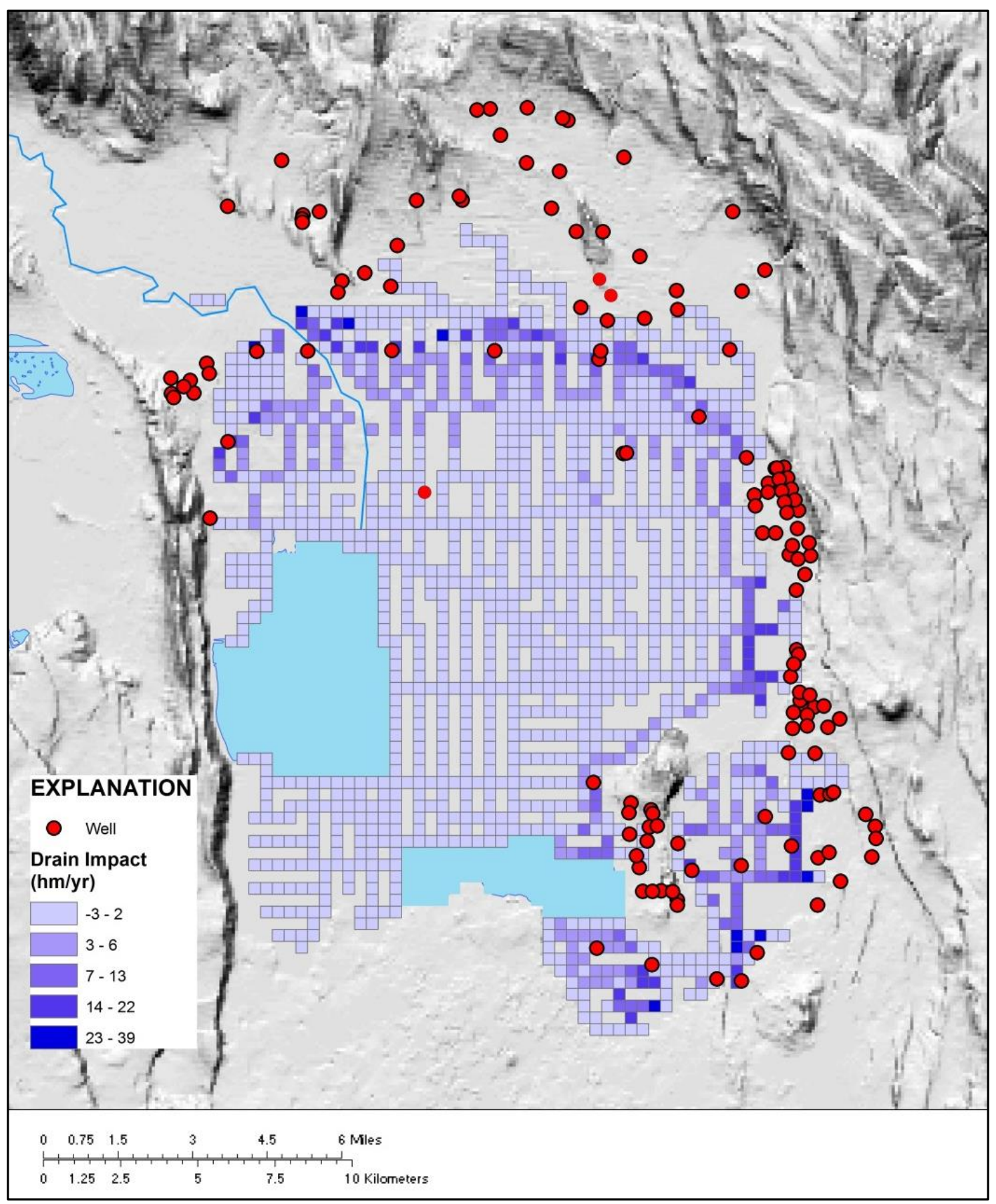

Figure 24. Modeled spatial distribution of impacts to drains, in hectare-meters per year, calculated as the discharge to drains in 2006 (the year of maximum drain impact) subtracted from the discharge to drains in 2000. Since discharge to the drains represents a loss of water from the aquifer, the discharge volumes used in the calculation are negative. 
Influence of Interbasin Groundwater Flow

Simulations indicate that interbasin margins do not contribute a significant

amount of water to wells. As can be seen from Table 3, the cumulative total change in the flux through the interbasin margins is 838 hectare-meters compared with the cumulative pumping of 28960 hectare-meters. There is anecdotal evidence to suggest that at times in the past when the subbasin was inundated, water flowed out of the permeable basalt to the south, to the Pit River basin. Subsurface flow of groundwater out of the Tule Lake subbasin to the south is also evidenced by a southerly-sloping water table (Gannett et al, 2007). Quantifying the degree to which interbasin flow boundaries serve as a source of water to wells and how that has changed in response to pumping is important, because it has implications with regards to water management within the subbasin, which will be discussed in further detail in the Discussion section. To test the contribution of groundwater from adjacent subbasins, permeable boundaries were placed all around the active model domain. Specifically, the boundaries that correspond with the Tertiary basin-filling sediment (Tsy) and the regional aquifer below the basin-filling sediment (Tsv) were modeled as being permeable interbasin connections. The model was then calibrated with these permeable interbasin boundaries in place to see, when optimized, what the conductance of the general head boundary parameters would be. When fully calibrated, the conductances of the general head boundary cells are low (GHB_TSV: 1.2 $\mathrm{X} 10^{-2}$; GHB_TSY $\left.=4.1 \times 10^{-3}\right)$. To test the influence of the GHB cells on the modeled hydraulic heads, the conductances of the GHB cells were increased by one and two orders of magnitude in order to observe the effect on simulated and observed hydraulic 
heads. In both cases, the match between simulated and observed hydraulic heads is not as good as when conductances are low. A better match between simulated and observed heads when GHB conductances are low suggests that there is not a significant amount of water moving between subbasins. 


\section{Discussion}

The allocation of water between various uses within the Tule Lake subbasin has been challenging for resource managers. Groundwater has been used increasingly in the subbasin to make up for shortages due to reallocation of surface water for in-stream uses. There is evidence to suggest that increased groundwater pumping has affected agricultural drains in the subbasin by reducing the volume of groundwater that discharges to them. Agricultural drains, designed to carry away excess irrigation water that has percolated to the shallow subsurface, are an important source of water to downstream irrigators and are the primary source of water to both the Lower Klamath and Tule Lake National Wildlife refuges. As such, changes in the volume of water discharging to drains and the causes of that change are important to understand.

The question to be answered in this thesis then is, have drain flows decreased since supplemental pumping began in 2001 and if so, by how much? To answer that question, data from the Klamath and Tulelake Irrigation Districts (KID and TID) were analyzed to quantify how the groundwater component of drain flow has changed over time. Additionally, a groundwater model of the Tule Lake subbasin was constructed to synthesize data regarding pumping, geology, structure of the subbasin, and proximity of stresses to other boundaries such as drains, the Lost River, the Tule Lake sumps, and interbasin flow margins in order to quantify how the interplay of these variables manifest as changes to drain flow.

Results of the drain flow analysis indicate that groundwater pumping has caused changes in agricultural drain flow. Monthly time series data of volumes pumped from key 
pumps in three subareas of the Tule Lake subbasin were summed to create annual volumes pumped for each subarea. The only quantifiable source of surface water to agricultural drains is operational spill from KID. The yearly volume of KID spill to TID drains was subtracted from the TID pump volumes so that, as much as possible, the change in the groundwater component to drains could be quantified. What this analysis shows is that in all three subareas (North KID/TID, Copic Bay, and the Lease Lands), the groundwater component of drain flows has decreased to varying degrees. The greatest change occurred in the North KID/TID and Copic Bay subareas, with decreases of 2,750 and 900 hectare-meters, respectively, when compared with the 1997-2000 average drain pumpage. The Lease Lands showed a comparatively small overall change of 350 hectaremeters as compared with the 1997-2000 average. In total, the loss in the groundwater component of drain flow for all three subareas is approximately 4,000 hectare-meters.

The 4,000 hectare-meter difference between 1997-2000 average drain flows and 2012 flows likely reflects changes in recharge and in surface-water inputs that were not able to be quantified, such as over-land runoff from fields. Changes in recharge were probably the dominant force in reducing drain flows in 2001 and 2010, dry years in which irrigation diversions were curtailed. This is evident in an analysis of the observed yearly loss of groundwater flow to drains. There are large spikes in loss of groundwater to drains in 2001 and 2010, most likely due to reduced recharge, as discussed previously. A better indication of the effect of pumping on drain flow is the slow, gradual decrease in flow to drains; looking at this, the 2007 water showed the greatest difference (3031 hectare-meters) from the 1997-2000 average. 
Analysis of groundwater model results verifies an impact on drains due to groundwater pumping. Over the model simulation, changes in storage suggest that over time, the source of water to wells shifts from aquifer storage to agricultural drains. Modeled drain impacts reach a maximum in 2006 with a 1,852 hectare-meter per year loss compared to 2000. The Lost River, interbasin flow margins, and the Tule Lake sumps all provide a comparably small amount of water to pumping.

Looking at the drain flow analysis and the groundwater model results together, it can be concluded that an impact to drains is occurring due to groundwater pumping. Analysis of drain pump data indicates that by the late 2000s, the magnitude of the drain impact is in the thousands of hectare-meters per year compared to the 1997-2000 average. Simulations suggest that the impact to drains from supplemental pumping builds between 2001 and 2006, at which time 56\% of the post-2000 increase in supplemental pumping is sourced from drains. It appears that what is happening is that the groundwater system is slowly regaining equilibrium after the increased pumping stress since 2000. Over time, the contribution of aquifer storage to wells has diminished and the contribution of drains to wells has increased. These findings are entirely consistent with what is known about the behavior of groundwater systems that undergo pumping stress (Theis, 1940; Reilly and others, 2008; Barlow and Leake, 2012). Over time, a well's cone of depression expands outward and affects flow to surface water features such as springs, streams, and drains, or other aquifer boundaries. The well will then source a portion of its water from those surface water features. Through time, the proportion of water coming from aquifer 
storage diminishes until $100 \%$ of the water to wells is sourced from changes in groundwater flow to or from surface water features or other boundaries.

\section{Implications}

The upper Klamath Basin is a region in which there are many stakeholders in need of access to limited water resources. Activities that have potential effects on access to these resources are important to understand so that resource managers can continue to allocate water as effectively as possible.

Decreases in drain flow have potential implications for the Lower Klamath and Tule Lake National Wildlife refuges. Irrigation return flows delivered by agricultural drains are the main source of water for both refuges. For the years 2003-2005, the percentage of total inflow to the Lower Klamath and Tule Lake refuges that was irrigation return flow was 67\% and 75\%, respectively (Risley and Gannett, 2006).

Since the majority of water to both refuges is composed of return flow in drains, a reduction in this flow will have implications for both refuges. The Lower Klamath National Wildlife Refuge is not located in the Tule Lake subbasin; it is located just to the west. It is separated from the Tule Lake subbasin by Sheepy Ridge. The inflow to Lower Klamath NWR comes from two sources: the D Pumping Plant, which pumps water from the Tule Lake sumps through a tunnel in Sheepy Ridge, and the Ady Canal, which diverts water from the Klamath River, northwest of the refuge. The areas nearest to Sheepy Ridge, on the east side of the refuge, are better served with water from the D Plant. When the Ady Canal is the only source of water to the refuge, it is difficult to move water from 
the northwest portion of the refuge to areas that are served by water from the D Plant. If D Plant water decreases in availability and the Ady Canal becomes the primary source of water to the refuge, it may become necessary to install pumps in the refuge in order to lift water to more southerly parts of the refuge. Decreased inflow to Lower Klamath National Wildlife Refuge through the D Plant means that the refuge will be drier, which increases the likelihood of fire within the peaty soils of the refuge.

Fires, once within the peat soils, can smolder for months until rains put them out. Another impact of a drier refuge is that waterfowl will be more densely packed on ponds that have diminished in size due to lack of water. Diseases such as avian cholera and avian botulism will then be able to spread more quickly among bird populations concentrated in smaller areas. There are also implications for the Tule Lake NWR. As drain flow decreases and the need for water to be pumped through the D Plant diminishes, salinity could increase within the Tule Lake subbasin since the system will not be flushed as frequently as it once was (Tim Mayer, U.S. Fish and Wildlife Service, oral. commun. 2014).

In addition to the refuges, diminished drain flows could also have implications for downstream irrigators and the Tulelake Irrigation District. To date, growers who irrigate primarily with Project return flow transmitted by the drain system have not been affected by decreases in drain flow. Further reductions in drain flow may take place, and further changes may have implications for TID; less water available could mean that changes in District operation will be necessary to provide as much water as possible to farmers. Recent management modeling by Wagner and Gannett (2014) suggests that prohibitive 
drawdown would likely limit pumping before drain flows were diminished to the point that there would be insufficient water to irrigate lands in the southern part of the Project.

The results of this study also have implications for the Klamath Project in a broader sense. An agreement among stakeholders in the upper Klamath Basin, known as the Klamath Basin Restoration Agreement (KBRA) was completed in 2010. The objective of the KBRA is to balance the benefits of water for both aquatic wildlife and agriculture. The KBRA defines measures for defining and limiting the "adverse impacts" of on-Project groundwater pumping on streams and springs in the upper Klamath Basin. The KBRA defines adverse impacts as a 6 percent or greater reduction in groundwater discharge to various surface-water features in the subbasin, including the Klamath River (KBRA, 2010). Results of the groundwater model show that the effects to surface-water due to increases in supplemental groundwater pumping on the Project occur locally to the drains in the Project area. Model calibration suggests that there is little flow that occurs between subbasins. Therefore, the effects to surface water are unlikely to propagate outside the Project and affect KBRA-listed surface water features.

\section{Study Limitations}

Uncertainty exists in any study and should be understood so that the interpretation of study results is done appropriately. The limitations of this study will be discussed in the following section. 


\section{Uncertainty in Drain Flow Analysis}

The data in the drain flow analysis, i.e. time series of volumes pumped from agricultural drains, is collected based on the operational needs of the Project or the irrigation districts. Estimates of volumes pumped from drains are determined using the pump rating and time of operation of each pump. Volumes of operational spills are determined using weirs and spill points. Water depths at weirs are sometimes estimated visually (Mark Stuntebeck, KID, oral commun. 2013). As such, there is uncertainty associated with these measurements.

The method by which changes in groundwater discharge to drains was estimated from pump data also introduces uncertainty. Water is pumped from the drains and reused in parts of the subbasin, so the drain flow analysis focused on three subareas with drain pumps that best integrate flow for each respective subarea in order to avoid doubleaccounting of drain flow. However, some drain flow may still be accounted for more than once. Finally, the only quantifiable source of surface water available for this analysis was operational spill to drains from KID. There may be other sources of surface water to drains, such as over-land flow from precipitation or from direct runoff from fields. Changes in unaccounted surface-water sources in this analysis could potentially affect estimates of the changes in the groundwater component of drain flow.

\section{Uncertainty in Groundwater Model}

Groundwater models are representations of complex natural systems. As such, simplifications must be made in order to create a groundwater model. The subsurface geology of the Tule Lake subbasin is variable and is unknown to a large degree, so it 
must be simplified and its structure inferred where data are scarce. For example, there are no independent measures of the boundary flux of groundwater into the Tule Lake subbasin from adjacent subbasins. The final structure of the interbasin flow boundaries was determined via experimentation during model calibration. There was also uncertainty in the data used in the model. Specifically, there is uncertainty in the recharge and pumping data. Recharge in the model is based on an estimate from a report by the ITRC, which is itself based on uncertain data (Burt and Freeman, 2003). However, it is presently the best data available on recharge in the upper Klamath Basin. The pumping data used in the model is somewhat imprecise; the spatial distribution and seasonality of the pumping are poorly known. Additionally, there is unmeasured pumping that took place, as evidenced by supplemental pumping signals in well hydrographs during 2008 and 2009, years when there was no stated supplemental pumping. In addition to data uncertainty, there were processes that were not able to be simulated with the model. The stresses that were not simulated were the decadal climate signal present in the upper Klamath Basin, and localized recharge from leaky irrigation canals. While evapotranspiration was not explicitly defined in the model, it was taken into account in the recharge volume.

\section{Next Steps}

The work presented here gives the magnitude of change in drain flow due to groundwater pumping since its increase in 2001. To further monitor and potentially quantify the changes that are taking place to the groundwater system of the Tule Lake subbasin as a result of groundwater pumping, there are refinements to data collection and data storage that could be made. Suggestions for changes are presented below. 
To better quantify the changes to the hydrologic budget of the Tule Lake drains since groundwater pumping increased in 2001, uncertainty in the volumes spilled to and pumped from the TID drain system could be measured with more accuracy. The best data available as of this writing (2014) are monthly pump and spill volumes from TID and KID, respectively. These data are gathered for district purposes and provide a magnitude of change, but have large uncertainty for the type of analysis presented here. To mitigate this uncertainty, one recommendation would be to measure drain flow and operational spill directly, using flow-meters. This would provide a measurement of drain flow and operational spill volume with a smaller, quantifiable margin of error.

In addition to understanding the change in the surface component of flow and how it changes in response to pumping, it is important to understand how the water table changes as groundwater pumping increases. To assess changes to the water table, a system of monitoring wells could be installed in the subbasin. In addition to installing monitoring wells to assess potential changes in drain flow, monitoring wells could also be installed near the shared boundary between the Tule Lake and Lower Klamath subbasins in order to better understand how pumping in the Tule Lake subbasin affects the rate of interbasin flow from the Lower Klamath subbasin. This is an important question; groundwater from the Lower Klamath subbasin could potentially be a source of water to drains, and this could have implications for the KBRA.

If future groundwater modeling exercises are done within the upper Klamath Basin, there are a few suggestions that may aid in the quantification of impacts to surface-water due to groundwater pumping. Data are scarce in the Tule Lake subbasin 
with regards to subsurface geology. Streamflow depletion is highly dependent on the hydrogeologic characteristics of the material that groundwater moves through, so a better understanding of the geology would focus the understanding of the timing and magnitude of impacts to surface water.

Improvements could also be made to the pumping data. In the groundwater model presented here, the pumping data set was, in some cases, generalized for sets of wells. The timing and spatial distribution of pumping was unknown. To further focus the understanding of the impacts to drains due to pumping, time series data for individual wells would be very helpful. Another improvement that could be made with regard to pumping data would be the creation of a data repository for well data in the upper Klamath Basin. The compilation of the groundwater model presented here required well data from OWRD, CDWR, USGS, and Reclamation. Data consistency and retrieval would be improved if all well data were either collected by a single agency or stored in a central repository. 


\section{References}

Adam, D.P., Bradbury, J.P., Rieck, H.J., and Sarna-Wojcicki, A.M., 1990, Environmental changes in the Tule Lake basin, Siskiyou and Modoc Counties, California, from 3 to 2 million years before present: U.S. Geological Survey Bulletin 1933, 13 p.

Anderson, M.P., and Woessner, W.W., 1992, Applied groundwater modeling Simulation of flow and advective transport: Academic Press, San Diego, 381 p.

Barlow, P.M., and Leake, S.A., 2012, Streamflow depletion by wells - Understanding and managing the effects of groundwater pumping on streamflow: U.S. Geological Survey Circular 1376, 84 p.

Burt, C., and Freeman, B., 2003, Klamath Basin investigation - Hydrologic assessment of the upper Klamath Basin, Issues and opportunities, Draft report, May 2003: San Luis Obispo, California, Irrigation Training and Research Center, California Polytechnic State University, 274 p.

Freeze, R.A., and Cherry, J.A., 1979, Groundwater: Prentice-Hall, Englewood Cliffs, N.J., 604 p.

Gall, I.K., 2011, Technical assistance for the U.S. Bureau of Reclamation water bank in the upper Klamath Basin, 2011: Oregon Water Resources Department Report prepared for the U.S. Bureau of Reclamation under agreement R10AC20099, 17 p., plus tables and appendices.

Gannett, M.W., Lite, K.E., Jr., La Marche, J.L., Fisher, B.J, and Polette, D.J., 2007, Ground-Water Hydrology of the Upper Klamath Basin, Oregon and California: U.S. Geological Survey Scientific Investigations Report 2007-5050, Version 1.1, April 2010, 84 p.

Gannett, M.W., Wagner, B.J., and Lite, K.E., Jr., 2012, Groundwater simulation and management models for the upper Klamath Basin, Oregon and California: U.S. Geological Survey Scientific Investigations Report 2012-5062, 92 p.

Harbaugh, A.W., Banta, E.R., Hill, M.C., and McDonald, M.G., 2000, MODFLOW2000, the U.S. Geological Survey modular ground-water model - User guide to modularization concepts and the Ground-Water Flow Process: U.S. Geological Survey Open-File Report 00-92, 121p.

Hill, M.C., 1990, PRECONDITIONED CONJUGATE-GRADIENT 2 (PCG2), a computer program for solving ground-water flow equations: U.S. Geological Survey Water-Resources Investigations Report 90-4048, 43 p.

Hill, M.C., 1998, Methods and guidelines for effective model calibration: U.S. Geological Survey Water-Resources Investigations Report 98-4005, 90 p. 
Hill, M.C., Banta, E.R., Harbaugh, A.W., and Anderman, E.R., 2000, MODFLOW-2000, The U.S. Geological Survey modular ground-water model - User guide to the observation, sensitivity, and parameter-estimation processes and three postprocessing programs: U.S. Geological Survey Open-File Report 00-184, 209 p.

Hill, M.C., and Tiedeman, C.R., 2007, Effective groundwater model calibration, with analysis of sensitivities, predictions, and uncertainty: New York, Wiley, $455 \mathrm{p}$.

Klamath Basin Restoration Agreement (KBRA), 2010, Klamath Basin restoration agreement for the sustainability of public and trust resources and affected communities - February 18, 2010: Klamath Basin Restoration Agreement, 378 p., accessed January 17, 2012 at http://klamathrestoration.gov/.

La Rue, E.C., 1922, Klamath River and its utilization: Report to the Office of the State Engineer, Salem, Oregon, 204 p.

McDonald, M.G., and Harbaugh, A.W., 1988, A modular three-dimensional finitedifference ground-water flow model: U.S. Geological Survey Techniques of Water-Resources Investigations, book 6, chap. A1, 586 p.

National Research Council, 2004, Endangered and Threatened Fishes in the Klamath River Basin, 384 p.

Palmer, P.C., Gannett, M.W., Hinkle, S.R., 2006, Isotopic characterization of three groundwater recharge sources and inferences for selected aquifers in the upper Klamath Basin of Oregon and California, USA, Journal of Hydrology, vol. 336, $13 \mathrm{p}$.

Reilly, T.E., Dennehy, K.F., Alley, W.M., and Cunningham, W.L., 2008, Ground-water availability in the United States: U.S. Geological Survey Circular 1323, 70 p.

Risley, J.C., and Gannett, M.W., 2006, An evaluation and review of water-use estimates and flow data for the Lower Klamath and Tule Lake National Wildlife Refuges, Oregon and California: U.S. Geological Survey Scientific Investigations Report 2006-5036, $18 \mathrm{p}$.

Theis, C.V., 1940, The source of water derived from wells - Essential factors controlling the response of an aquifer to development: Civil Engineering, v. 10, no. 5, p. 277280.

Wagner, B.J., and Gannett, M.W., 2014, Evaluation of alternative groundwatermanagement strategies for the upper Klamath Basin, Oregon and California: U.S. Geological Survey Scientific Investigations Report 2014-5054, 48p. 
Appendix A: Simulated and Observed Hydraulic Head for All Observation Wells 


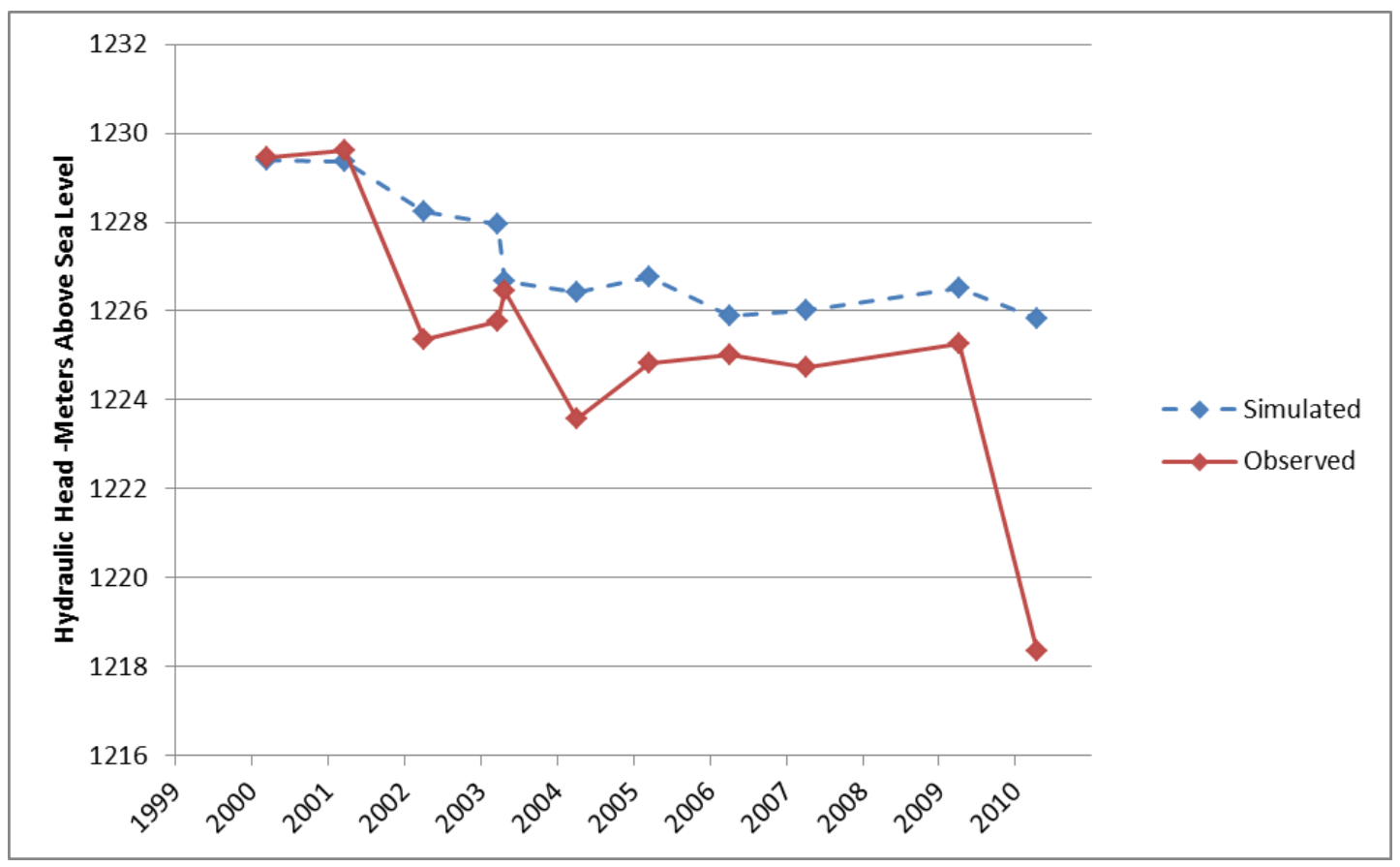

Figure 25. Observed and simulated water-level elevations in well 41.00S/12.00E-15CBB01 (Observation Well 1)

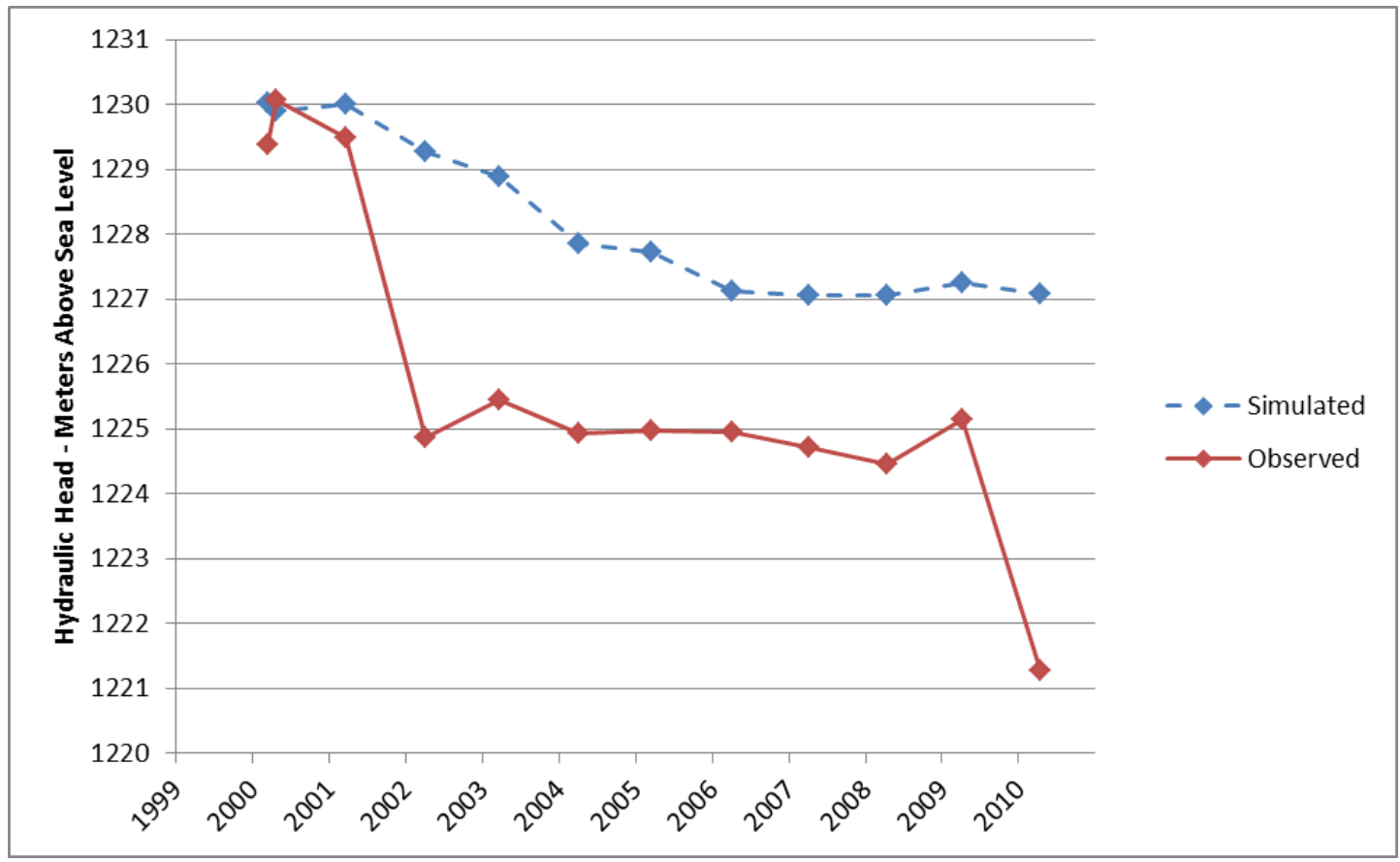

Figure 26. Observed and simulated water-level elevations in well 41.00S/12.00E-10CCC01 (Observation Well 2) 


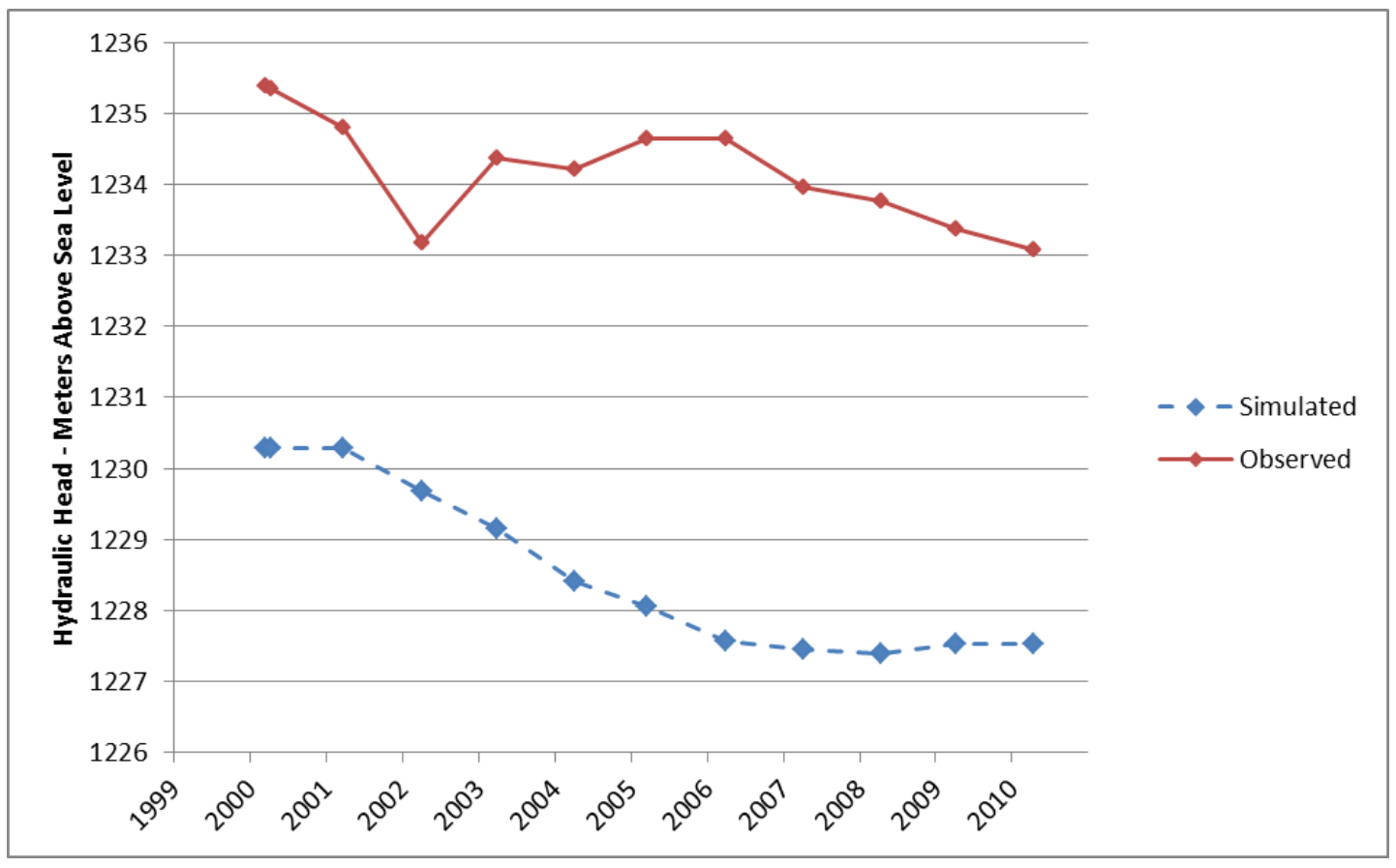

Figure 27. Observed and simulated water-level elevations in well 41.00S/12.00E-09CAD01 (Observation Well 3)

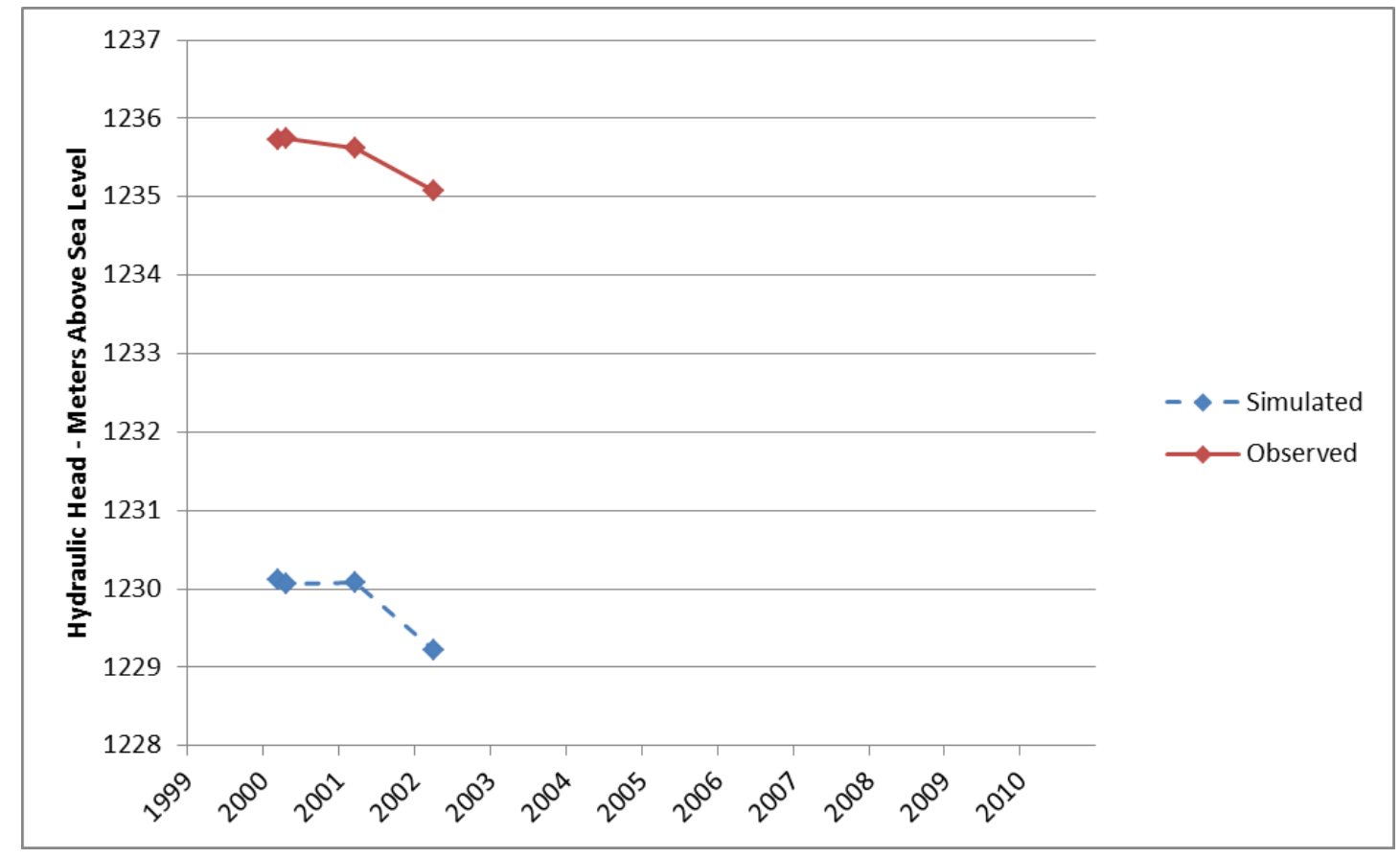

Figure 28. Observed and simulated water-level elevations in well 41.00S/12.00E-08DBD01 (Observation Well 4) 


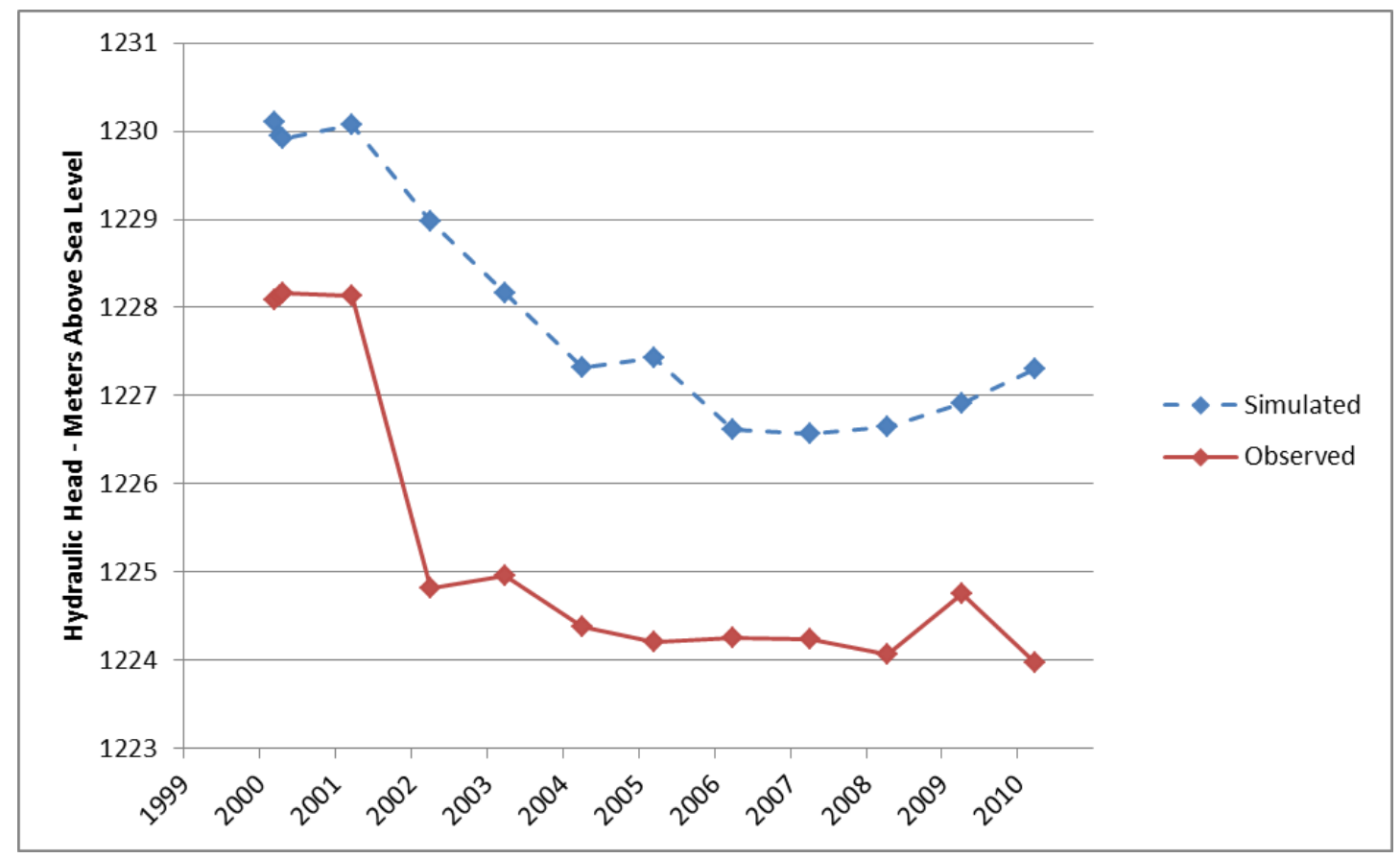

Figure 29. Observed and simulated water-level elevations for well 41.00S/12.00E-09BAD01 (Observation Well 6)

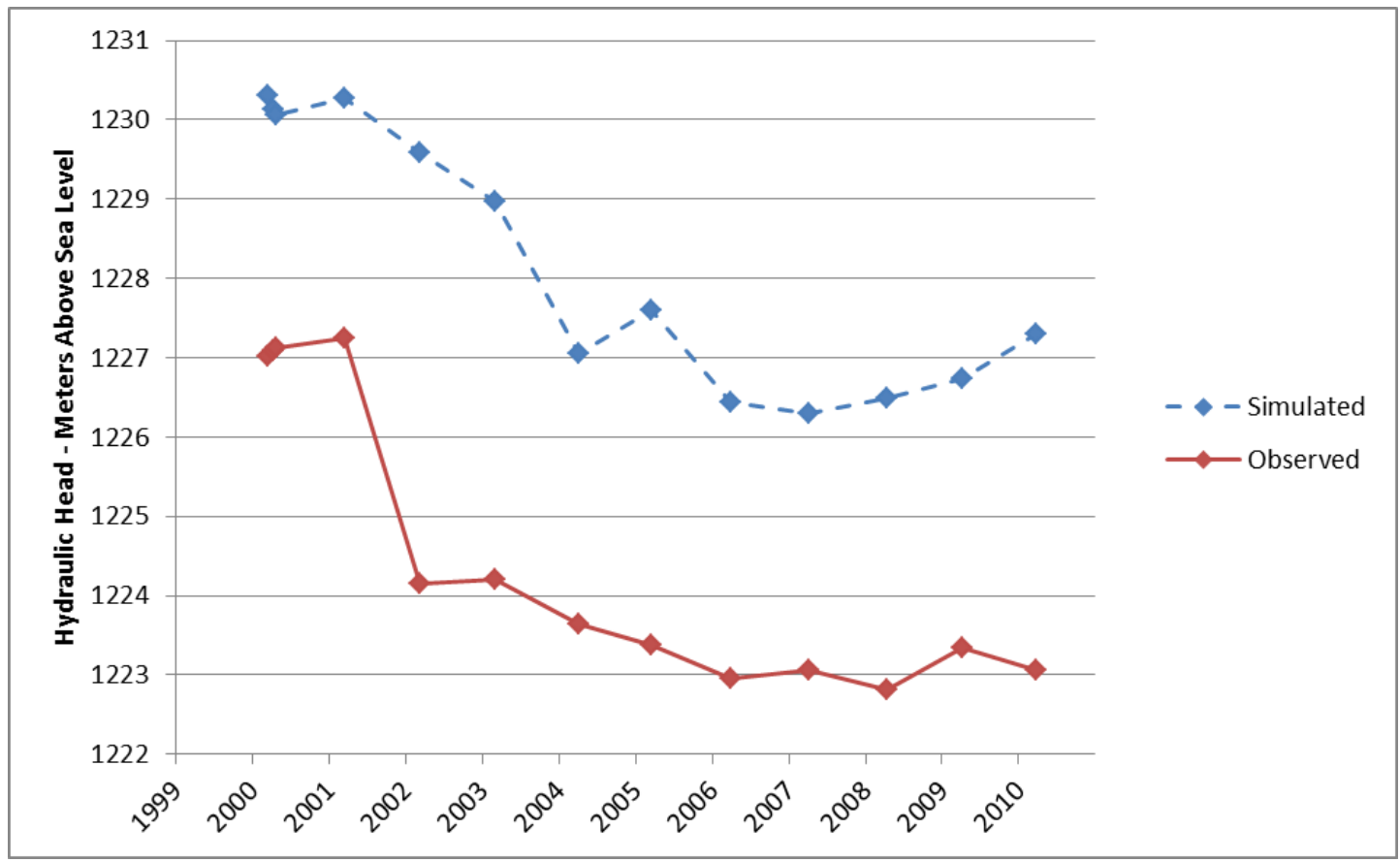

Figure 30. Observed and simulated water-level elevations in well 41.00S/12.00E-04CBC01 (Observation Well 8) 


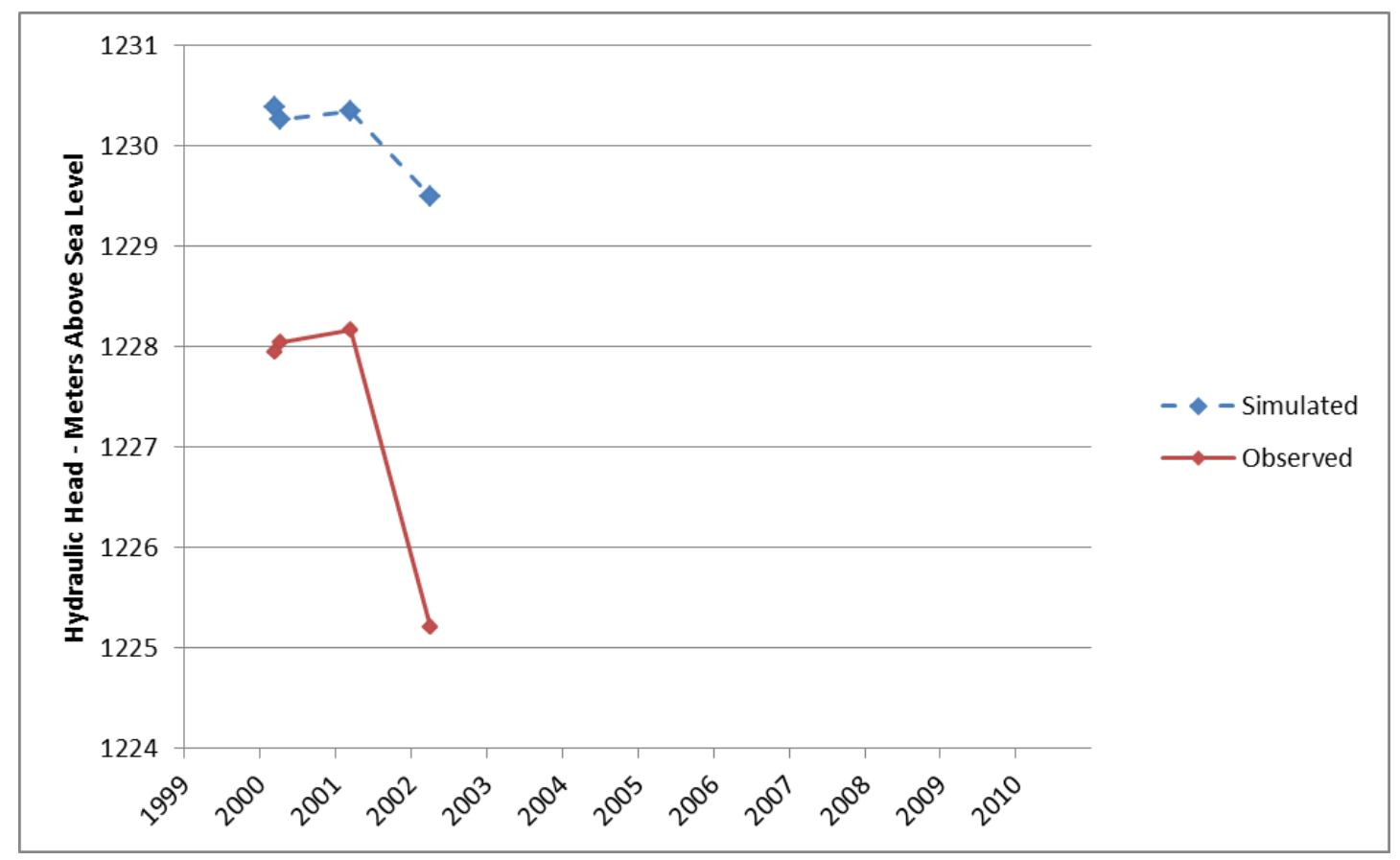

Figure 31. Observed and simulated water-level elevations in well 41.00S/12.00E-04CBB01 (Observation Well 10)

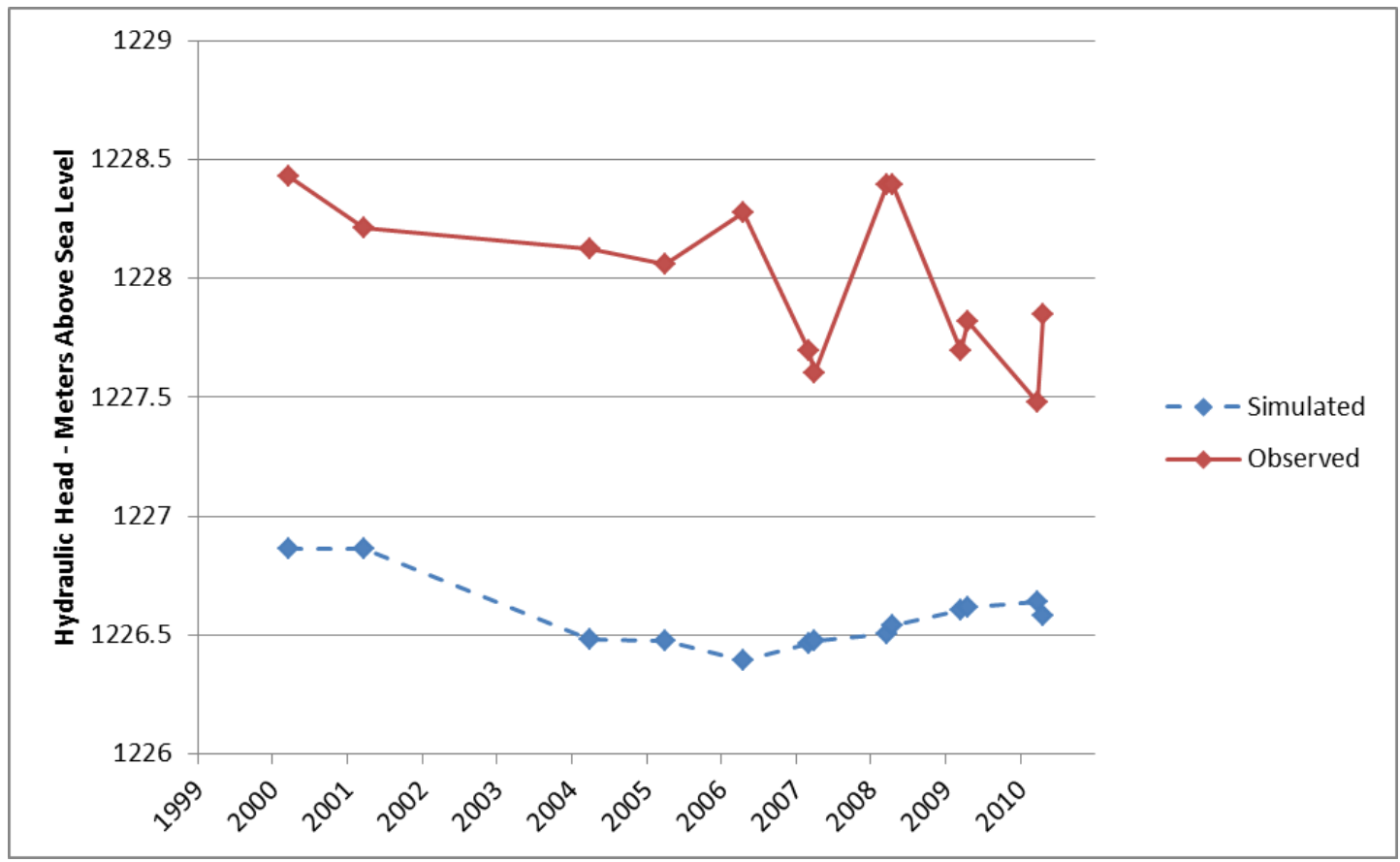

Figure 32. Observed and simulated water-level elevations in CDWR well 46N05E01P001M (Observation Well 13) 


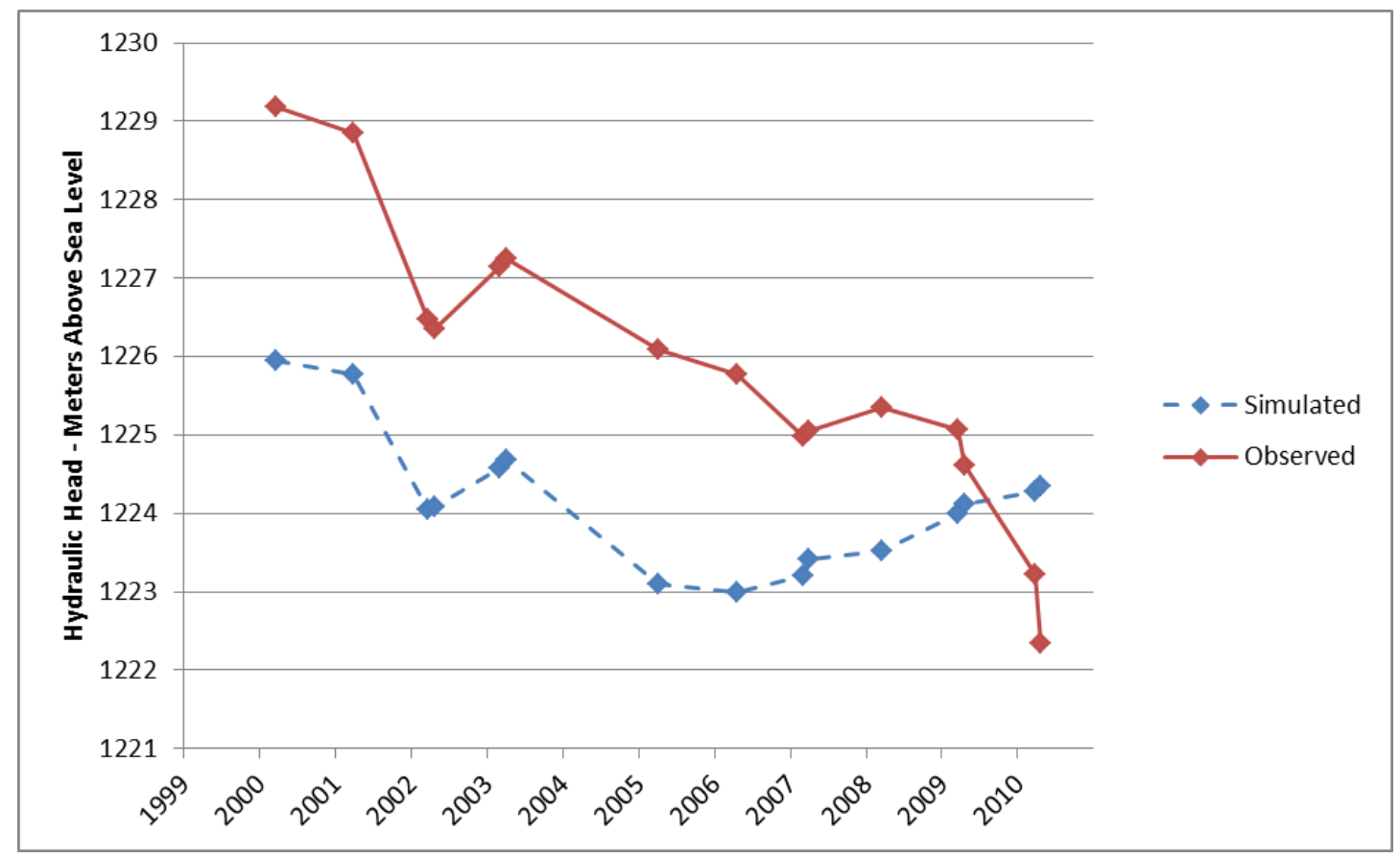

Figure 33. Observed and simulated water-level elevations in CDWR well 46N05E03M001M (Observation Well 14)

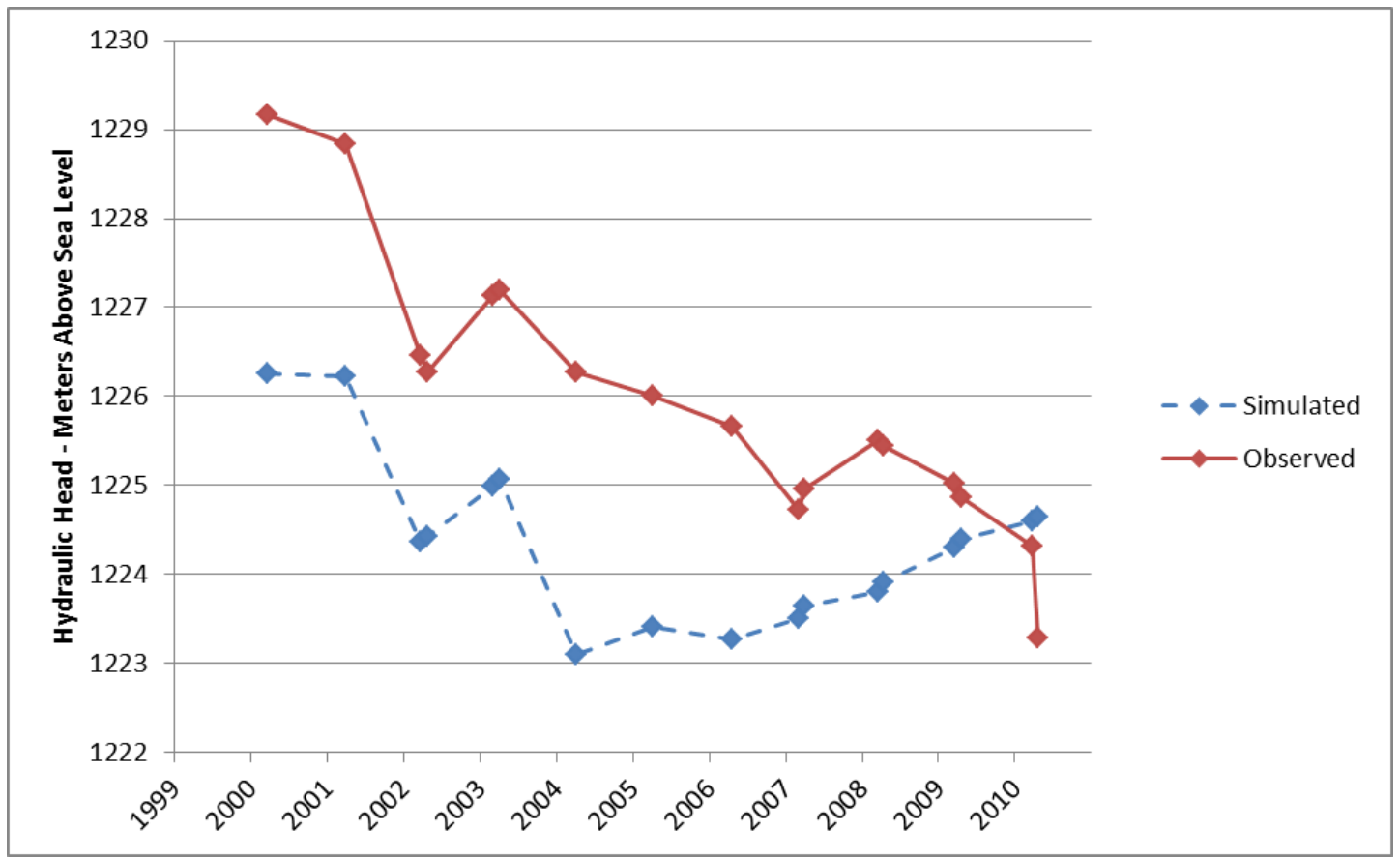

Figure 34. Observed and simulated water-level elevations for CDWR well 46N05E03P001M (Observation Well 15) 


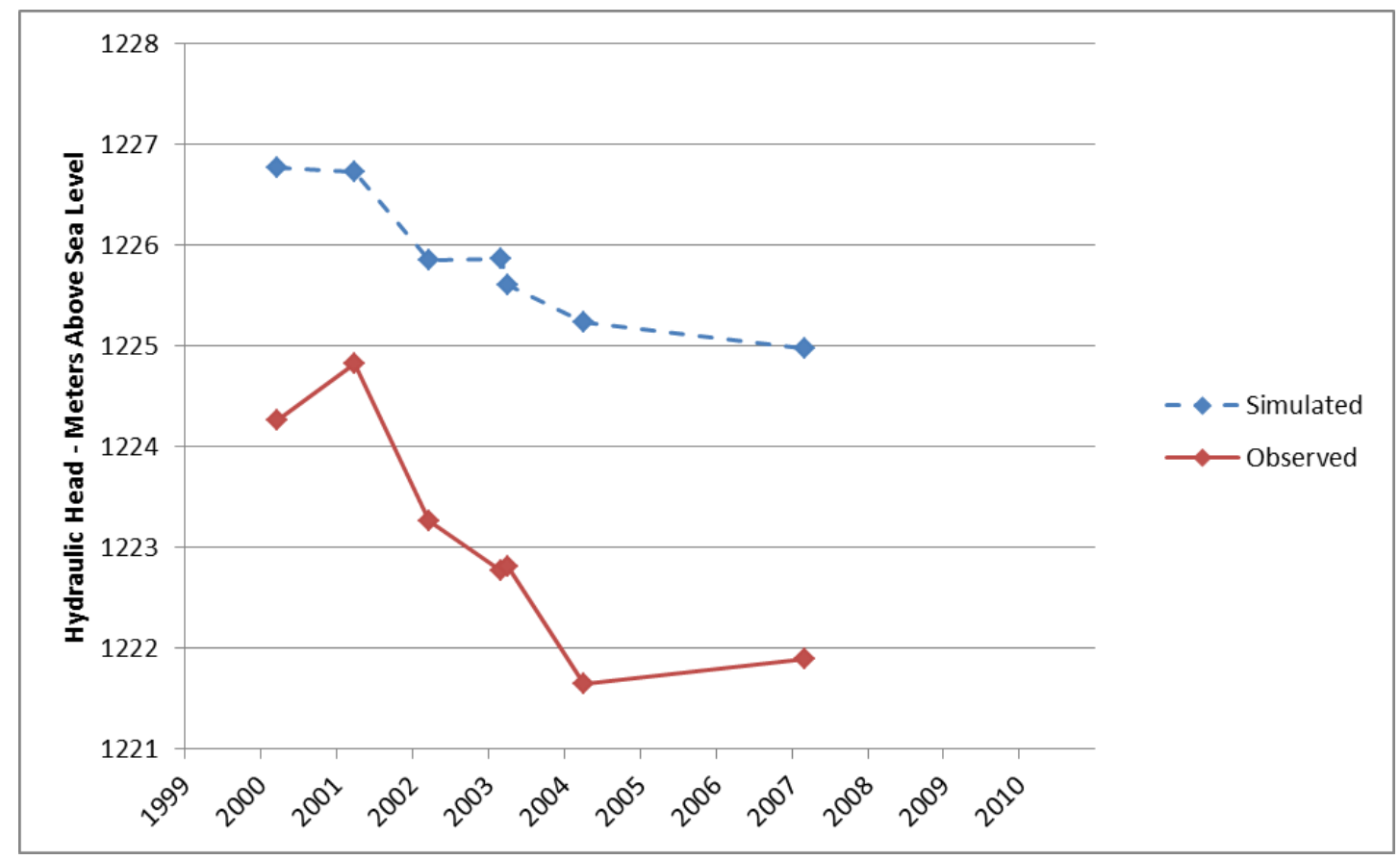

Figure 35. Observed and simulated water-level elevations in CDWR well 46N05E09J002M (Observation Well 16)

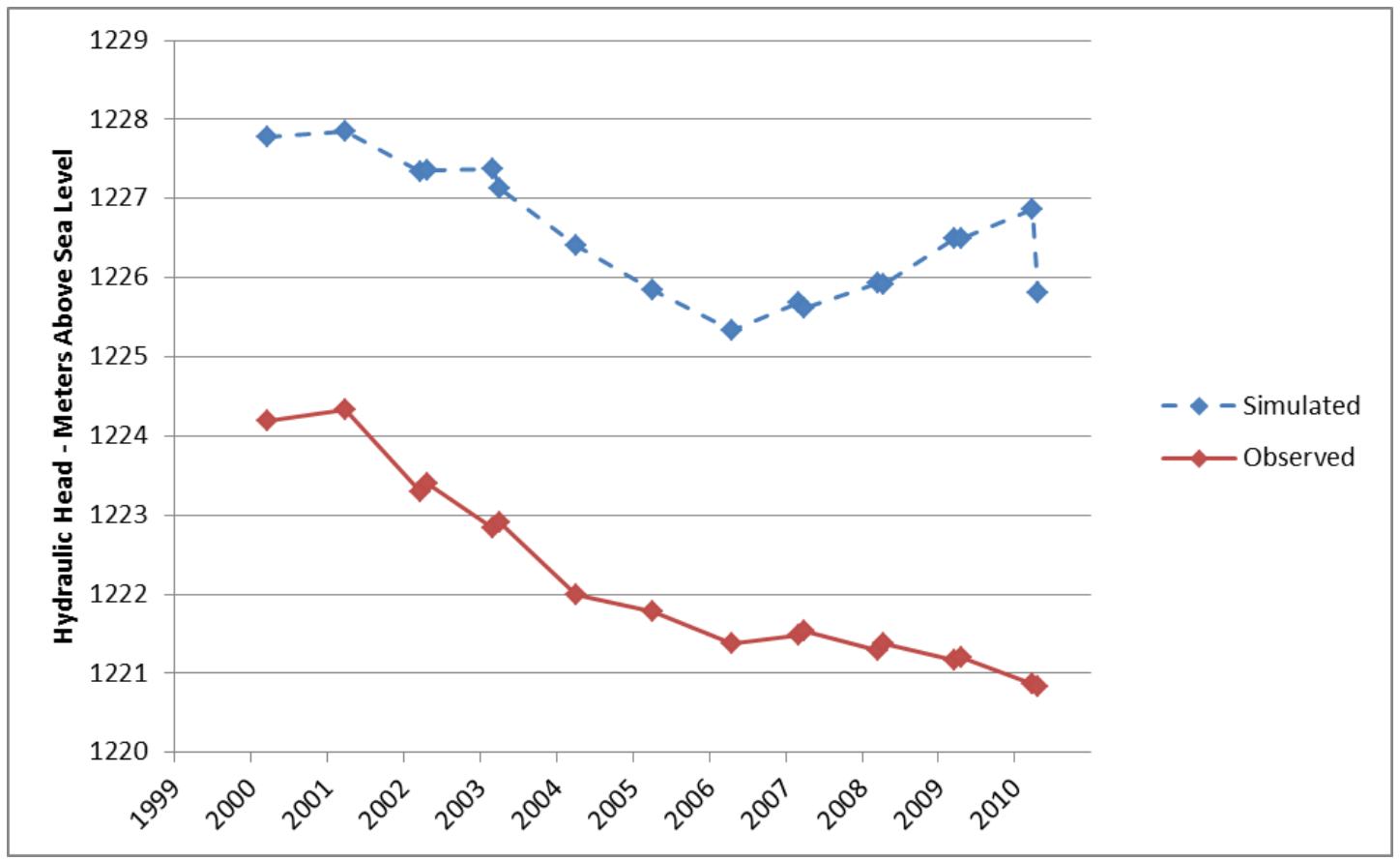

Figure 36. Observed and simulated water-level elevations in CDWR well 46N05E23G002M (Observation Well 17) 


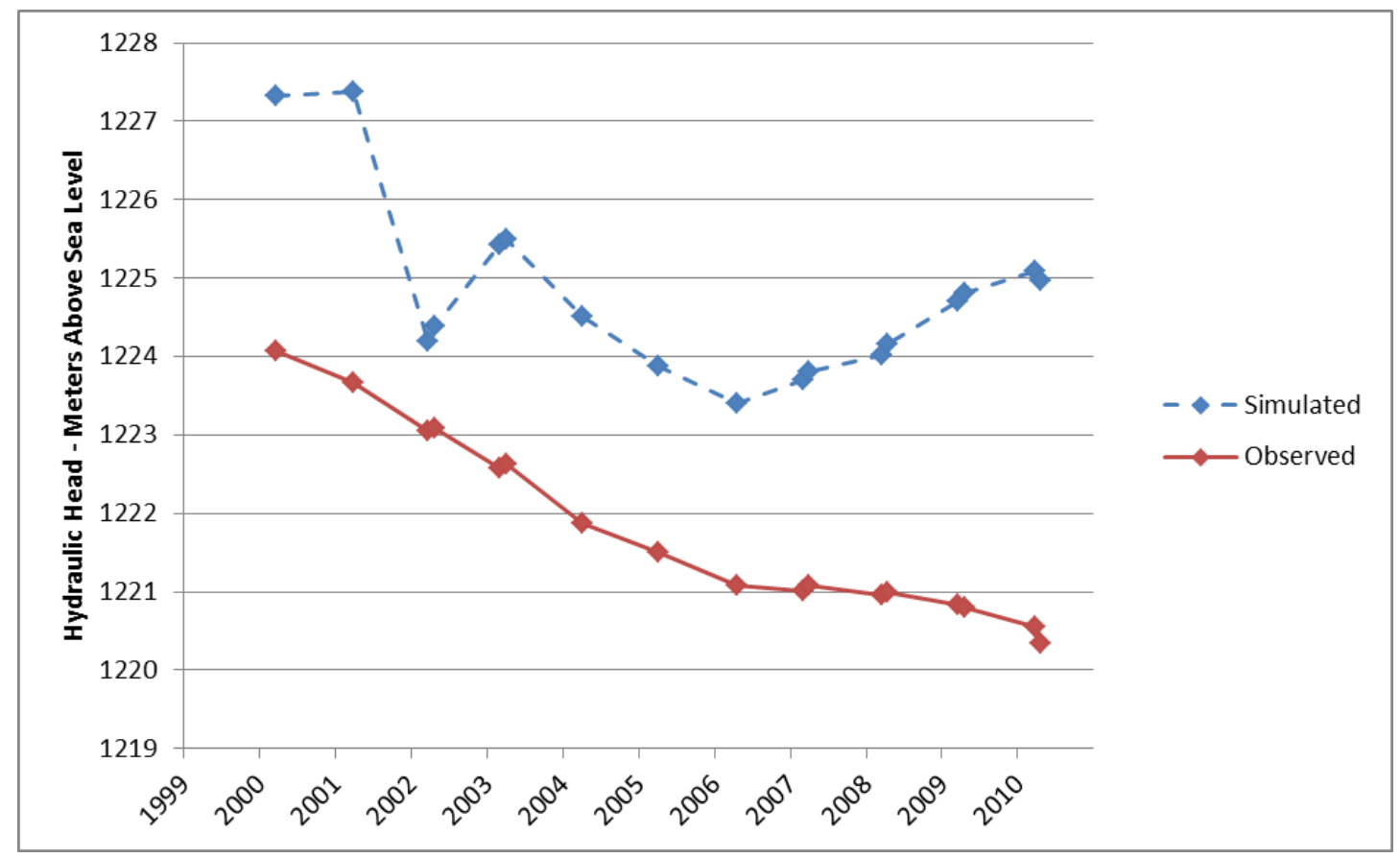

Figure 37. Observed and simulated water-level elevations in CDWR well 46N06E07K002M (Observation Well 18)

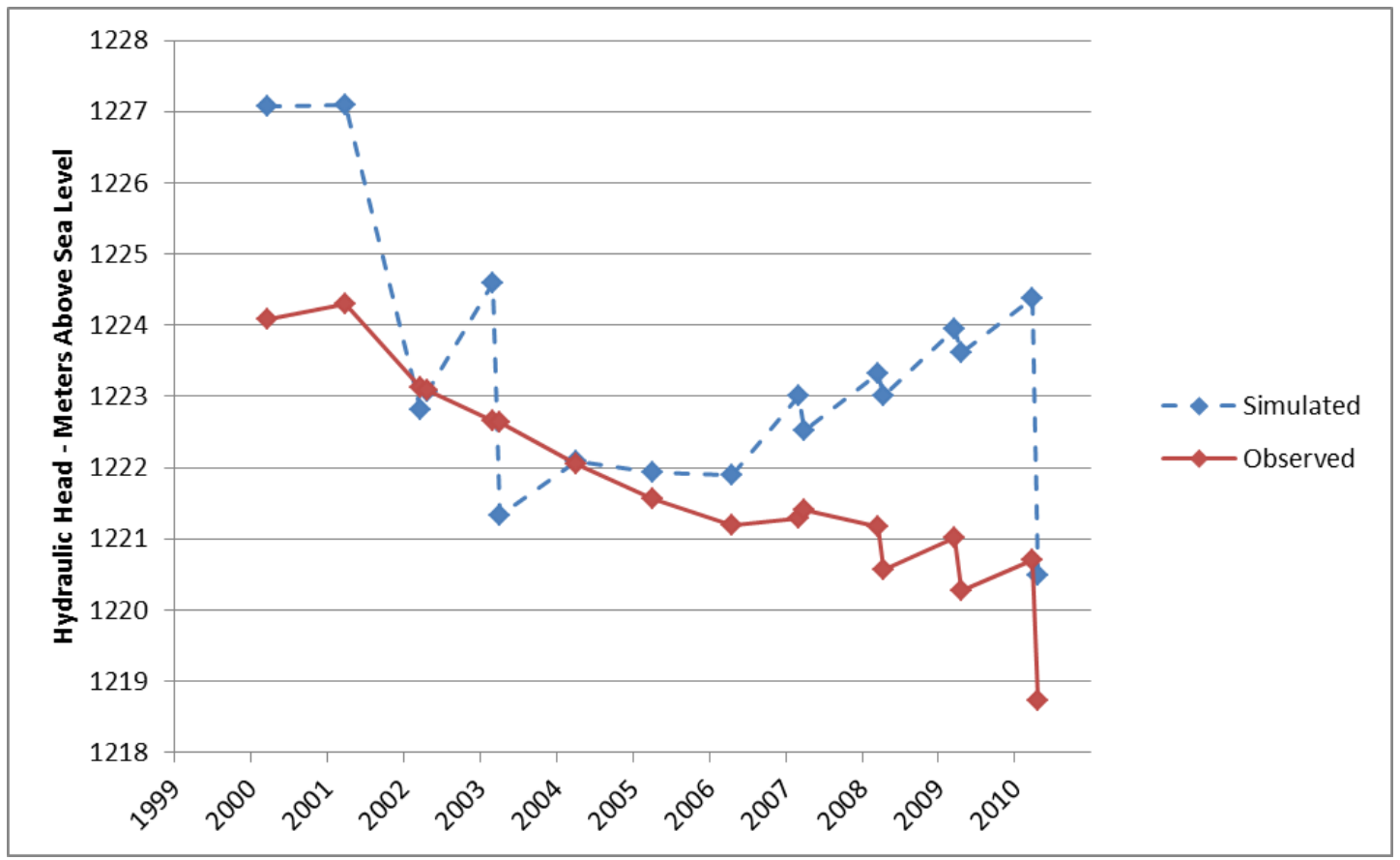

Figure 38. Observed and simulated water-level elevations in CDWR well 46N06E08E001M (Observation Well 19) 


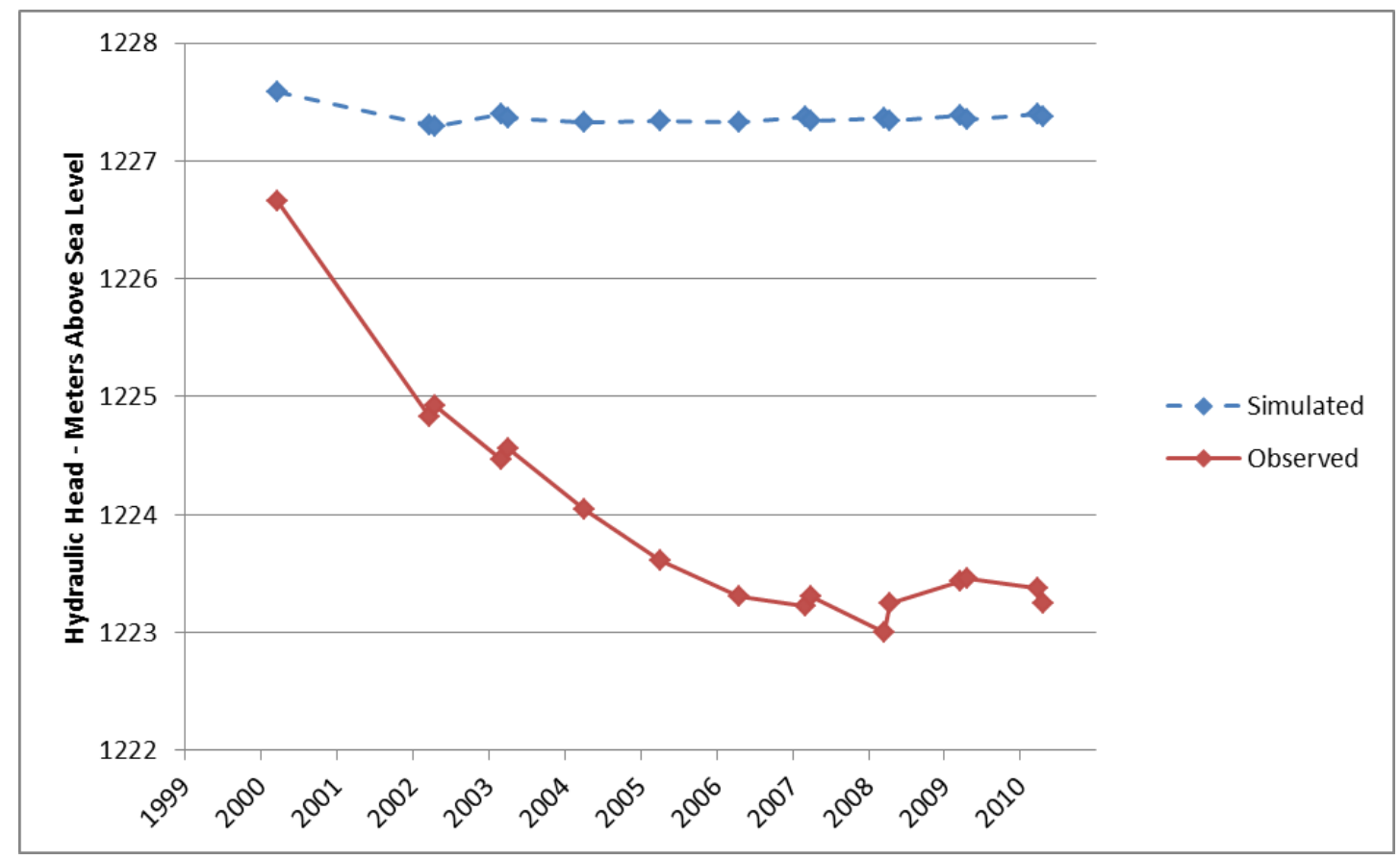

Figure 39. Observed and simulated water-level elevations in CDWR well 47N04E07Q001M (Observation Well 20)

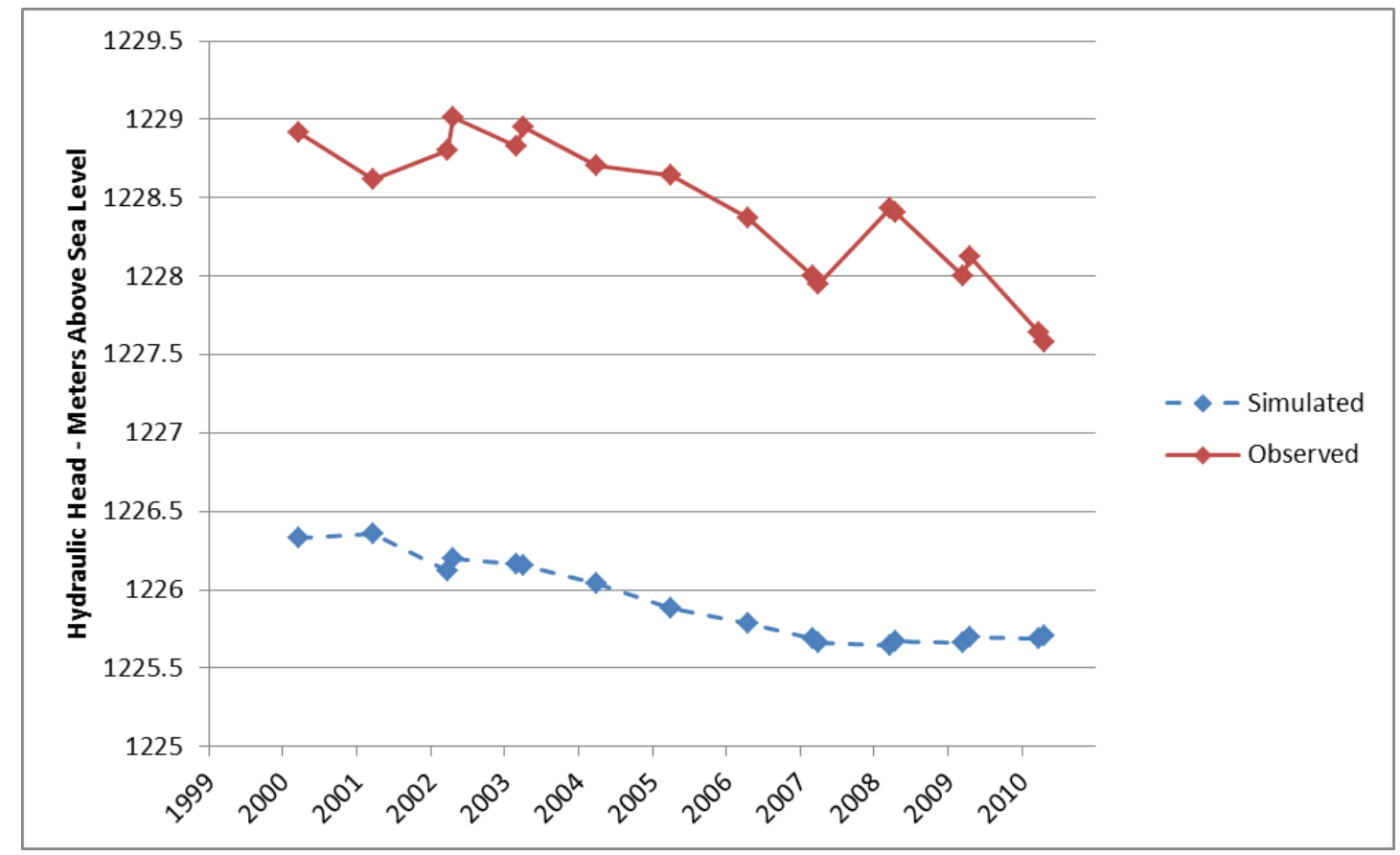

Figure 40. Observed and simulated water-level elevations in CDWR well 47N05E01N001M (Observation Well 21) 


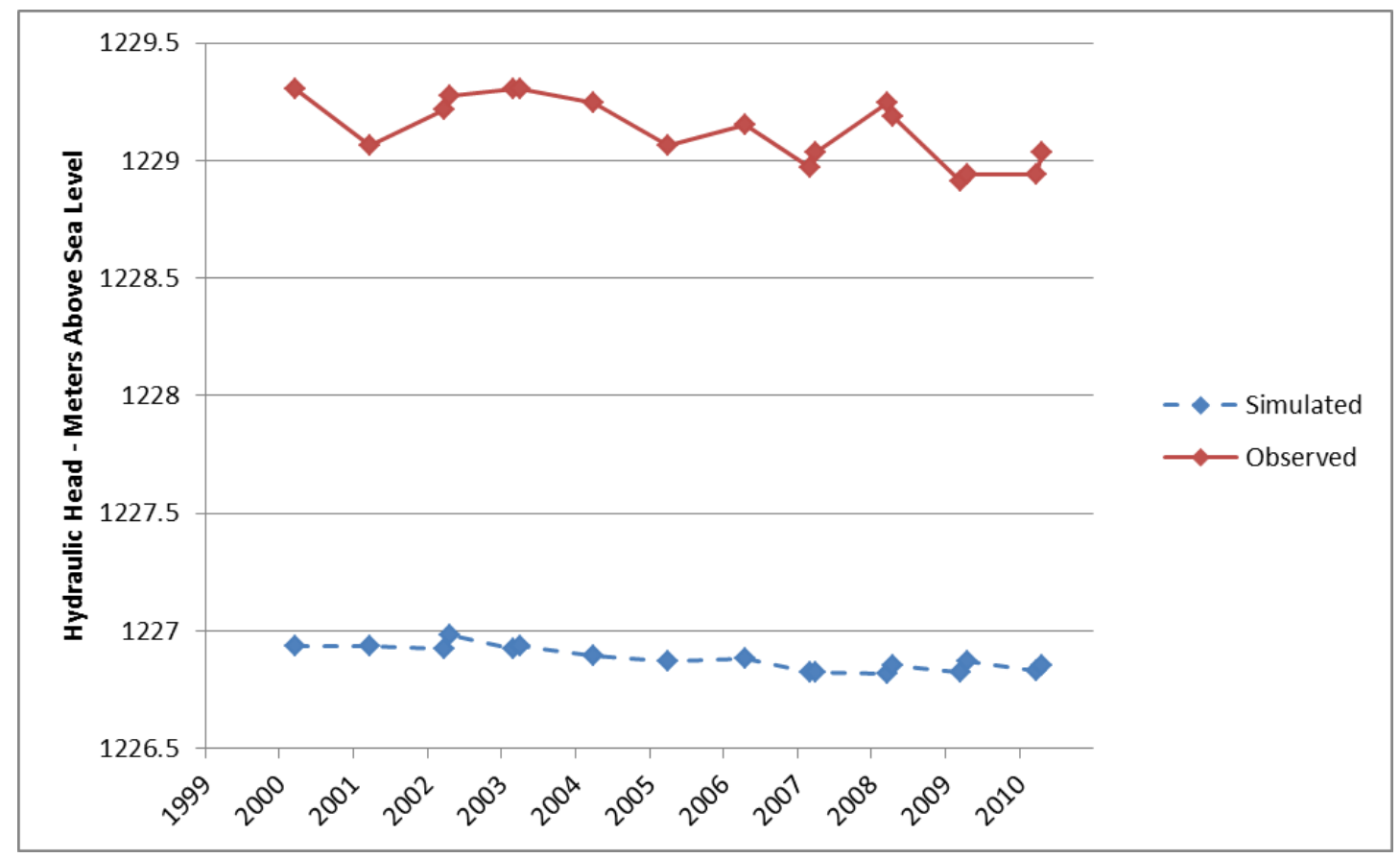

Figure 41. Observed and simulated water-level elevations in CDWR well 47N05E04M001M (Observation Well 22)

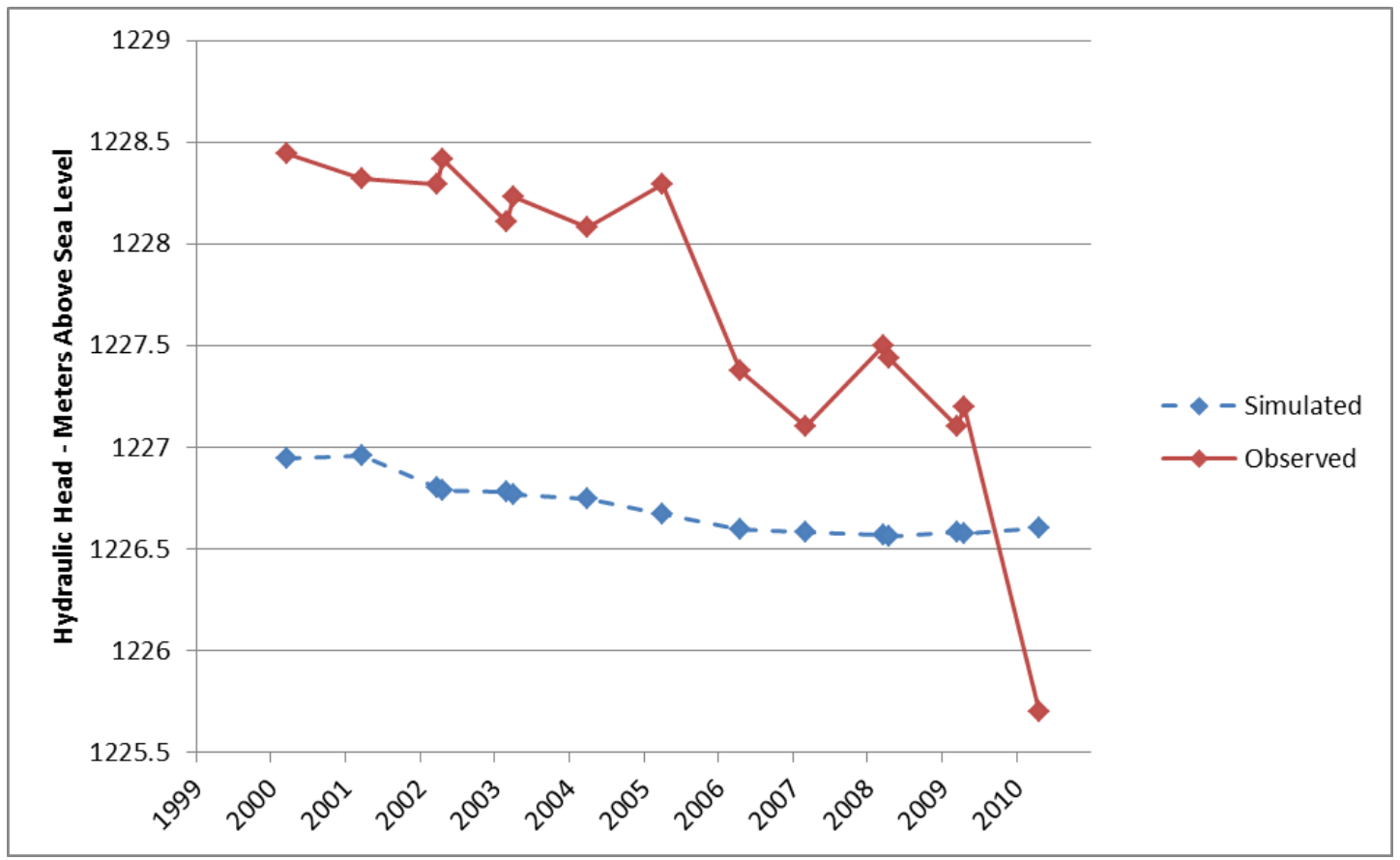

Figure 42. Observed and simulated water-level elevations in CDWR well 47N05E26F001M (Observation Well 23) 


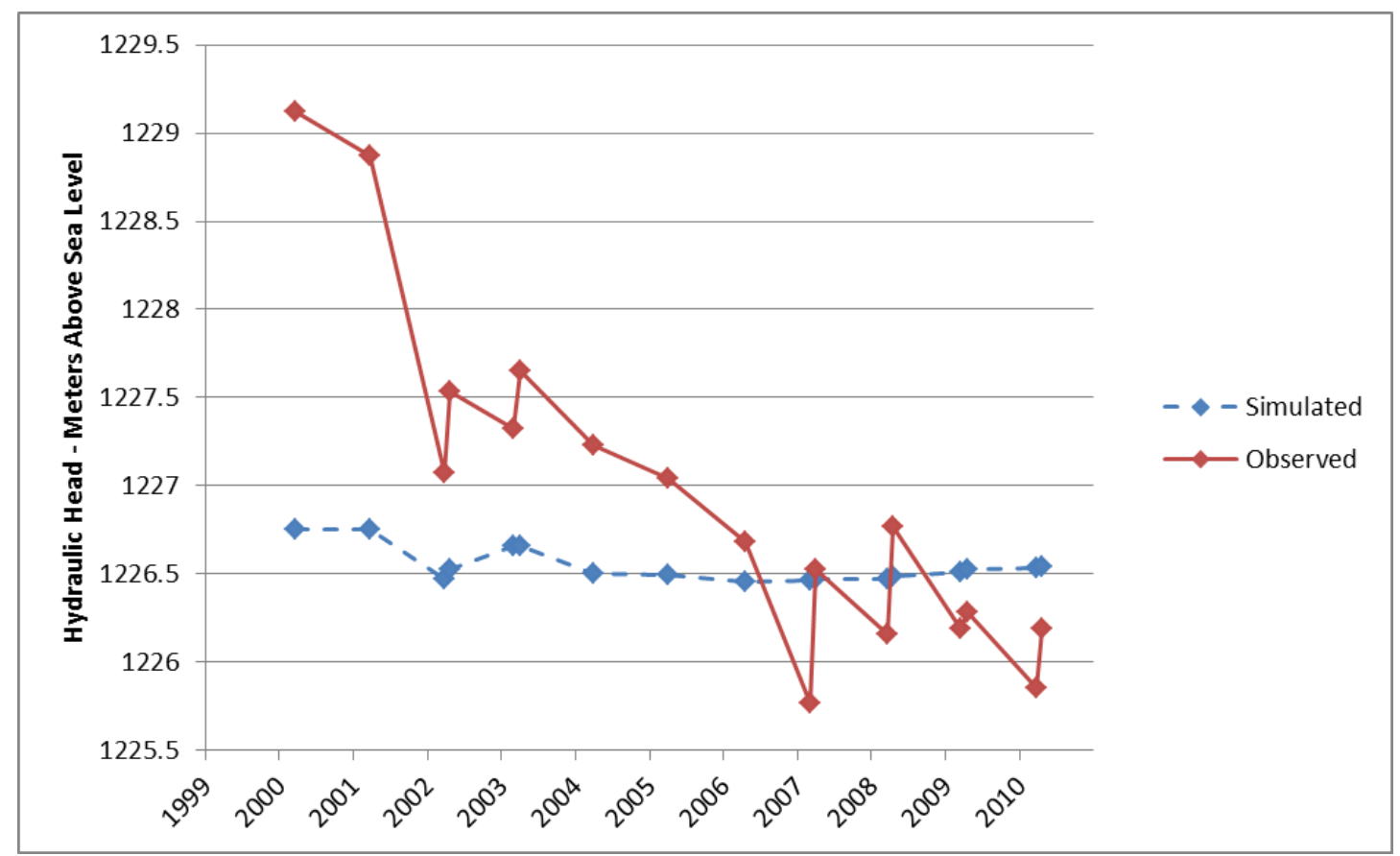

Figure 43. Observed and simulated water-level elevations in CDWR well 47N05E33F001M (Observation Well 24)

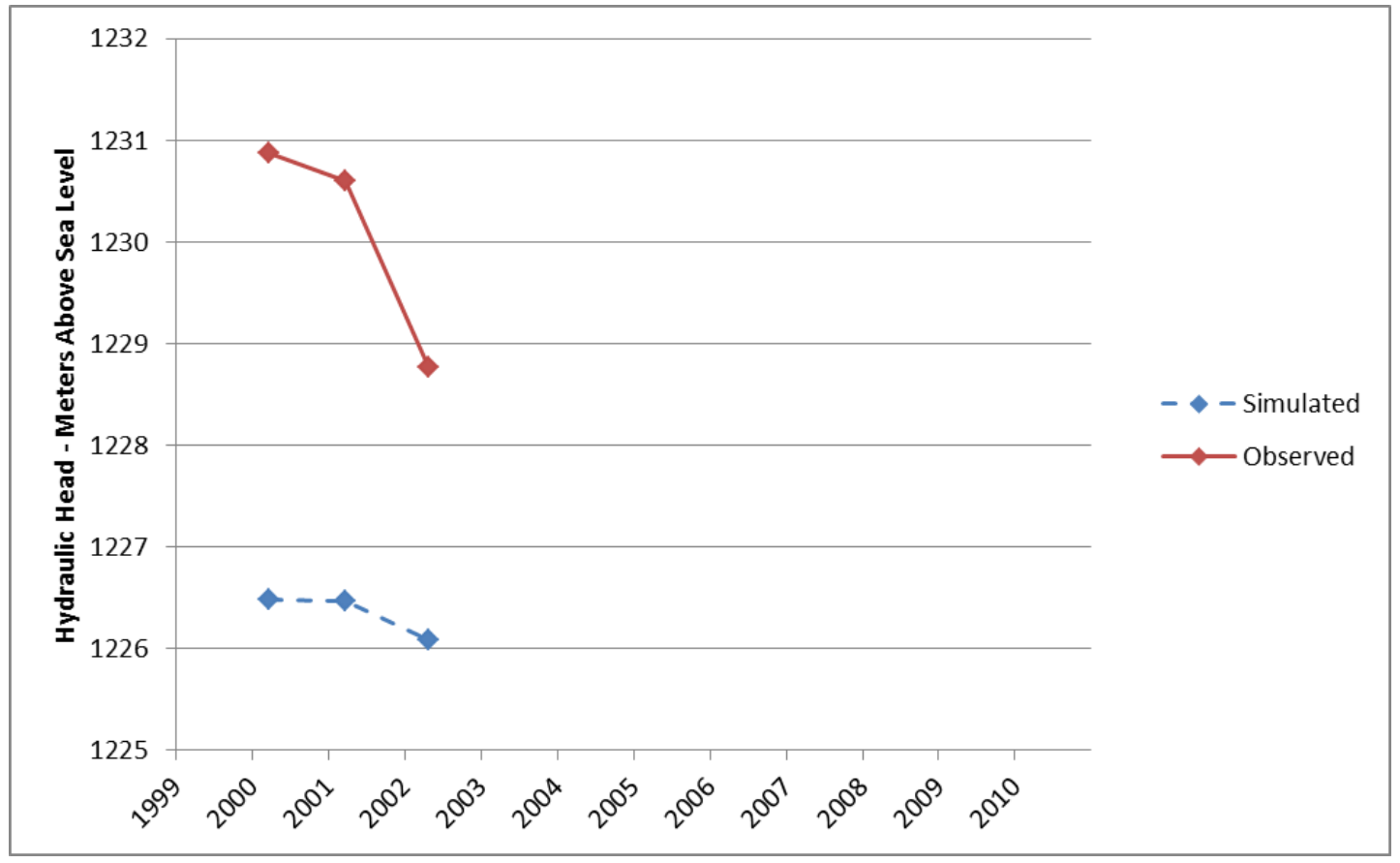

Figure 44. Observed and simulated water-level elevations in CDWR well 47N05E33J001M (Observation Well 25) 


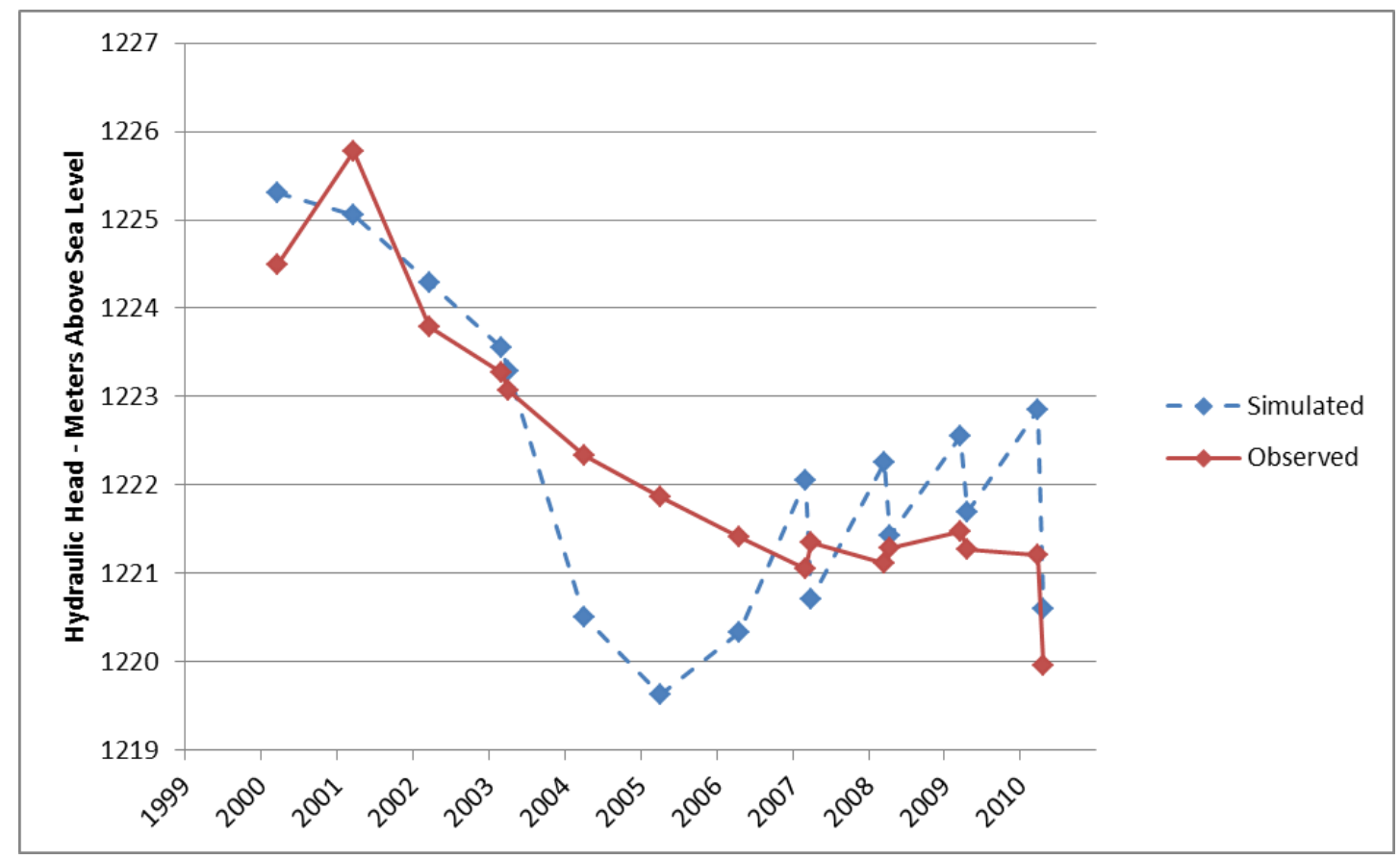

Figure 45. Observed and simulated water-level elevations in CDWR well 47N06E06N002M (Observation Well 26)

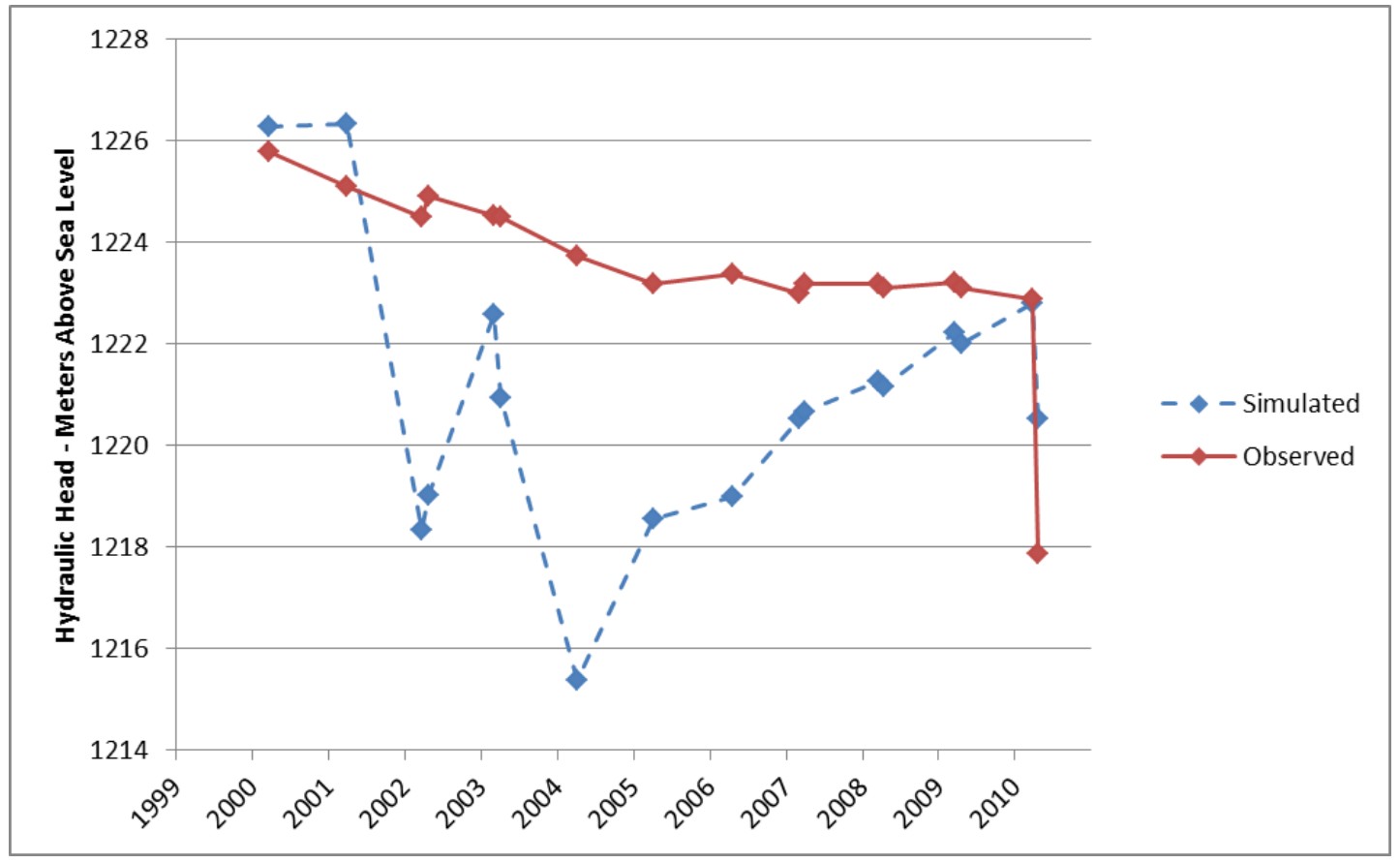

Figure 46. Observed and simulated water-level elevations in CDWR well 47N06E19D002M (Observation Well 27) 


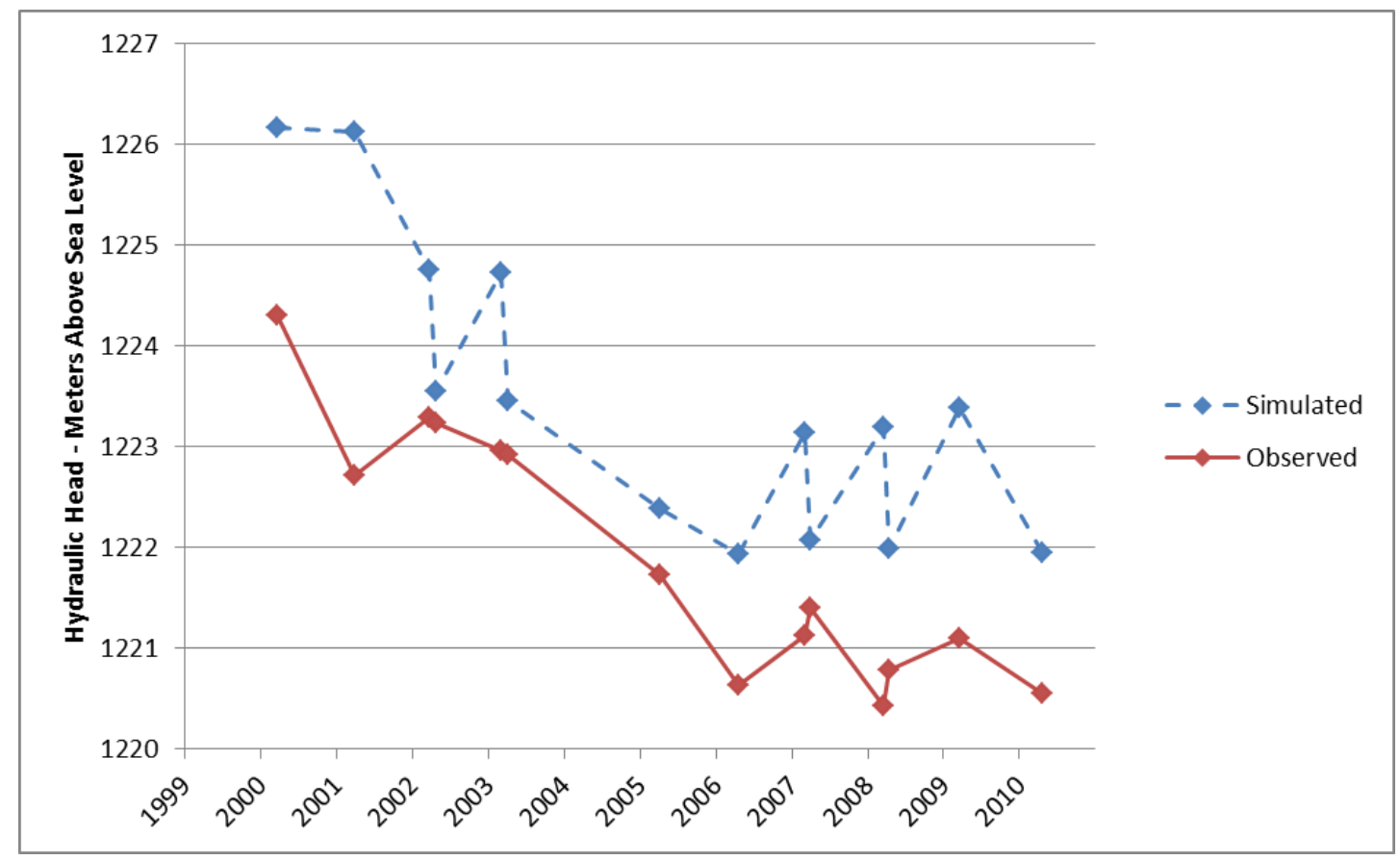

Figure 47. Observed and simulated water-level elevations in CDWR well 47N06E30H001M (Observation Well 28)

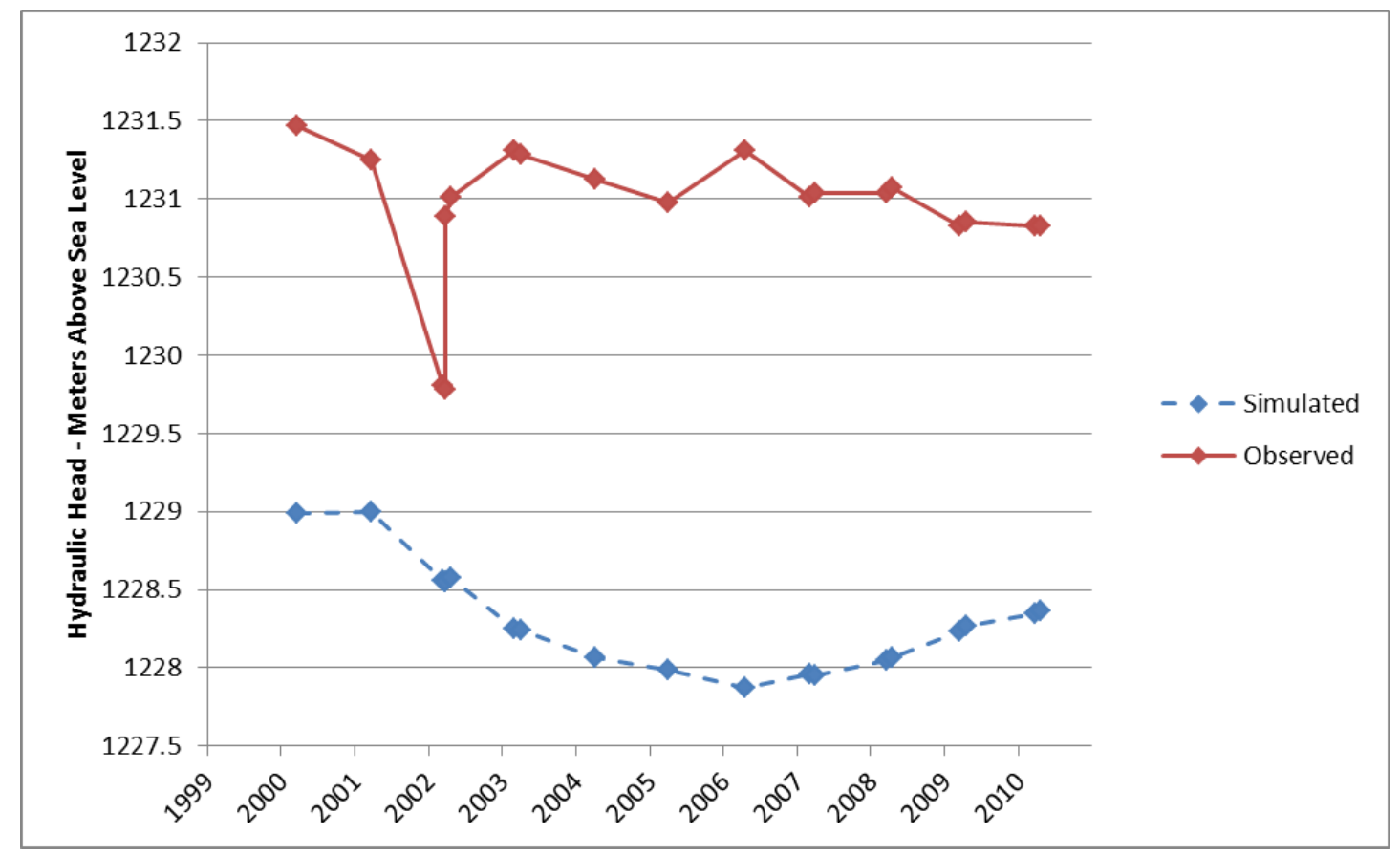

Figure 48. Observed and simulated water-level elevations in CDWR well 48N04E14M001M (Observation Well 29) 


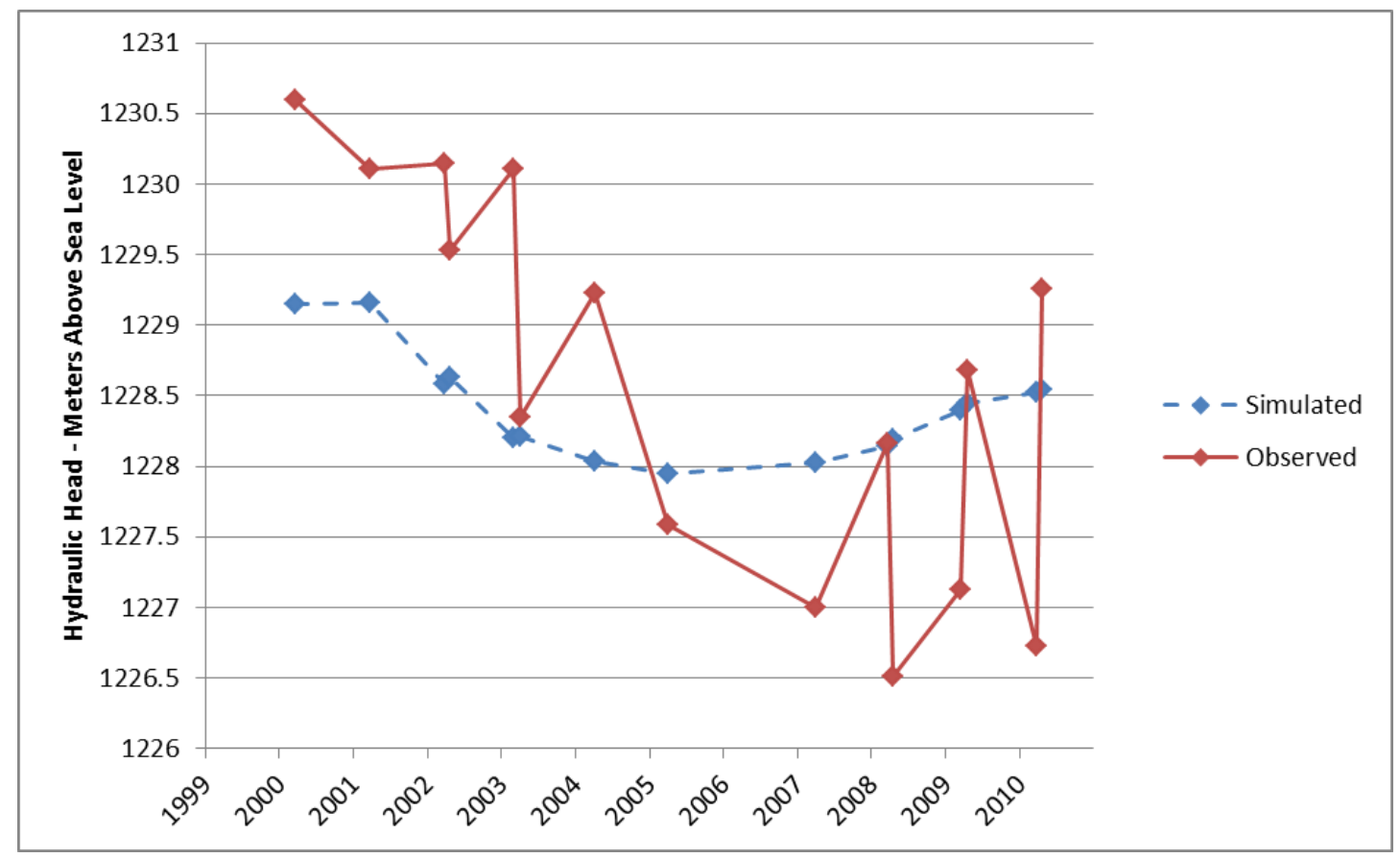

Figure 49. Observed and simulated water-level elevations for CDWR well 48N04E16L002M (Observation Well 30)

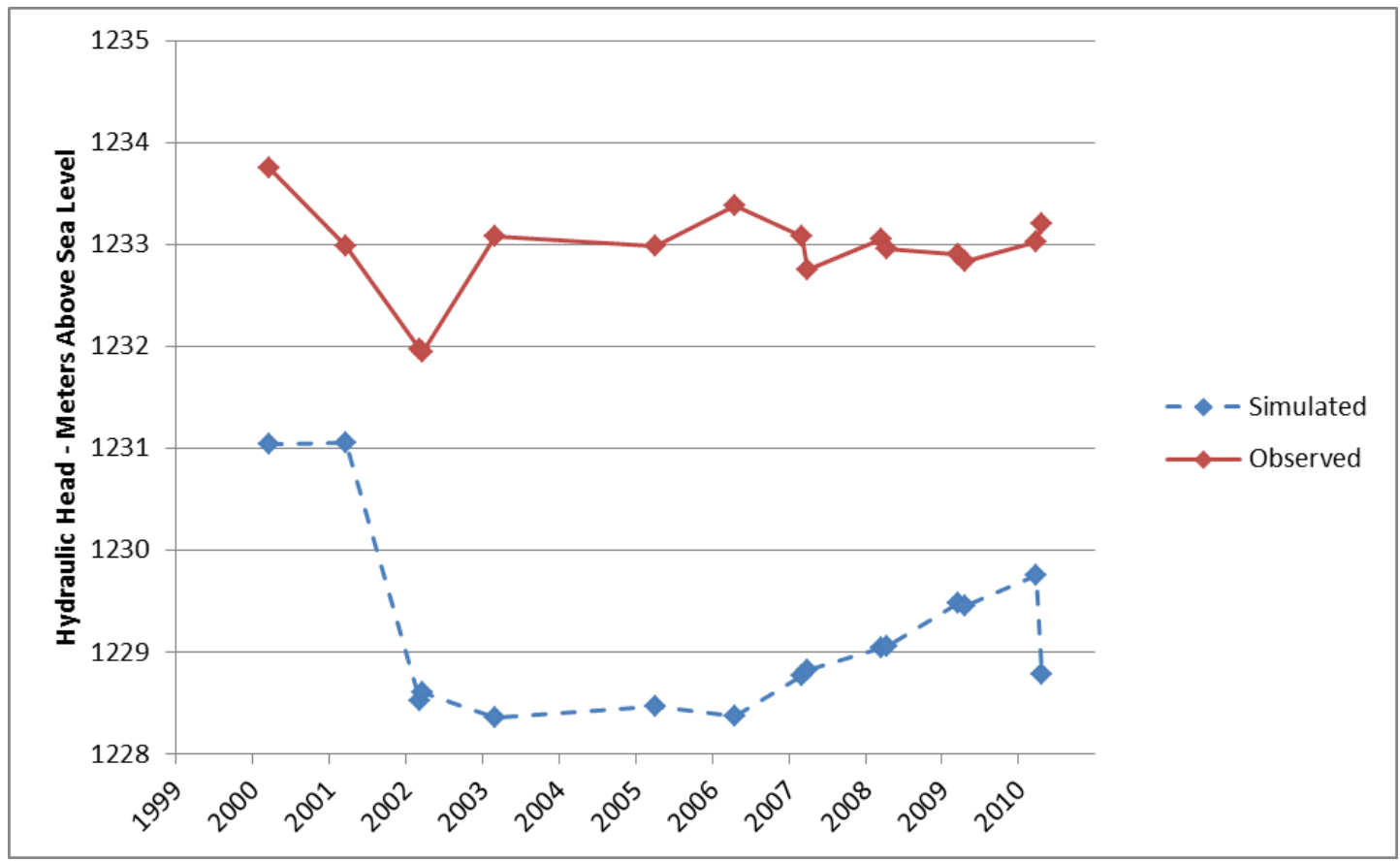

Figure 50. Observed and simulated water-level elevations for CDWR well 48N04E18L003M (Observation Well 31) 


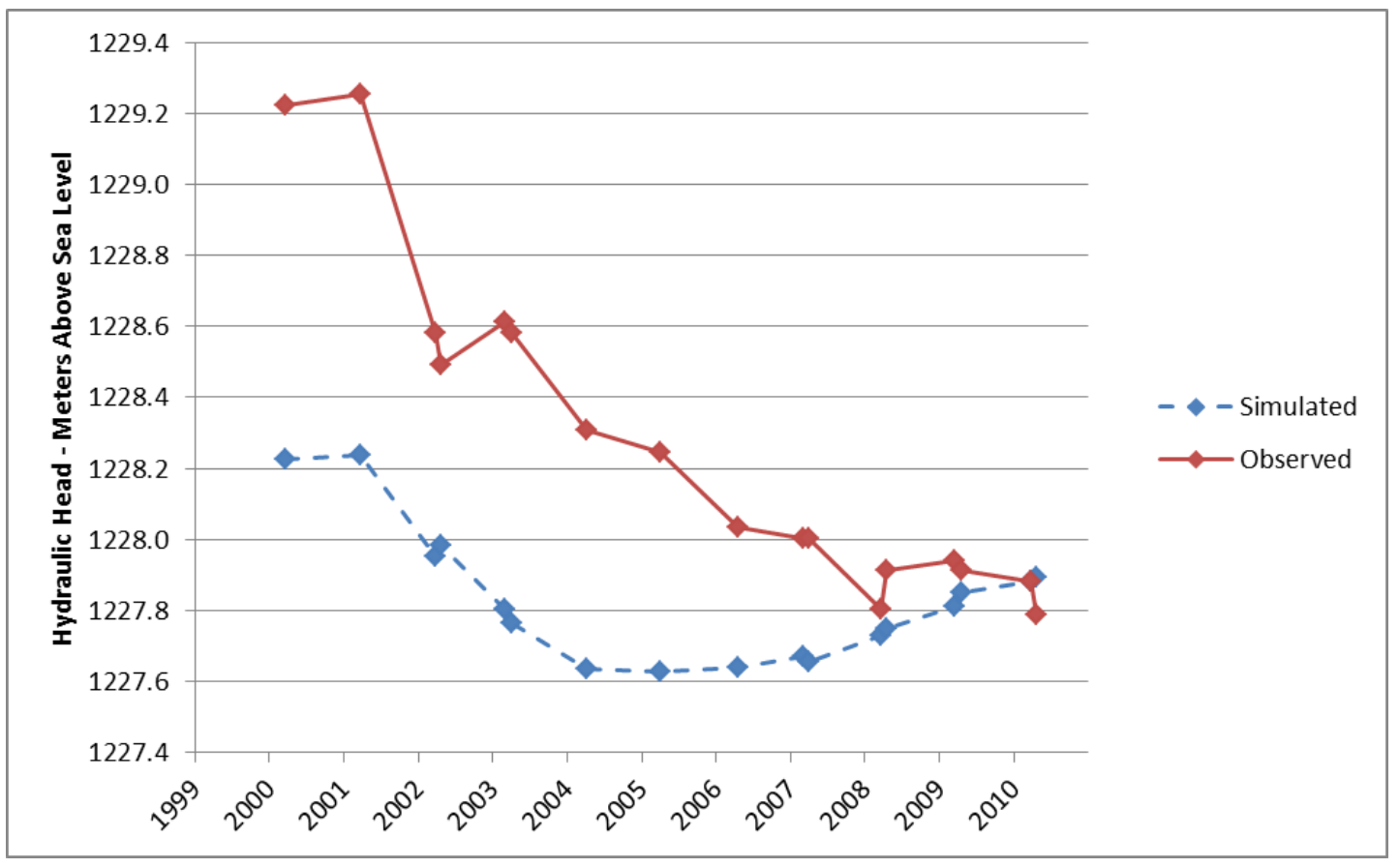

Figure 51. Observed and simulated water-level elevations in CDWR well 48N04E28D001M (Observation Well 32)

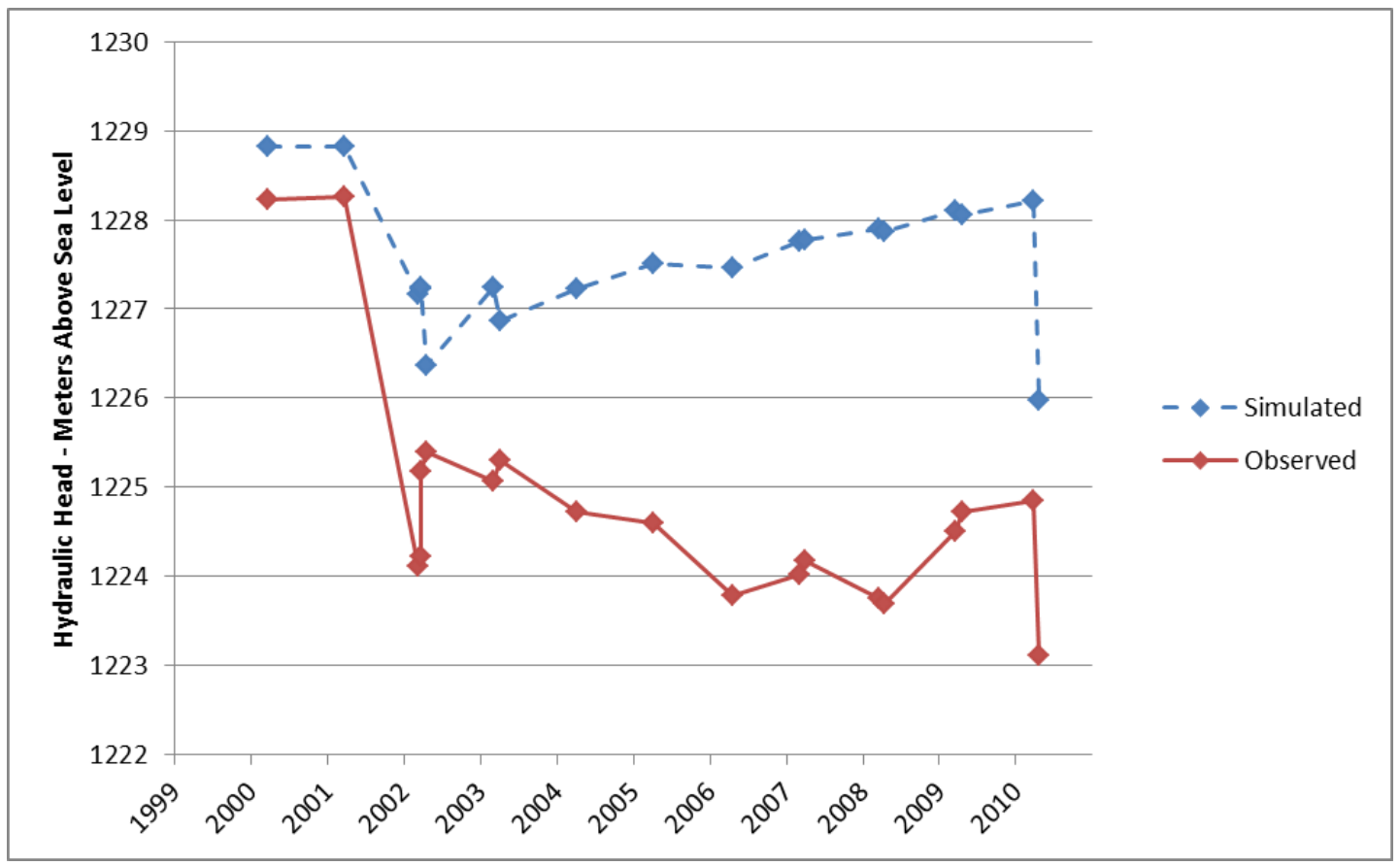

Figure 52. Observed and simulated water-level elevations in CDWR well 48N04E30F001M (Observation Well 33) 


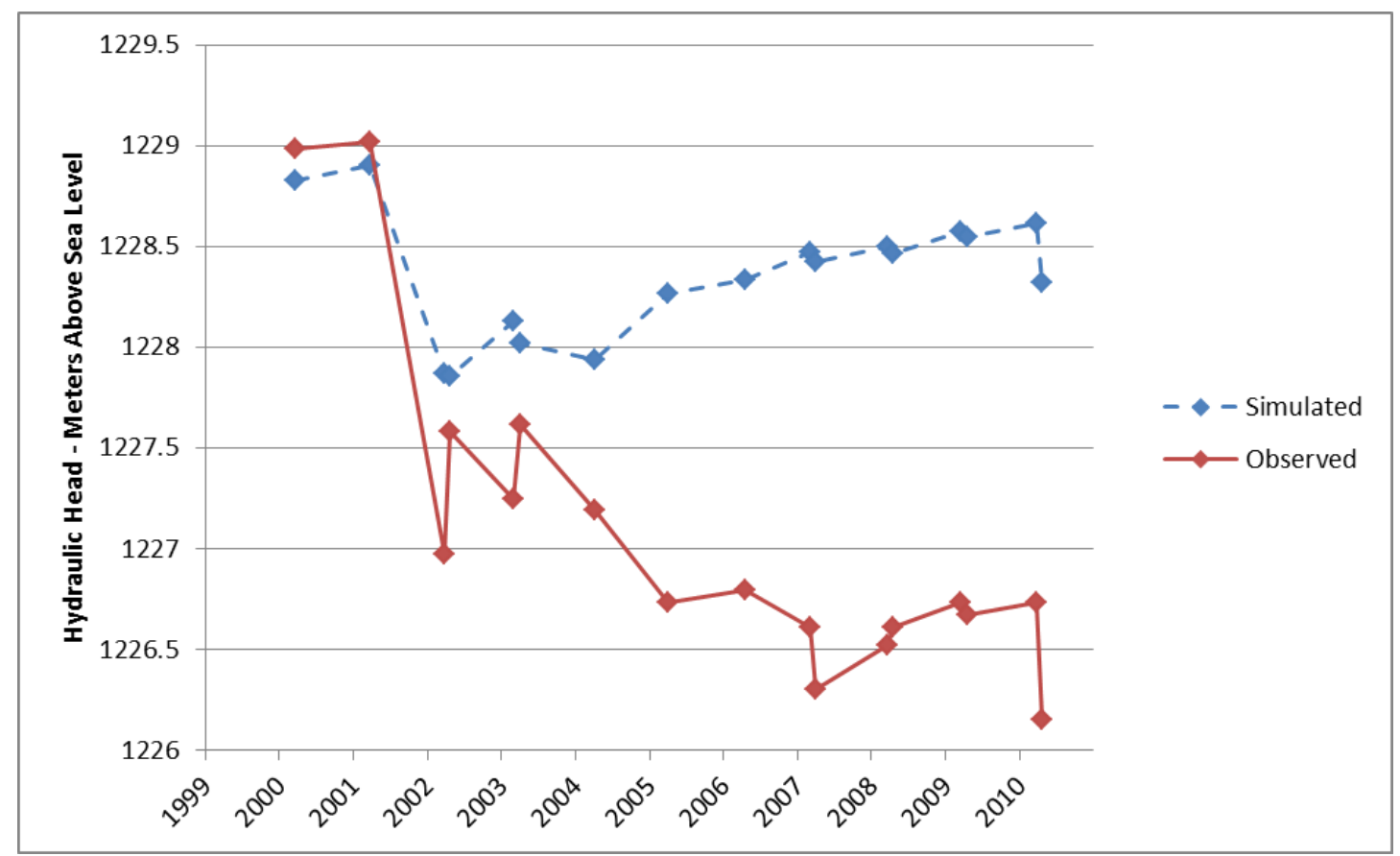

Figure 53. Observed and simulated water-level elevations in CDWR well 48N04E31M001M (Observation Well 34)

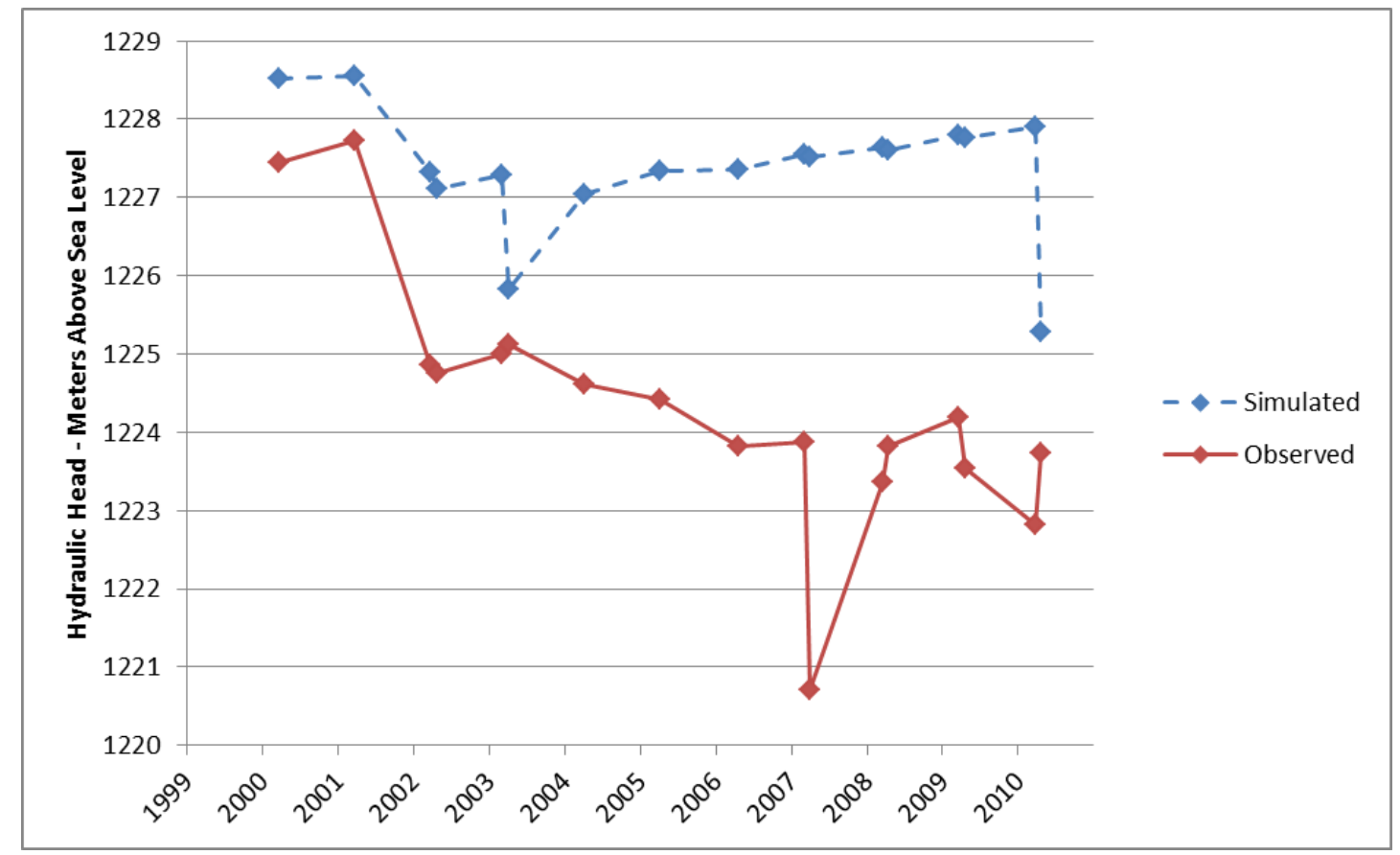

Figure 54. Observed and simulated water-level elevations in CDWR well 48N04E31N002M (Observation Well 35) 


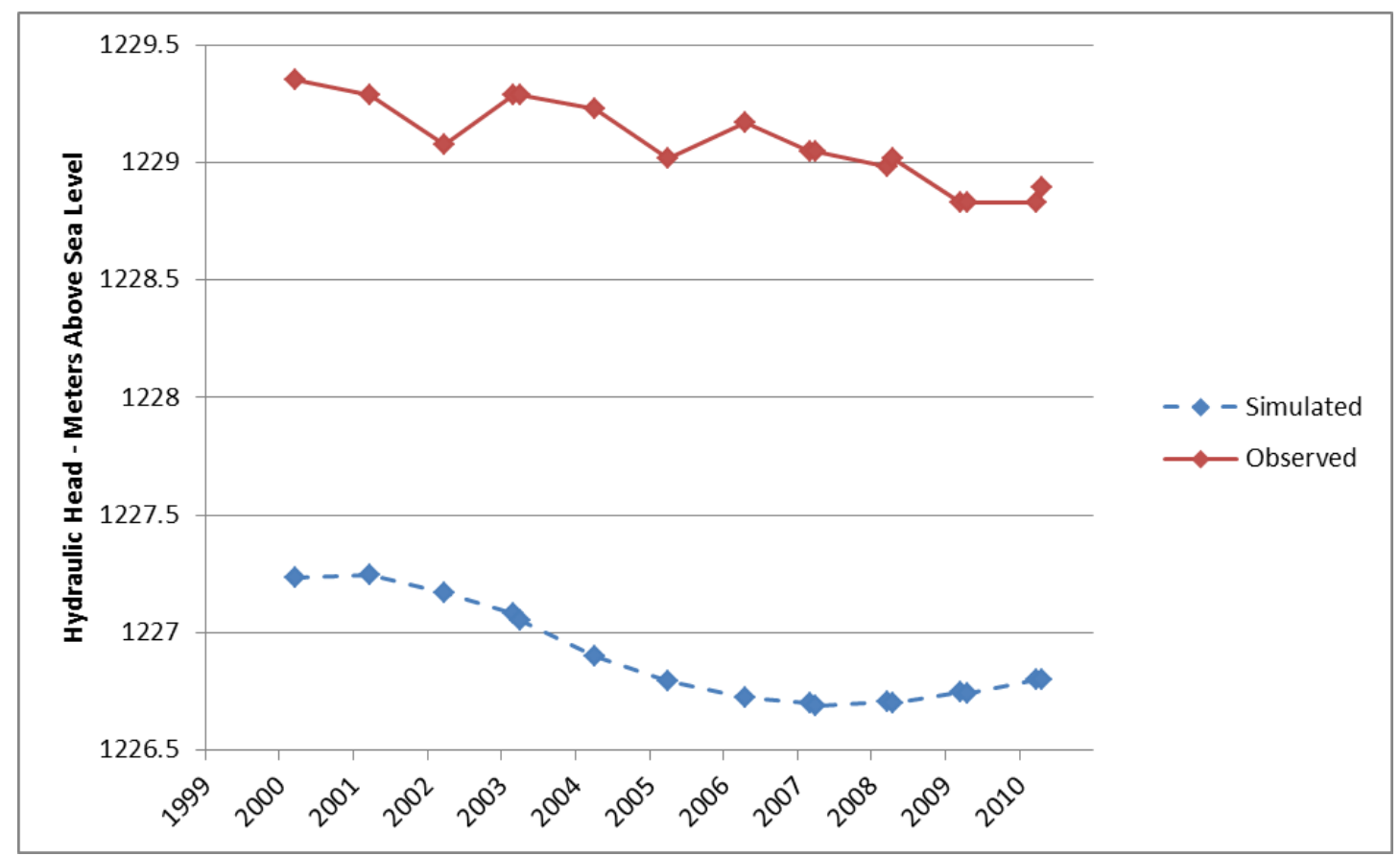

Figure 55. Observed and simulated water-level elevations in CDWR well 48N04E35G001M (Observation Well 36)

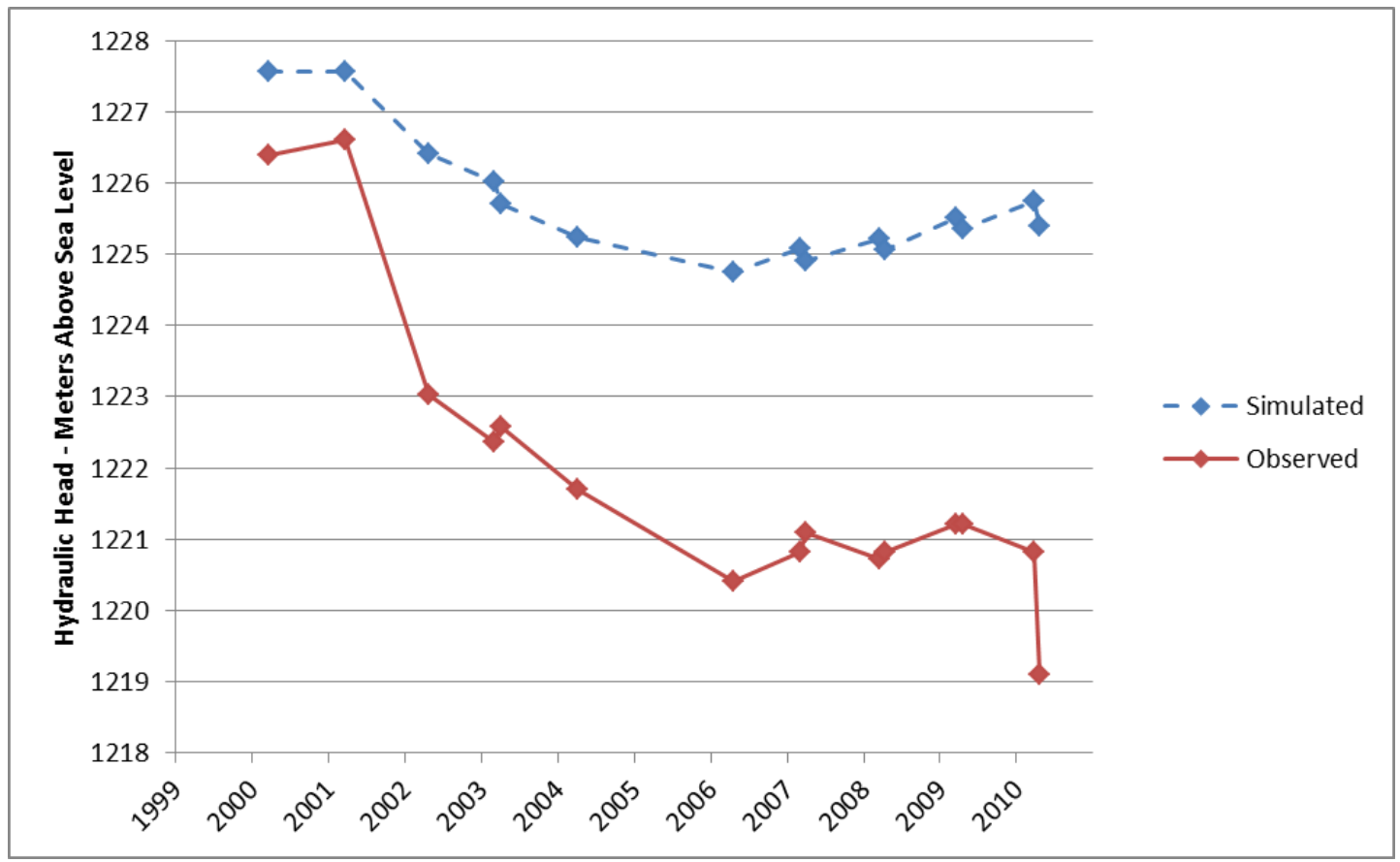

Figure 56. Observed and simulated water-level elevations in CDWR well 48N04E35L002M (Observation Well 37) 


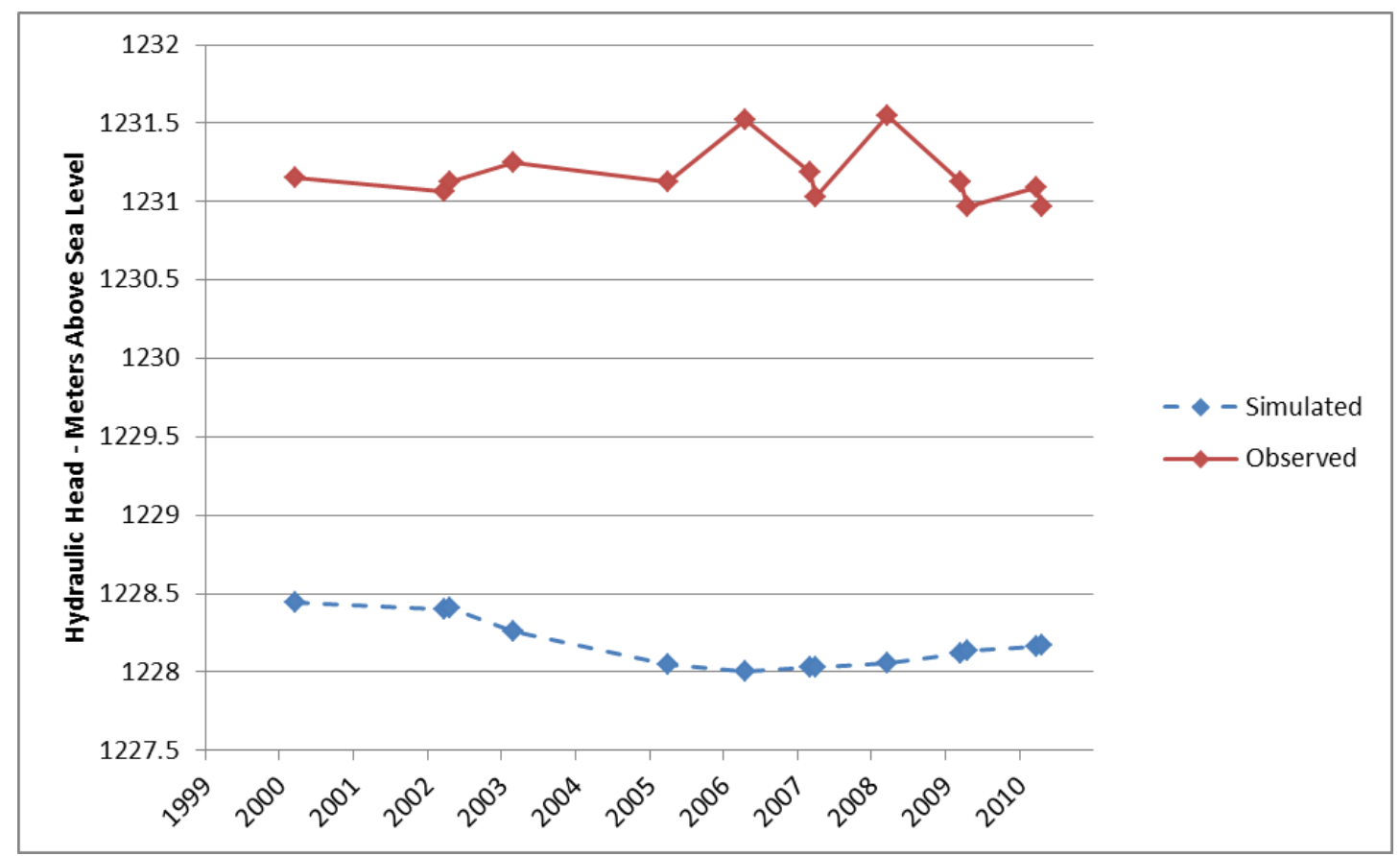

Figure 57. Observed and simulated water-level elevations in CDWR well 48N05E22L001M (Observation Well 38)

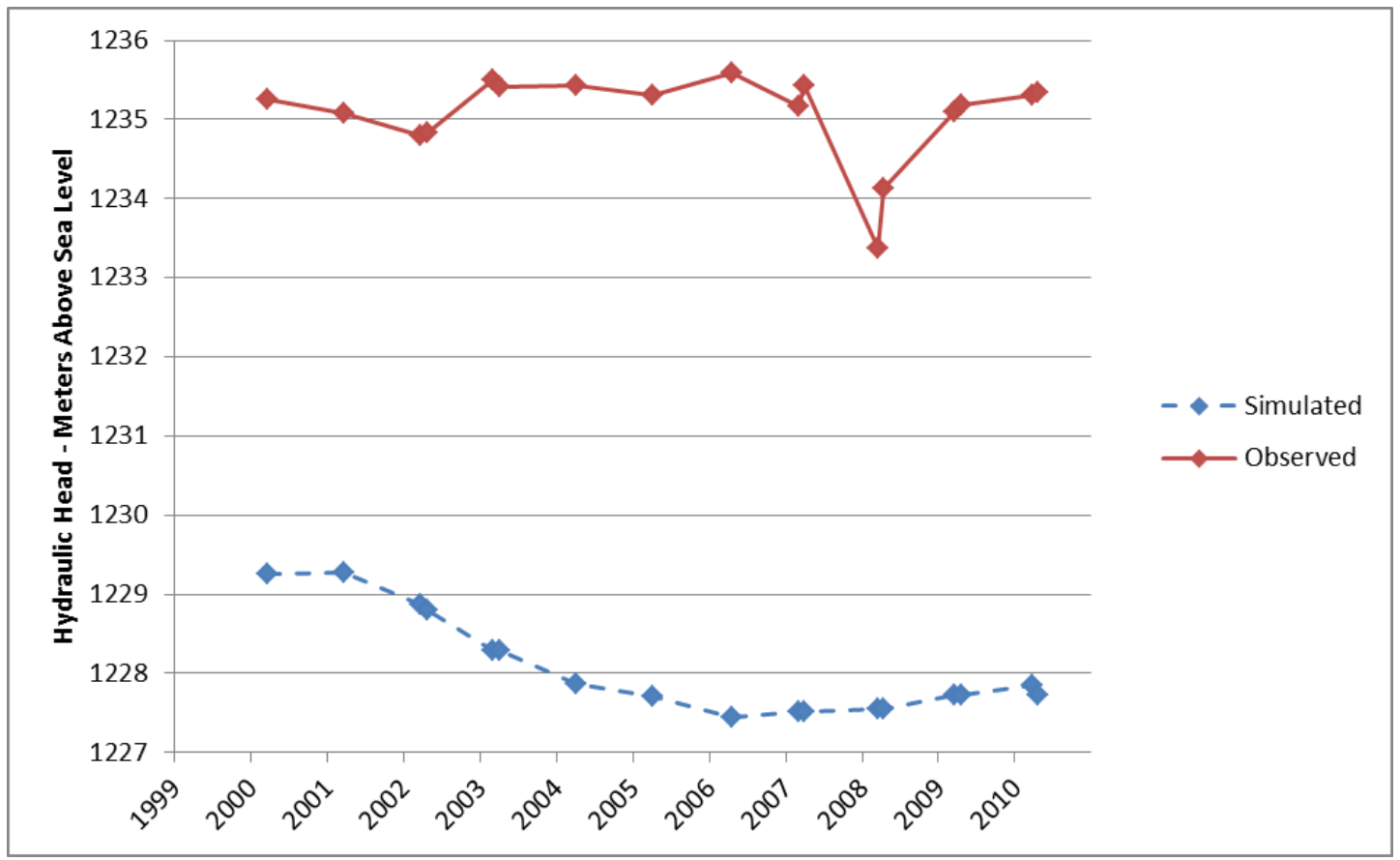

Figure 58. Observed and simulated water-level elevations in CDWR well 48N05E24P001M (Observation Well 39) 


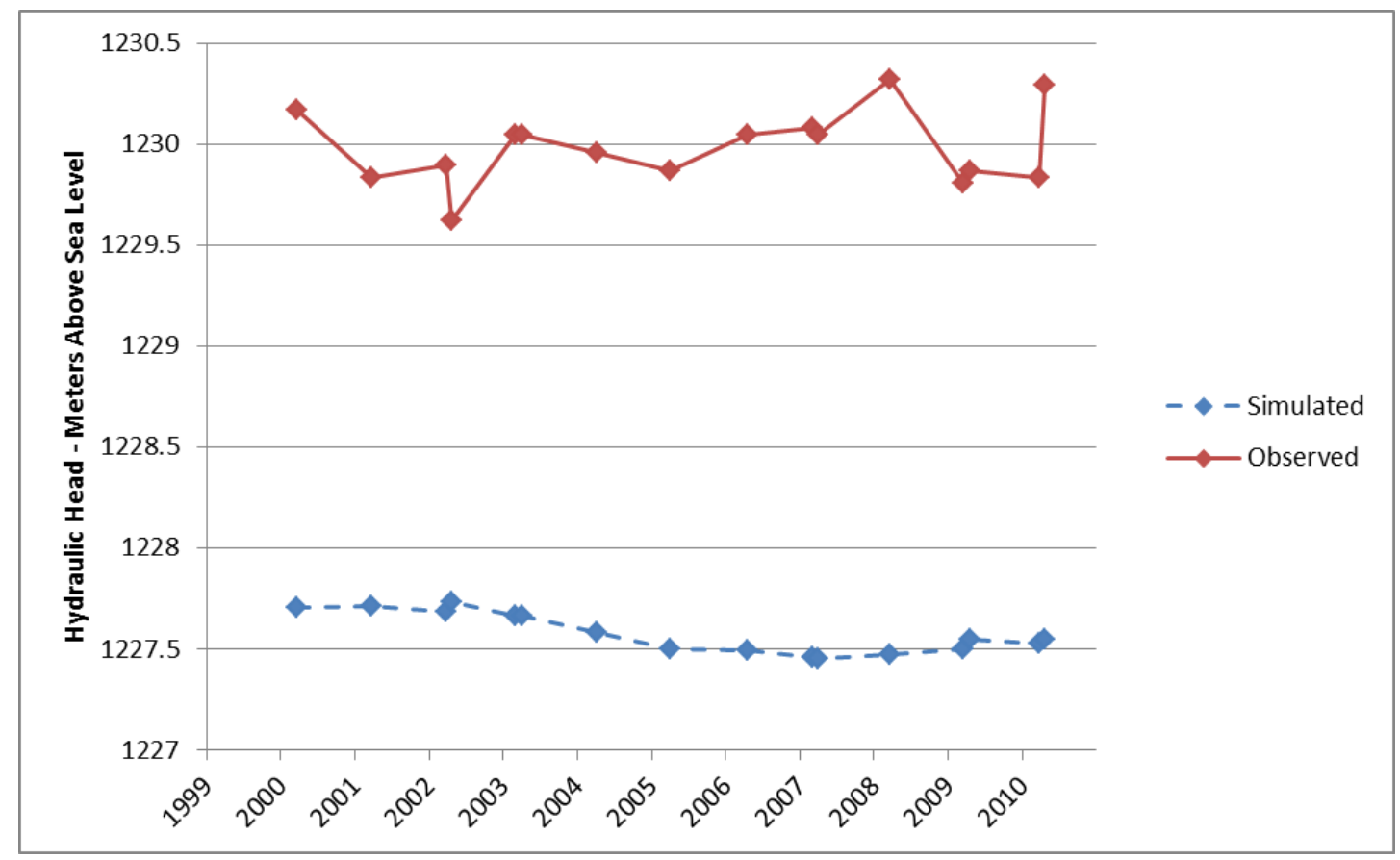

Figure 59. Observed and simulated water-level elevations in CDWR well 48N05E33H001M (Observation Well 40)

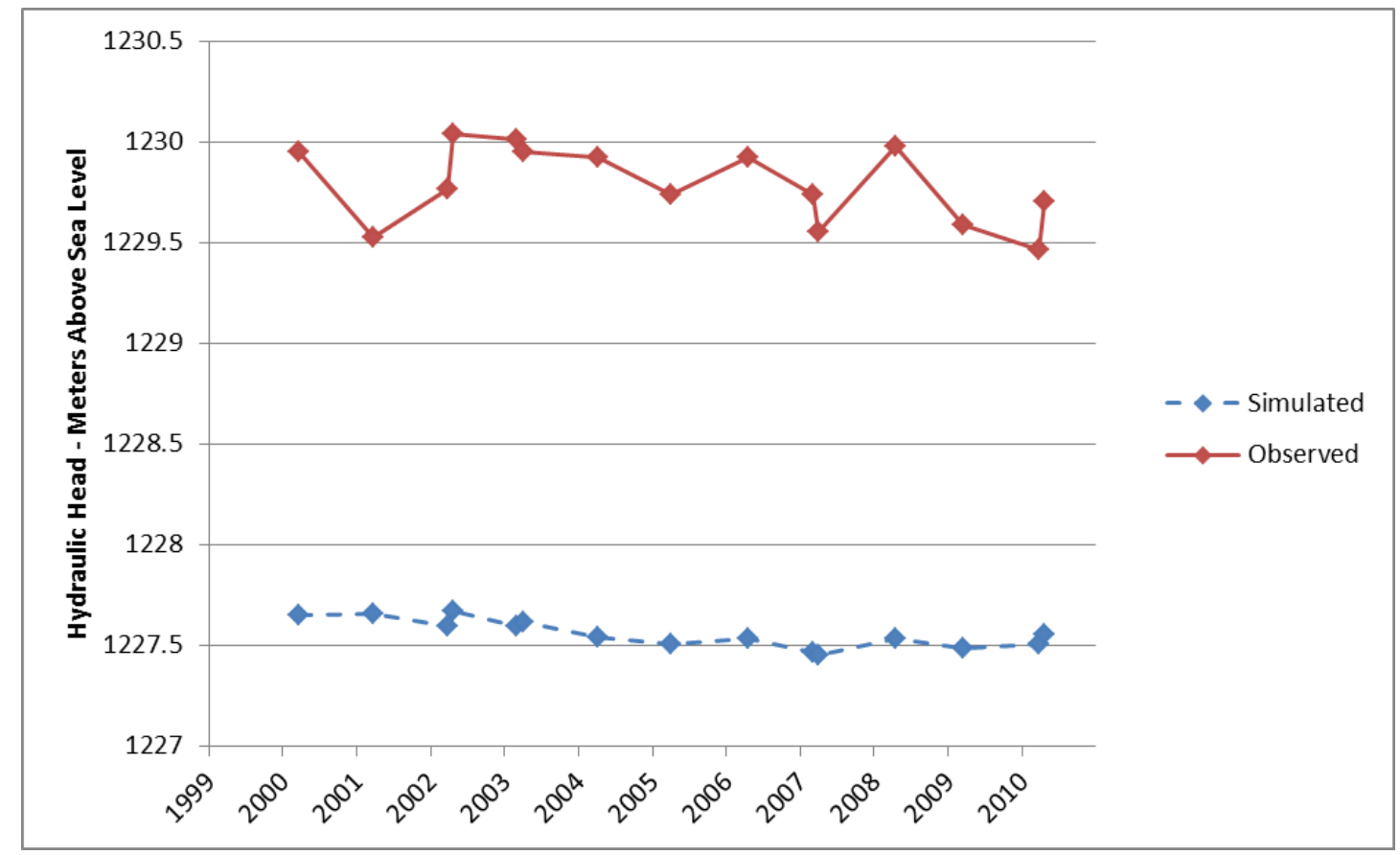

Figure 60. Observed and simulated water-level elevations in CDWR well 48N05E35F001M (Observation Well 41) 


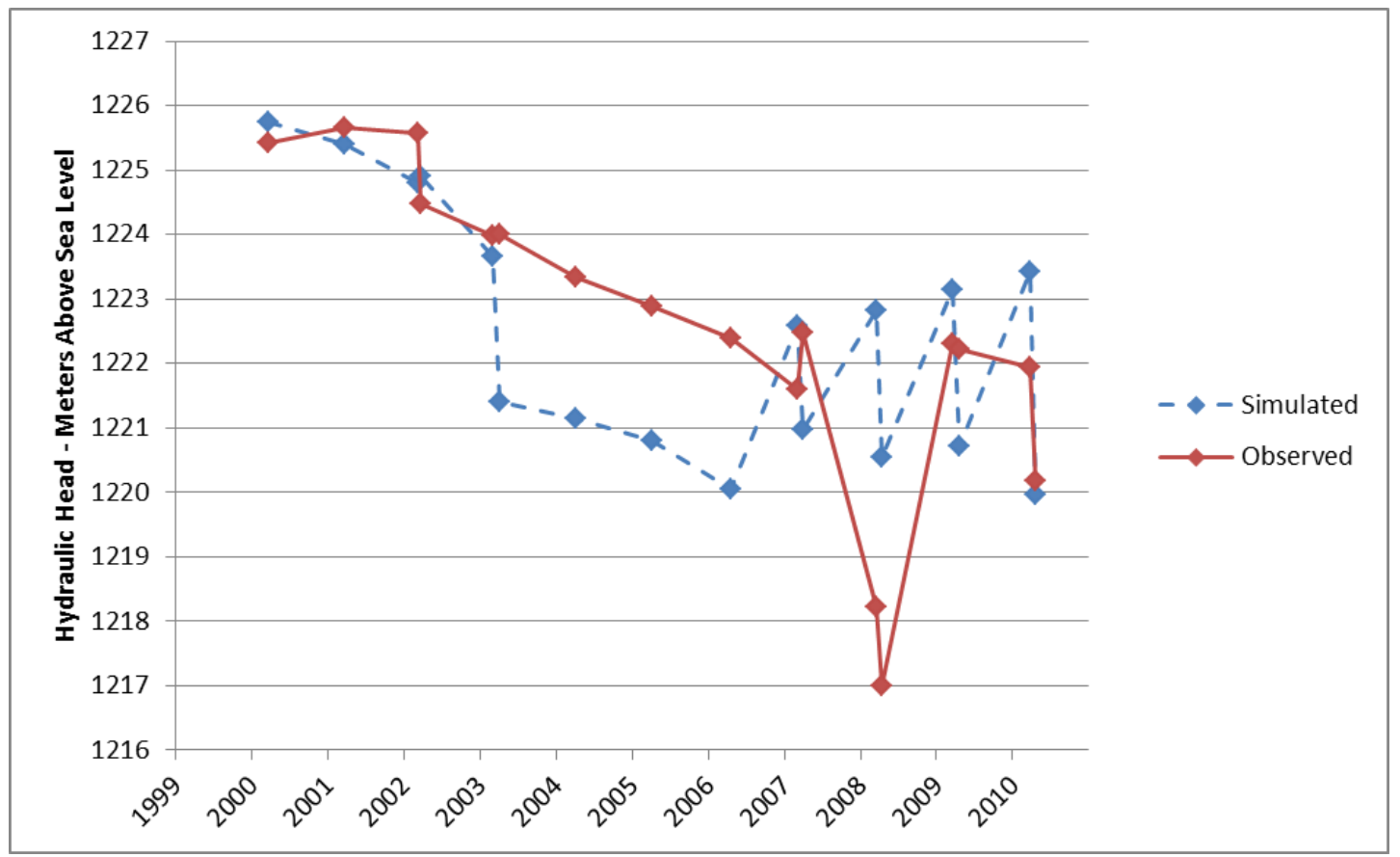

Figure 61. Observed and simulated water-level elevations in CDWR well 48N05E36A002M (Observation Well 42) 
Appendix B: Supplemental Files 
Table 5 provides the name, file type, and size of each file required to run the Tule Lake subbasin groundwater model. In order for the model to run successfully, the files must be organized in a particular structure, as diagrammed below. Filenames within the topmost file (Grid_Arrays, Pumpage, Rch_Arrays, Res_Arrays) must be named as shown here.

- Topmost file (to be named at user's discretion)

- Grid_Arrays

- bot_layer_1.txt through bot_layer_12.txt

- ET_Zones.txt

- LAY1_GEOL.txt through LAY12_GEOL.txt

- top_layer_1.txt

- tule_ibound_3.txt

- Pumpage

- Pumping_2000f.txt through Pumping_2010w.txt

- Pumping_SS.txt

- Rch_Arrays

- tule_canal_rch_array.txt

- tule_rcharray_197912.txt

- tule_rcharray_198003.txt

- tule_rcharray_198006.txt

- tule_rcharray_198009.txt

- tule_ss_rch_array.txt

- Res_Arrays

- tule_bres.txt

- tule_hcres.txt

- tule_ires.txt

- name.txt

- tule_bas_tulelake.txt

- tule_drn_4025.txt

- tule_ghb_tr_new.txt

- tule_hobs_tr_itt1_spr2.txt

- tule_hydmod_newgrid.txt

- tule_lpf2_tr.txt

- tule_mult_drt.txt

- tule_obs.txt

- tule_oc.txt

- tule_pcg.txt

- tule_pes.txt

- tule_rch_tr2.txt

- tule_res_tr.txt

- tule_riv_3_tr.txt

- tule_sen_10-28-13.txt

- tule_start_head_batch_spinup.bin

- tule_wel2.txt

- tule_zones.txt 
Table 5. List of supplemental files.

\begin{tabular}{|c|c|c|c|}
\hline Name & File Type & Size & $\begin{array}{c}\text { Required application } \\
\text { software }\end{array}$ \\
\hline bot_layer_1 & TXT & $55 \mathrm{~KB}$ & MODFLOW-2000 \\
\hline bot_layer_2 & TXT & $55 \mathrm{~KB}$ & MODFLOW-2000 \\
\hline bot_layer_3 & TXT & $55 \mathrm{~KB}$ & MODFLOW-2000 \\
\hline bot_layer_4 & TXT & $55 \mathrm{~KB}$ & MODFLOW-2000 \\
\hline bot_layer_5 & TXT & $55 \mathrm{~KB}$ & MODFLOW-2000 \\
\hline bot_layer_6 & TXT & $55 \mathrm{~KB}$ & MODFLOW-2000 \\
\hline bot_layer_7 & TXT & $55 \mathrm{~KB}$ & MODFLOW-2000 \\
\hline bot_layer_8 & TXT & $55 \mathrm{~KB}$ & MODFLOW-2000 \\
\hline bot_layer_9 & TXT & $55 \mathrm{~KB}$ & MODFLOW-2000 \\
\hline bot_layer_10 & TXT & $55 \mathrm{~KB}$ & MODFLOW-2000 \\
\hline bot_layer_11 & TXT & $55 \mathrm{~KB}$ & MODFLOW-2000 \\
\hline bot_layer_12 & TXT & $55 \mathrm{~KB}$ & MODFLOW-2000 \\
\hline ET_Zones & TXT & $133 \mathrm{~KB}$ & MODFLOW-2000 \\
\hline LAY1_GEOL & TXT & $55 \mathrm{~KB}$ & MODFLOW-2000 \\
\hline LAY2_GEOL & TXT & $55 \mathrm{~KB}$ & MODFLOW-2000 \\
\hline LAY3_GEOL & TXT & $55 \mathrm{~KB}$ & MODFLOW-2000 \\
\hline LA Y4_GEOL & TXT & $55 \mathrm{~KB}$ & MODFLOW-2000 \\
\hline LAY5_GEOL & TXT & $55 \mathrm{~KB}$ & MODFLOW-2000 \\
\hline LAY6_GEOL & TXT & $55 \mathrm{~KB}$ & MODFLOW-2000 \\
\hline LAY7_GEOL & TXT & $55 \mathrm{~KB}$ & MODFLOW-2000 \\
\hline LAY8_GEOL & TXT & $55 \mathrm{~KB}$ & MODFLOW-2000 \\
\hline LAY9_GEOL & TXT & $55 \mathrm{~KB}$ & MODFLOW-2000 \\
\hline LAY10_GEOL & TXT & $55 \mathrm{~KB}$ & MODFLOW-2000 \\
\hline LAY11_GEOL & TXT & $55 \mathrm{~KB}$ & MODFLOW-2000 \\
\hline LAY12_GEOL & TXT & $55 \mathrm{~KB}$ & MODFLOW-2000 \\
\hline top_layer_1 & TXT & $55 \mathrm{~KB}$ & MODFLOW-2000 \\
\hline tule_ibound_3 & TXT & $17 \mathrm{~KB}$ & MODFLOW-2000 \\
\hline Pumping_2000f & TXT & $19 \mathrm{~KB}$ & MODFLOW-2000 \\
\hline Pumping_2000sm & TXT & $19 \mathrm{~KB}$ & MODFLOW-2000 \\
\hline Pumping_2000sp & TXT & $19 \mathrm{~KB}$ & MODFLOW-2000 \\
\hline Pumping_2000w & TXT & $19 \mathrm{~KB}$ & MODFLOW-2000 \\
\hline Pumping_2001f & TXT & $19 \mathrm{~KB}$ & MODFLOW-2000 \\
\hline Pumping_2001sm & TXT & $19 \mathrm{~KB}$ & MODFLOW-2000 \\
\hline Pumping_2001sp & TXT & $19 \mathrm{~KB}$ & MODFLOW-2000 \\
\hline
\end{tabular}


Table 5, continued.

\begin{tabular}{|c|c|c|c|}
\hline Name & File Type & Size & $\begin{array}{c}\text { Required application } \\
\text { software }\end{array}$ \\
\hline Pumping_2001w & TXT & $19 \mathrm{~KB}$ & MODFLOW-2000 \\
\hline Pumping_2002f & TXT & $19 \mathrm{~KB}$ & MODFLOW-2000 \\
\hline Pumping_2002sm & TXT & $19 \mathrm{~KB}$ & MODFLOW-2000 \\
\hline Pumping_2002sp & TXT & $19 \mathrm{~KB}$ & MODFLOW-2000 \\
\hline Pumping_2002w & TXT & $22 \mathrm{~KB}$ & MODFLOW-2000 \\
\hline Pumping_2003f & TXT & $19 \mathrm{~KB}$ & MODFLOW-2000 \\
\hline Pumping_2003sm & TXT & $19 \mathrm{~KB}$ & MODFLOW-2000 \\
\hline Pumping_2003sp & TXT & $19 \mathrm{~KB}$ & MODFLOW-2000 \\
\hline Pumping_2003w & TXT & $19 \mathrm{~KB}$ & MODFLOW-2000 \\
\hline Pumping_2004f & TXT & $19 \mathrm{~KB}$ & MODFLOW-2000 \\
\hline Pumping_2004sm & TXT & $19 \mathrm{~KB}$ & MODFLOW-2000 \\
\hline Pumping_2004sp & TXT & $19 \mathrm{~KB}$ & MODFLOW-2000 \\
\hline Pumping_2004w & TXT & $19 \mathrm{~KB}$ & MODFLOW-2000 \\
\hline Pumping_2005f & TXT & $19 \mathrm{~KB}$ & MODFLOW-2000 \\
\hline Pumping_2005sm & TXT & $19 \mathrm{~KB}$ & MODFLOW-2000 \\
\hline Pumping_2005sp & TXT & $19 \mathrm{~KB}$ & MODFLOW-2000 \\
\hline Pumping_2005w & TXT & $19 \mathrm{~KB}$ & MODFLOW-2000 \\
\hline Pumping_2006f & TXT & $19 \mathrm{~KB}$ & MODFLOW-2000 \\
\hline Pumping_2006sm & TXT & $19 \mathrm{~KB}$ & MODFLOW-2000 \\
\hline Pumping_2006sp & TXT & $19 \mathrm{~KB}$ & MODFLOW-2000 \\
\hline Pumping_2006w & TXT & $19 \mathrm{~KB}$ & MODFLOW-2000 \\
\hline Pumping_2007f & TXT & $19 \mathrm{~KB}$ & MODFLOW-2000 \\
\hline Pumping_2007sm & TXT & $19 \mathrm{~KB}$ & MODFLOW-2000 \\
\hline Pumping_2007sp & TXT & $19 \mathrm{~KB}$ & MODFLOW-2000 \\
\hline Pumping_2007w & TXT & $19 \mathrm{~KB}$ & MODFLOW-2000 \\
\hline Pumping_2008f & TXT & $19 \mathrm{~KB}$ & MODFLOW-2000 \\
\hline Pumping_2008sm & TXT & $19 \mathrm{~KB}$ & MODFLOW-2000 \\
\hline Pumping_2008sp & TXT & $19 \mathrm{~KB}$ & MODFLOW-2000 \\
\hline Pumping_2008w & TXT & $19 \mathrm{~KB}$ & MODFLOW-2000 \\
\hline Pumping_2009f & TXT & $19 \mathrm{~KB}$ & MODFLOW-2000 \\
\hline Pumping_2009sm & TXT & $19 \mathrm{~KB}$ & MODFLOW-2000 \\
\hline Pumping_2009sp & TXT & $19 \mathrm{~KB}$ & MODFLOW-2000 \\
\hline Pumping_2009w & TXT & $19 \mathrm{~KB}$ & MODFLOW-2000 \\
\hline
\end{tabular}


Table 5, continued.

\begin{tabular}{|c|c|c|c|}
\hline Name & File Type & Size & $\begin{array}{c}\text { Required application } \\
\text { software }\end{array}$ \\
\hline Pumping_2010f & TXT & $19 \mathrm{~KB}$ & MODFLOW-2000 \\
\hline Pumping_2010sm & TXT & $19 \mathrm{~KB}$ & MODFLOW-2000 \\
\hline Pumping_2010sp & TXT & $19 \mathrm{~KB}$ & MODFLOW-2000 \\
\hline Pumping_2010w & TXT & $23 \mathrm{~KB}$ & MODFLOW-2000 \\
\hline Pumping_SS & TXT & $19 \mathrm{~KB}$ & MODFLOW-2000 \\
\hline tule_canal_rch_array & TXT & $18 \mathrm{~KB}$ & MODFLOW-2000 \\
\hline tule_rcharray_197912 & TXT & $55 \mathrm{~KB}$ & MODFLOW-2000 \\
\hline tule_rcharray_198003 & TXT & $55 \mathrm{~KB}$ & MODFLOW-2000 \\
\hline tule_rcharray_198006 & TXT & $55 \mathrm{~KB}$ & MODFLOW-2000 \\
\hline tule_rcharray_198009 & TXT & $55 \mathrm{~KB}$ & MODFLOW-2000 \\
\hline tule_ss_rch_array & TXT & $55 \mathrm{~KB}$ & MODFLOW-2000 \\
\hline tule_bres & TXT & $55 \mathrm{~KB}$ & MODFLOW-2000 \\
\hline tule_hcres & TXT & $55 \mathrm{~KB}$ & MODFLOW-2000 \\
\hline tule_ires & TXT & $55 \mathrm{~KB}$ & MODFLOW-2000 \\
\hline name & TXT & $2 \mathrm{~KB}$ & MODFLOW-2000 \\
\hline tule_bas_tulelake & TXT & $2 \mathrm{~KB}$ & MODFLOW-2000 \\
\hline tule_drn_4025_tr & TXT & $129 \mathrm{~KB}$ & MODFLOW-2000 \\
\hline tule_ghb_tr_new & TXT & $224 \mathrm{~KB}$ & MODFLOW-2000 \\
\hline tule_hobs_tr_itt1_spr2 & TXT & $29 \mathrm{~KB}$ & MODFLOW-2000 \\
\hline tule_hydmod_newgrid & TXT & $5 \mathrm{~KB}$ & MODFLOW-2000 \\
\hline tule_lpf2_tr & TXT & $8 \mathrm{~KB}$ & MODFLOW-2000 \\
\hline tule_mult_drt & TXT & $9 \mathrm{~KB}$ & MODFLOW-2000 \\
\hline tule_obs & TXT & $1 \mathrm{~KB}$ & MODFLOW-2000 \\
\hline tule_oc & TXT & $1 \mathrm{~KB}$ & MODFLOW-2000 \\
\hline tule_pcg & TXT & $1 \mathrm{~KB}$ & MODFLOW-2000 \\
\hline tule_pes & TXT & $1 \mathrm{~KB}$ & MODFLOW-2000 \\
\hline tule_rch_tr2 & TXT & $4 \mathrm{~KB}$ & MODFLOW-2000 \\
\hline tule_res_tr & TXT & $10 \mathrm{~KB}$ & MODFLOW-2000 \\
\hline tule_riv_3_tr & TXT & $14 \mathrm{~KB}$ & MODFLOW-2000 \\
\hline tule_sen_10-28-13 & TXT & $2 \mathrm{~KB}$ & MODFLOW-2000 \\
\hline tule_start_head_batch_spinup & BIN & $708 \mathrm{~KB}$ & MODFLOW-2000 \\
\hline tule_wel2 & TXT & $9 \mathrm{~KB}$ & MODFLOW-2000 \\
\hline tule_zones & TXT & $2 \mathrm{~KB}$ & MODFLOW-2000 \\
\hline
\end{tabular}

